\title{
How Does Private Firm Disclosure Affect Demand for Public Firm Equity? Evidence from the Global Equity Market
}

\author{
August 2021
}

\begin{abstract}
We investigate the relationship between private firms' disclosures and the demand for the equity of their publicly traded peers. Using data on the global movement of public equity, we find that a one standard deviation increase in private firm disclosure transparency - proxied by the number of disclosed private firms' financial statement line items - reduces global investors' demand for public equity by $11 \%$ to $12 \%$ or $\$ 174$ million to $\$ 190$ million in dollar terms. These findings are consistent with private firm disclosures generating negative pecuniary externalities - global investors reallocate their capital away from public firms to more transparent private firms - and less consistent with these disclosures creating positive information externalities that would benefit public firms. Consistent with this interpretation, we find that the reduction in demand for public equity is offset by a comparable increase in capital allocation to more transparent private firms. Using staggered openings of the Bureau van Dijk database offices and implementation of electronic business registers in investee countries as plausibly exogenous shocks to private firm transparency, we conclude that the negative relationship between private firm disclosures and public equity demand is likely causal.
\end{abstract}

Key words: Private firm disclosures, global capital, disclosure externalities, pecuniary externalities

JEL codes: F21, F30, G15, G30, M16, M40, M41 


\section{INTRODUCTION}

We study the effects of private firm disclosure on the demand for public firm equity by global investors. In 2020, over $98 \%$ of the 40 million firms that disclosed detailed financial statement information worldwide were privately owned (World Bank (2020); Bureau van Dijk (2020)). Given their economic importance, the social value (or cost) of regulating private firm disclosures is likely significant, and the extent to which to regulate these disclosures has been a central topic of debate among regulators (Minnis and Shroff (2017); Lisowsky and Minnis (2020)). Key to informing this debate is understanding the potential spillover effects of these disclosures (Leuz and Wysocki (2016)). While emerging research has made progress in investigating both the determinants and firm-level costs and benefits of private firm disclosures, relatively little is known about the spillover effects of these disclosures (Bernard (2016); Breuer (2021)). ${ }^{1,2}$ We extend this literature by examining an important but underexplored spillover effect - whether and how private firm disclosures impact investor demand for equity of their publicly traded peers.

The impact of private firm disclosures on the demand for public firm equity is theoretically ambiguous. It depends critically on assumptions about whether private firm disclosures are primarily idiosyncratic - providing information specifically about private firms themselves (e.g., Bushman, Piotroski, and Smith (2004); Davila and Korinek (2016)) - or industry wide - generating information relevant for evaluating public peers in the same industry (e.g., Badertscher, Shroff, and White (2013); Kim, Verdi, and Yost (2020); Bernard, Blackburne, and Thornock (2020);

\footnotetext{
${ }^{1}$ We use the terms spillovers and externalities interchangeably. As discussed further below, in our context, we examine two types of disclosure spillovers or externalities - the first being negative pecuniary externalities, which describes the possibility that private firm disclosures can induce redistribution of capital away from public firms (e.g., Davila and Korinek (2016)), whereas the second being positive information externalities, which means that private firm disclosures can help reduce informational uncertainty about public peer firms and help them attract more capital.

${ }^{2}$ Other examples of studies in this area include Ball and Shivakumar (2005); Dedman and Lennox (2009); Minnis (2011); Shroff (2016); Bernard, Burgstahler, and Kaya (2018); Gassen and Muhn (2018); Baik, Berfeld, and Verdi (2020); Breuer and Breuer (2020); Breuer, Hombach, and Muller (2020); Glaeser and Omartian (2021).
} 
Bernard, Kaya, and Wertz (2020); Barrios, Choi, Hochberg, Kim, and Liu (2021)). If private firm disclosures are primarily idiosyncratic, they will likely reduce investors' uncertainty specifically about the private firms' value and induce investors to reallocate more of their capital to private firms away from public firms, ceteris paribus. ${ }^{3}$ On the other hand, if private firm disclosures are more industry wide, the reduction in uncertainty regarding the value of public firms will be greater and may increase demand for public equity. Thus, the effect of private firm disclosures on the demand for public equity will depend on which of these two forces is dominant. ${ }^{4}$

To estimate variation in private firm disclosures, we develop a novel measure applicable to a broad cross-section of countries and industries using Bureau van Dijk's (BvD) Orbis database for the period 2003 to 2017. Specifically, similar in spirit to Chen, Miao, and Shevlin (2015), we divide the number of financial statement line items that private firms disclose by the total number of line items that these private firms can hypothetically disclose. For example, in 2013 we observe private firms in Japan's manufacturing industry disclosed 89\%, on average, of their financial statement line items relative to the hypothetical full disclosure, whereas private firms in Germany's manufacturing industry disclosed only $68 \%$ on average ${ }^{5}$ Our measure suggests that manufacturing private firms in Japan were more transparent than that of Germany in 2013, ceteris paribus. ${ }^{6}$

\footnotetext{
${ }^{3}$ Another important underlying assumption is that investors are risk averse and have limited capital, inducing them to reallocate their capital to make new investments (Stiglitz (1981); Siriwardane (2019)). Consistent with this idea, we show our findings are more pronounced in settings where investors are likely capital constrained.

${ }^{4}$ We implicitly assume investors have access to both public and private equity and consume financial disclosures. While this may not be true for small retail investors, we find this assumption to be plausible for a variety of investors such as high net worth individuals as well as institutional and corporate investors as discussed in Sections 2 and 3.2.2. ${ }^{5}$ We scale by the hypothetical full disclosure to avoid giving mechanically higher transparency values to investee country-industries with more private firms. We recognize that this approach ignores the total amount of private firm disclosures generated by an investee country-industry. To address this concern, we show in Table 8 that our findings are robust to using the total number of line items disclosed (without scaling), discussed further below. Moreover, we include control variables to address a related concern that the distribution of firm sizes may be driving our results. ${ }^{6}$ We acknowledge that line item disclosures are partly voluntary, and likely endogenous to economic factors such as investment opportunities and financing conditions that can jointly determine public equity demand. Our baseline findings are, thus, not necessarily causal. We exploit an additional setting that likely generated exogenous variation in private firm disclosures, and find evidence consistent with the negative relation being causal in Section 4.
} 
We begin by exploring the relation between private firm disclosures and future demand for public equity using data from the Global Capital Allocation Project (GCAP), which tracks the global movement of public equity across countries. Specifically, the database allows us to observe equity demand of an investor country (investor, for short) for a particular investee countryindustry-year (investee-industry-year, for short). For example, we are able to track US investors' demand for equity of publicly traded firms in Japan's versus Germany's manufacturing industry each year. We use investor-investee-industry-year as our unit of analysis because we expect private firm disclosures to have the strongest impact (either negative or positive) on the demand for public equity of peer firms in the same investee-industry-year. Moreover, we include an investorinvestee-industry fixed effect to reduce the risk of unobserved cross-country heterogeneity driving our results. Specifically, our tests relate the changes of an investor's investment within an investeeindustry to the changes in private firm transparency of the same investee-industry over time.

We find a one standard deviation increase (i.e., a 27 percentage-point increase) in our private firm disclosure measure is associated with a $11 \%$ to $12 \%$ or $\$ 174$ million to $\$ 190$ million decrease in average total future equity demand by foreign investors per investee-industry-year, suggesting that the effect is material. The magnitude seems reasonable when placed in context with Maggiori, Neiman, and Schreger (2020), who show a $42 \%$ decrease in cross-border demand for eurodenominated corporate debt after the financial crisis of $2008 .{ }^{7}$ Our findings are robust to alternative model specifications and to the inclusion of various controls. Moreover, we find that the three subcomponents of our disclosure measure - balance sheet items, income statement items, and

\footnotetext{
${ }^{7}$ Our results are also comparable to Lang, Maffett, Omartian, and Silvers (2020), who document a $12 \%$ increase in investment by both foreign and local funds to US cross-listed firms relative to non-US cross-listed firms in the same country around the signing of the Multilateral Memorandum of Understanding (MMoU), a non-binding, informationsharing arrangement between global securities regulators.
} 
footnote disclosures - individually have significant negative relations with future equity demand. These findings suggest global investors consume various elements of financial statements, shedding new light on the precise type of financial information global investors use when reallocating capital (Ferracuti and Stubben (2019)). Taken together, the negative relation is consistent with private firm disclosures being more idiosyncratic, which leads to an economically significant reduction in the demand for public equity.

A reallocation of capital from public to private firms is implicitly assumed in the argument that private firm disclosures reduce demand for public firm equity. We address this implied relationship in three steps. First, we expect and find the negative link between private firm disclosures and demand for public equity is more pronounced when investors are constrained in their ability to invest new capital in an investee country. Specifically, following prior research, we use each investor-investee pair's strictness in controlling foreign capital flows as a proxy for the investor country's constraints in investing new capital in an investee country. ${ }^{8}$ We document that our capital control proxy is linked to significant additional reductions in public equity demand relative to baseline averages. ${ }^{9}$ This is consistent with capital constraints inducing investors to reallocate their existing capital (i.e., public equity) - rather than injecting new capital - to invest in private firms with transparent financial statement disclosures.

Second, we expect and find the negative link between private firm disclosures and demand for public equity is more pronounced when the investor and investee countries are more "distant" to each other either in terms of language or geographically. This is consistent with private firm

\footnotetext{
${ }^{8}$ We follow Fernández et al. (2016) and Makarov and Schoar (2020) to measure the investor (investee) country's strictness in controlling foreign capital outflow (inflow). In additional tests, we use the investee country's currency appreciation as an alternative measure for the extent to which investors are constrained in investing new capital. A more detailed discussion is in Section 3.

${ }^{9}$ Specifically, we find that being the top decile investor-investee pair in terms of strictness in capital control is linked to a $32.4 \%$ additional reduction in public equity demand relative to baseline averages. See Section 4 for details.
} 
disclosures playing a greater role when information frictions are more severe because of greater distances between countries (Lang, Maffett, Omartian, and Silvers (2020)). Specifically, we use principal component analysis to summarize the various measures of language and geographic distances provided by the CEPII data, and create composite language and geographic distance measures for each investor-investee pair (see Section 4.2). We show that our distance proxies are linked to significant additional reductions in public equity demand. These findings corroborate the inference that investors facing greater informational frictions benefit the most from private firm disclosures, and thus reallocate more capital towards private firms away from public firms. ${ }^{10}$

Third, we find that investee-industries that experience the most significant reduction in public equity demand by global investors are indeed the ones that experience the greatest inflow of foreign capital into private firms. Specifically, we find that a one standard deviation increase in our private firm disclosure proxy is associated with a $12 \%$ to $27 \%$ increase in M\&A and VC activity by global investors targeting the investee country's private firms. Moreover, consistent with reallocation of capital from public to private firms driving our results, we do not find this relation to exist among M\&A activity that targets public firms. Taken together, the results from these additional tests are difficult to fully explain absent a reallocation effect, raising the bar for omitted factors to be the sole driver of our results.

To further shed light on which private firms - the disclosing private firm versus its private firm peers - specifically benefit from the reallocation of capital, we conduct a firm-level analysis. We find evidence consistent with both the disclosing private firm and its private firm peers benefiting from the reallocation. Specifically, we find a positive link between private firm transparency and

\footnotetext{
${ }^{10}$ On the other hand, these findings are less consistent with an omitted correlated variable explaining our result. That is, we expect an omitted correlated variable to play a weaker role among more distant countries because a common unmodelled shock is less likely to affect countries that are more distant to one another.
} 
the future likelihood of the disclosing firm being an M\&A target by foreign investors. In economic terms, a one standard deviation increase in our firm-specific measure of private firm transparency is linked to a 7\% greater likelihood of the disclosing private firm being an M\&A target in the future. Moreover, in stark contrast to the documented negative pecuniary externalities of private firm disclosures on public firms, we find evidence consistent with private firm disclosures generating positive information externalities that benefit other private firms who also become more likely M\&A targets by foreign investors.

While our collective evidence is consistent with private firm disclosures attracting capital away from public firms, this relationship is not necessarily causal. For example, our findings may be explained by reverse causality if private firms collectively increase disclosures in anticipation of (and therefore to attract) the capital outflows from public equities in their industry. Moreover, a country's regulatory choices or private firms' managerial discretion could jointly determine greater private firm disclosures and lower public equity investments (Bernard et al. (2016)). To identify a causal relationship between private firm disclosures and public equity demand, we use staggered openings of the BvD global offices and the implementation of electronic business registers in investee countries as plausibly exogenous shocks to private firm transparency. ${ }^{11}$

When a BvD office opens in a country it collects, standardizes, and provides useful private firm data of the country to investors around the world. BvD databases are the leading source among investors when making investment decisions about investing in foreign countries (Business Wire (2020)). Thus, BvD office openings represent a significant expansion in the availability of private firm information to potential investors in other countries. ${ }^{12}$ Specifically, using LinkedIn data to

\footnotetext{
${ }^{11} \mathrm{We}$ also employ a distributed lag model to alleviate concerns related to reverse causality in Section 4.4.

${ }^{12} \mathrm{We}$ find that BvD office openings in a given investee country are primarily driven by observable investee domestic factors (e.g., a positive relation with GDP). While this suggests the office openings are not strictly random, as we
} 
identify investee-specific years of BvD office openings to generate an exogenous expansion in private firm transparency, we find that a $\mathrm{BvD}$ office opening is linked to a difference-in-differences effect of 32.3\% or $\$ 512$ million decrease in public equity demand by foreign investors after a BvD office opens in an investee country compared to investee countries that did not open a BvD office yet. Similarly, we exploit the implementation of electronic business registers in Europe. The implementation of these business registers represents European countries' effort to reduce the costs of private firms to comply with accounting regulation, facilitate the dissemination of private firm information (similar to that of the EDGAR implementation that took place the US), and impose stricter enforcement of private firm disclosure mandates (Breuer and Breuer (2020)). Using the business registers as a setting, we document a difference-in-differences effect of $22.4 \%$ or $\$ 355$ million decrease in public equity demand after an investee country implements the electronic business register compared to investee countries that did not implement the register yet. These results suggest the documented negative association between private firm disclosures and demand for public equity is likely causal. The documented magnitudes seem reasonable when compared to Breuer and Breuer (2020) that show a $26 \%$ to $32 \%$ effect on employment using a similar design.

This paper contributes to the literature in several ways. First, it extends the emerging literature on the economic consequences of private firm disclosures. While recent studies in this area highlight both the determinants and consequences of private firm disclosures, fewer studies have investigated the externality or aggregate effects of private firm disclosures (e.g., Bernard et al. (2020); Breuer (2021)). We contribute to this underexplored area by showing that private firm disclosures have significant negative pecuniary externalities on the demand for public firm equity.

further articulate in Section 4, we argue that these covariates unlikely explain the negative relation between private firm disclosure and future global public equity demand. 
By doing so, we also contribute to the disclosure spillover literature, which has primarily focused on the informational transfers from public firm disclosures to outside stakeholders such as private firms (Badertscher et al. (2013); Bourveau, Chen, Elfers, and Pierk (2020); Barrios et al. (2021)), but less so on the reverse effect - that private firm disclosures can impact public firm outcomes.

Second, we contribute to the literature that examines the allocation of global capital. How public equity capital moves around the world is a central issue in international policy, especially since many countries have poor domestic capital markets and rely on global capital flows. An emerging literature suggests factors such as cross-border regulatory cooperation (Lang et al. (2020)), governance quality (Leuz, Lins, and Warnock (2009)), home currency bias (Lilley, Maggiori, Neiman, and Schreger (2020)), and exchange rates (Maggiori, Neiman, and Schreger (2020)) affect the movement of global capital. We add to this literature by showing private firm disclosure is an important determinant for the international flow and allocation of public equity capital. By doing so our findings also broadly speak to the literature that investigates the effects of transparency on global capital market outcomes (Gelos and Wei (2005); Piotroski and Srinivasan (2008); Lang and Maffett (2011); De Fond et al. (2011); Lang, Lins, and Maffett (2012); Maffett (2012); Fang, Maffett, and Zhang (2015)).

Third, we contribute to the literature on the measurement of corporate transparency (Dechow et al. (2010)). Unlike the numerous firm-level measures available for publicly traded US firms, there is a dearth of available proxies for private firms, particularly in a global setting. By developing an easily implementable yet widely applicable measure of transparency following Chen et al. (2015), we not only uncover new insights on what information global equity investors consume but also offer a useful tool for future researchers interested in examining the determinants and consequences of private firm disclosures in an international setting. 


\section{BACKGROUND AND HYPOTHESIS}

Our central goal is to examine the relation between private firm disclosures and global investors' demand for public equity. The relation likely depends on two countervailing forces that yield opposing predictions. On the one hand, if private firm disclosures are primarily idiosyncratic, these disclosures will likely generate pecuniary externalities on public firm equity demand by encouraging global investors to reallocate their capital away from public firms to more transparent private firms (e.g., Hart (1975); Stiglitz (1982); Davila and Korinek (2016)). Specifically, investors may prefer to reallocate their capital away from public firms either because the idiosyncratic disclosures of private firms reduce uncertainty and thereby reduce the private firms' cost of capital (French and Poterba (1991); Lang and Maffett (2011)), or because these disclosures can make investors more aware of private firms as viable investment options (Merton (1987)). ${ }^{13}$ The possibility of these scenarios is bolstered by the fact that private firms tend to be small and/or transact with fewer stakeholders such that their disclosures might not generate useful information for other firms but rather remain more firm-specific in nature (Bushman, Piotroski, and Smith (2004); Breuer (2021)).

On the other hand, private firms represent a significant part of the global economy on an aggregate level (World Bank (2020); Minnis and Shroff (2017); Lisowsky and Minnis (2020)). Thus, consistent with country-level corporate transparency attracting public equity capital (Gelos and Wei (2005)), aggregate private firm disclosures (i.e., when aggregated at the investee-industryyear level in our case) might generate useful industry-wide signals that will benefit the valuation

\footnotetext{
${ }^{13}$ More specifically, we expect the relative cost of capital of private firms to be lower than that of public firms when private firm disclosures attract capital away from public firms. While it is the beyond the scope of this paper, one avenue for future research is to explore whether, how, and when private firm disclosures influence the relative cost of capital between public and private firms.
} 
of the private firms' publicly traded peers (Badertscher et al. (2013); Bernard, Blackburne, and Thornock (2020); Barrios et al. (2021); Kim and Valentine (2021)). In this case, private firms' disclosures will generate positive information externalities, which will facilitate the ability of global investors to learn and accurately value public firms, thereby increasing the demand for public equity.

In sum, the net effect of private firm disclosures' effect on the global demand for public equity is theoretically unclear and will depend on whether private firm disclosures are primarily idiosyncratic or industry wide, as stated by our two alternative hypotheses ( $\mathrm{Ha}, \mathrm{Hb})$ :

Ha (negative pecuniary externalities hypothesis): Private firm disclosures will have a negative impact on global public equity demand since the disclosures are primarily idiosyncratic in nature, which induces a reallocation of capital from public firms to more transparent private firms.

Hb (positive information externalities hypothesis): Private firm disclosures will have a positive impact on global public equity demand since the disclosures are primarily industry wide, which facilitates the valuation of public firms, thereby increasing the demand for public firm equity.

Both of our stated hypotheses implicitly assume investors have access to (and optimally allocate across) public and private equity. These hypotheses also assume that investors use private firm financial disclosures when allocating capital between public and private equity. While these assumptions may not be applicable to small retail investors, we find these to be plausible for a variety of investors such as high net worth individuals, institutional investors, and large corporate investors (Investment Company Institute (2020)). ${ }^{14}$ For example, prior research shows that high net worth individuals can significantly impact the equilibrium asset demand because they hold a

\footnotetext{
${ }^{14}$ On the other hand, we find it institutionally less likely for fund managers of individual mutual funds or ETFs to allocate capital across public and private equity at the fund level. This is because investment firms are often constrained or even prohibited from reallocating capital between public and private equity within a fund or an ETF (Gabaix and Koijen (2021)). We thank Scott Richardson for providing this valuable institutional insight on how capital allocation decisions are done in practice.
} 
large fraction of a country's net wealth in both public and private equity (Campbell (2006); Preqin (2020)), and that these individuals use financial statements to make capital allocation decisions (Amel-Zadeh, Lustermans, and Pieterse-Bloem (2021)). Similarly, institutional investors like Berkshire Hathaway and large tech firms like Alphabet Inc. hold significant amounts of both public and private equity through either minority holdings or majority takeovers, and these firms likely have the sophistication to consume financial statement information efficiently (Bernard et al. (2020); Kwon, Lowry, and Qian (2020)). ${ }^{15}$ Finally, information intermediaries can consume and disseminate private firm disclosures and affect investment decisions. Equity analysts regularly talk about competition from private peers when writing reports on their covered public firms. More private firm disclosures can raise awareness or facilitate the analysis of private firm competition, leading analysts to recommend investors to allocate more capital towards certain private firms. ${ }^{16}$

Nevertheless, there are reasons why we might not observe either of our predicted outcomes. First, the two countervailing forces may cancel each other out on average, in which case we wouldn't be able to detect significant statistical relations between private firm disclosures and demand for public equity. Second, certain investors (e.g., retail) may not have the resources, ability, or intention to consume private firm disclosures when making capital allocation decisions.

\footnotetext{
${ }^{15}$ The 2020 10K filings of Berkshire Hathaway Inc. show the diverse equity holdings of Berkshire Hathaway in both public and private firms. Similarly, The $202010 \mathrm{~K}$ filings of Alphabet Inc. show the equity holdings of Alphabet in both public and private firms. Note that GV is Alphabet's subsidiary that focuses on investing in private firms. The chemical conglomerate BASF is another example that invests in public equity of other firms while operating its own venture capital entity that invests in private firms (BASF (2016)).

${ }^{16}$ For example, see Oberhuber (2018). This analyst report discusses how the Swiss food conglomerate Nestle faces increased competition from its private peers, and makes explicit comparisons that can facilitate the reallocation of capital between public and private firms. This is particularly relevant since even mutual funds that traditionally invest in public equity, are also increasingly interested in investing in private firms (Kwon et al. (2020)).
} 


\section{DATA AND RESEARCH DESIGN}

\subsection{Sample Selection and Data}

We construct our sample by combining information on private firm financial disclosures using Bureau van Dijk's (BvD) Orbis database with data on foreign equity portfolio holdings (which we refer to as FPI) from the Global Capital Allocation Project (GCAP) database. ${ }^{17}$ The GCAP database tracks the global movement of public equity across countries and allows us to construct granular measures of foreign equity demand observable at the investor-investee-industry-year level from 2005 to $2017 .{ }^{18}$ For example, we can track US investors' demand for equity of publicly traded firms in the manufacturing industry of Japan versus that of Germany each year.

We use investee countries in the European Economic Area (EAA) as well as other countries around the world with sufficient time-series coverage in the GCAP data. ${ }^{19}$ We then merge the GCAP panel at the investee country-industry-year level to financial reporting data taken from BvD's Orbis database. We retain only investee-industry observations for which firm-level financial reporting data is available in Orbis, i.e., with non-missing values of our independent variable of interest, Transp. \% FS Items (private), defined below. We also require additional variables from $\mathrm{BvD}$, such as the number of private firms, the number of public firms, $\%$ of firms with any financial statement items, and proxies for public firm transparency. This yields a final sample of 73,423 investor-investee-industry-year observations. For definition of variables see Appendix B. Further details on our sample selection procedures are in Table A1 of Appendix C.

\footnotetext{
${ }^{17}$ These data are based on the work in Coppola, Maggiori, Neiman, and Schreger (2021) and were obtained from: www.globalcapitalallocation.com.

${ }^{18}$ Industry is defined as 10 unique NAICS industries as provided by the Global Capital Allocation Project.

${ }^{19}$ Specifically, we require that the non-missing number of investor-investee-industry-year observations for a given investee country in the GCAP data to be above the bottom $10^{\text {th }}$ percentile across the countries covered in the raw GCAP sample. This requirement predominantly drops economically very small countries where the data might be less reliable (Coppola et al. (2021)). In untabulated tests, including these smaller countries in our sample does not impact the inference of our results.
} 


\subsection{Variables Measurement and Descriptive Statistics}

\subsubsection{Key Dependent Variable: Foreign Portfolio Investment (FPI)}

Our measure of foreign demand for public equity, Log FPI Equity, is defined as the log of one plus the total portfolio investment in equity for each investee-industry-year following Coppola et al. (2021). ${ }^{20}$ Specifically, we use the "full nationality" global equity capital measure, which reassigns all investment positions to the investee country of the equity issuer's parent firm, regardless of whether the issuing entity is resident in a tax haven or not. This implicitly assumes that global investors are aware of the equity issuing entity's ultimate parent country. For example, a German investor who invests in Toyota Motors North America, a US-resident company, is assumed to have invested in Japan, the parent company's country. In robustness tests discussed further below, we show our results are qualitatively unaffected by using alternative definitions of global equity demand that are not strictly nationality-based, also developed by Coppola et al. (2021). Table 1 shows that our sample consists of 19 investor countries (Panel A) that invest in 460 investee-industries (i.e., 46 investee countries (Panel B) each with 10 NAICS industries (Panel C)) from 2005 to 2017. Table 1 Panel A Column (1) shows that the United States is by far the largest investor country in the global equity market (\$12.416 trillion) in 2017. Similarly, Table 1 Panel B Column (1) shows that the United States is also the largest investee country $\$ 10.686$ trillion), whereas Table 1 Panel C Column (1) reveals that the manufacturing industry is the largest recipient of global equity capital in 2017. Table 2 Panel A reveals that Log FPI Equity has a sample

\footnotetext{
${ }^{20}$ We define foreign or global equity capital allocation following Maggiori et al. (2020) and Coppola et al. (2021). This measurement may also capture a fraction of domestic investments in public securities, in particular when studying public equity demand of US securities (Coppola et al. (2021)). In untabulated tests, we verify that all inferences remain unchanged when we drop the FPI observations that likely capture domestic investments (i.e., when the investee and investor country are the same). In general, it is challenging to definitively determine the residency of the ultimate asset owner (e.g., the individual investor buying shares in a mutual fund) since this information is not reported in the data. However, Maggiori et al. (2020) argue that tax optimization and regulatory restrictions make it unlikely that investors buy mutual funds domiciled in other countries.
} 
mean of 2.18 across all investee countries with a standard deviation of 2.94. Figure 1 Panel A shows a heat map of Log FPI Equity across our sample investee countries.

\subsubsection{Key Independent Variable: Private Firm Disclosures}

\subsubsection{Measurement}

Our analysis requires a measure of private firm transparency at the investee-industry-year level. We use the BvD Orbis database to construct Transp. \% FS Items (private) defined as the number of non-missing financial statement line items disclosed by private firms in each investee-industryyear, divided by the total number of line items that these private firms can hypothetically disclose.

Orbis is the de-facto standard in providing private firm financial information and used by a wide range of clients around the world, including investment professionals for due diligence and market screening purposes (Business Wire (2020); Bureau van Dijk. (2021)). Thus, we assume the observability of financial statements in Orbis reflects the granularity and extent of disclosures consumed by global investors. We discuss the validity of this assumption in Appendix A.

We assume each private firm can disclose up to 39 standardized financial statement items as defined by $\mathrm{BvD}$ that categorize raw data from private firm financials into 39 distinct categories (Kalemli-Özcan et al. (2019)). That is, if there are 100 private firms in an investee-industry-year, the hypothetical full disclosure is 3,900. We provide a more detailed discussion on the construction of our measure in Appendix A. Mathematically, Transp. \% FS Items (private) is defined as follows:

$$
\text { Trans. \% FS Items (private) })_{j, n, t}=\frac{\sum_{k=1}^{N} \text { Disclosed FS Items }_{k, j, n, t}}{39 \mathrm{~N}}
$$

for private firm $k$, investee country $j$, industry $n$, year $t$. $\mathrm{N}$ denotes the total number of private firms with at least one financial statement item observable in a given investee-industry-year, whereas 39 represents the total number of (BvD standardized) financial statement items that each 
private firm can hypothetically disclose. Our measure therefore varies from $1 / 39$ to 1 , where higher values indicate that an investee-industry-year has private firms that are more transparent in the aggregate similar in spirit to Chen et al. (2015)'s measure based on publicly traded US firms. ${ }^{21}$

Table 1 Panel B shows that the average values of Transp. \% FS Items (private) for countries like the US, South Africa, and India are less than 10\%, whereas the averages for countries like Korea, France, and Brazil are above 70\%, indicating significant heterogeneity in the average private firm transparency across investee countries. Table 2 Panel A reveals that Transp. \% FS Items (private) has a sample mean of 0.57 across all investee countries with a standard deviation of 0.27. Figure 1 Panel B displays a heat map of Transp. \% FS Items (private) across our sample investee countries.

\subsubsection{Discussion}

Before we proceed, we note that variation in Transp. \% FS Items (private) could be driven by factors both exogenous and endogenous to the demand for public firm equity. For example, exogenous factors such as variation in disclosure enforcement in Europe or BvD's staggered coverage of private firms across the globe likely affect Transp. \% FS Items (private). On the other hand, endogenous factors like the voluntary decision by private firms to become more transparent (Breuer et al. (2020)) or their decision to comply with certain disclosure mandates can also impact our measure of private firm transparency (Bernard, (2016); Bernard et al. (2016); Breuer et al. (2020)). Ideally, we want our transparency measure to be driven by factors that are purely "domestic" in the sense of being exogenous to foreign investors' demand for public equity.

\footnotetext{
${ }^{21} \mathrm{We}$ note that our measure is an intensive margin measure of disclosure. That is, since we cannot observe the true number of private firms in an investee-industry due to data limitations, our scaler $\mathrm{N}$ is based on private firms that disclose at least 1 financial statement line item. Thus, Transp. \% FS Items (private) is best described as an average "disclosure quality" - as opposed to either disclosure quantity or the presence of disclosure (i.e., the extensive margin effect of disclosure). We thank an anonymous referee for raising this point.
} 
To assess this issue more explicitly, we explore the observable determinants of investee countries' private firm transparency in Table 1 Panel D. We find evidence that suggests the variation in our transparency measure is primarily driven by factors that are domestic, and less so by foreign country factors. This is broadly consistent with the view that domestic stakeholders are the primary driver of private firm disclosures and alleviates concerns that the empirical link between private firm transparency and future foreign equity demand is spurious (Breuer, Hombach and Mueller (2020)).

Specifically, Table 1 Panel D Columns (1) and (2) show that a host of observable domestic factors have statistically significant relations to one-year-ahead Transp. \% FS Items (private) when either fixed effects are omitted (Column (1)) or only investee-industry fixed effects are included (Column (2)). In Column (3), we include both investee-industry and year fixed effects and find that domestic factors such as Log Country GDP, Log. No. Private Firms, Revenue Growth, and Log. Median Size (Total Assets) have significant statistical relations with one-year-ahead Transp. \% FS Items (private). On the other hand, in Column (3) we find that foreign factors such as Log. FPI Equity and FDI (\% of GDP) do not have a statistically significant link to future one-year-ahead Transp. \% FS Items (private).

While these findings raise the bar for omitted variables to jointly determine both domestic private firm transparency and future foreign public firm equity, we take several steps to further tighten our identification strategy to get as close as possible to estimating a causal relationship. Specifically, in all our tests we include a dense fixed effect structure (discussed further below) as well as time-varying controls to alleviate concerns related to certain confounding factors driving our results. Moreover, we exploit the staggered openings of $\mathrm{BvD}$ offices and electronic business 
registration among European countries to generate exogenous variation in private firm transparency in later tests.

Notwithstanding the issues on causality, an important appeal to our measure is that it is easily implementable and broadly applicable to many settings. These features are in line with one of our goals of this study, which is to provide a private firm transparency measure that future researchers can utilize in various global settings. More broadly, in contrast to prior work that exploits regulatory shocks in Europe (e.g., Bernard (2016); Breuer et al. (2020); Baik et al. (2020); Glaeser and Omartian (2021)), we are interested in the effects of variation in aggregate transparency attributable to factors beyond regulatory reporting mandates in the global equity market.

\subsection{Research Design}

The empirical model we use is as follows:

Log. FPI Equity ${ }_{i, j, n, t}$

$$
\begin{aligned}
& \left.=\beta_{1} \text { Transp. } \% \text { FS Items (private }\right)_{j, n, t-2}+\beta_{k} \overline{X_{j, n, t-2}}+\delta_{i, j, n}+\gamma_{t} \\
& +\epsilon_{i, j, n, t}
\end{aligned}
$$

The unit of observation is at the investor country $i$, investee country $j$, investee industry $n$, and year $t$ level. We cluster standard errors at the investee-industry-year level. Our coefficient of interest, $\beta_{1}$, captures the percentage increase in foreign investor demand for public equity associated with a $1 \%$ increase in our private firm transparency measure. Specifically, Log. FPI Equity is the annual foreign investor demand for public equity as discussed in Section 3.2.1. Transp. \% FS Items (private) is our transparency measure of interest as discussed in Section 3.2.2. We compute Transp. \% FS Items (private) in year $t$-2 (where $t$ is the year Log. FPI Equity is measured) to account for the typical one-year lag between the fiscal year end and the publication date of financial statements by private firms, as well as the additional time commercial database providers like $\mathrm{BvD}$ take to collect, standardize, and disseminate data to professional investors 
around the world (e.g., Moody's (2018); Kalemli-Özcan et al. (2019); Breuer, Hombach, and Muller (2020)). ${ }^{22} \overline{X_{\jmath, n, t-2}}$ is a vector of controls, which include public firm transparency (Transp. \% FS Items (public)), log number of public firms (Log. No. Public Firms), log number of private firms (Log. No. Private Firms), log median firm size measured by total assets (Log. Median Size (Total Assets)), return on assets (ROA), revenue growth (Revenue Growth), log investee country GDP (Log. Country GDP), log population (Log. Population), and foreign direct investments as a $\%$ of GDP (FDI \% of GDP. The definitions of all variables are in Appendix B.

Our selection of control variables is motivated by the discussion of potential correlated factors in section 3.2.2.2. In particular, the inclusion of performance characteristics (ROA and Revenue Growth) mitigates the concern that greater investment opportunities and higher returns on investment induce firms to disclose more while simultaneously determining capital allocation decisions. Further, we control for time-varying changes in levels of publicly available reports due to reporting regulation, capital market size, and macroeconomic factors by including Transp. \% FS Items (public), Log. No. Public Firms, Log. No. Private Firms, as well as investee country level economic characteristics such as Log. Country GDP, Log. Population, and FDI (\% of GDP).

The inclusion of investor-investee-industry $\left(\delta_{i, j, n}\right)$ and year $\left(\gamma_{t}\right)$ fixed effects in equation (2) alleviates much of the concern that omitted investee or industry characteristics are driving foreign demand for public equity. These fixed effects account for much of the confounding factors that vary across investee countries (e.g., capital market development) and across industries (e.g., investment opportunities), as well as those that trend over time within countries and industries. Thus, our empirical design estimates $\beta_{1}$ by exploiting time-series variation in treatment intensities

\footnotetext{
${ }^{22}$ Our results are robust to measuring Transp. \% FS Items (private) in years t-1 or t-3.
} 
(i.e., the degree of private firm transparency) within the same investor-investee-industry level. ${ }^{23}$ Nonetheless, to further corroborate the inferences of our main findings, we perform a series of additional tests that help rule out other plausible interpretations of our results. We discuss these results in more detail in Section 4.

\section{RESULTS}

\subsection{The Impact of Private Firm Disclosures on Public Equity Demand}

We predict a negative link $\left(\beta_{1}<0\right.$ in Equation (2)) between private firm disclosures and foreign demand for public equity if private firm disclosures are primarily idiosyncratic and induce a reallocation of capital from public firms to more transparent private firms (i.e., disclosures generate negative pecuniary externalities). On the other hand, we predict a positive link $\left(\beta_{1}>\right.$ 0 in Equation (2)) between private firm disclosures and foreign demand for public equity if private firm disclosures generate positive information externalities that benefit public firm valuations.

Table 2 Panel B provides univariate evidence that the relationship between Transp. \% FS Items (private) and Log. FPI Equity is significantly negative. Specifically, we document a $-8.2 \%$ Pearson correlation (row (2) column (1)), consistent with private firm disclosures generating negative pecuniary externalities on public firm equity demand.

In Figure 2 and Table 3 we extend the univariate findings of Table 2 Panel B by regressing Log. FPI Equity on Transp. \% FS Items (private) with a set of relevant controls and fixed effects as defined in Equation (2). Specifically, Figure 2 provides a visual impression of the relationship

\footnotetext{
${ }^{23}$ To provide a visual perspective of the variation we exploit in our regressions, in Figure A1 of Appendix C, we plot the residual variation of our transparency measure (i.e., the residual obtained from regressing our transparency measure on a set of controls and the investor-investee-industry fixed effect) for the USA, the UK, and Germany as illustrative examples. We provide a more detailed discussion in the notes of Figure A1 of Appendix C to explain the plausible underlying forces that drive the time-series variation for these countries.
} 
between Log. FPI Equity and Transp. \% FS Items (private) through binned scatter plots, where the bins are based on the percentile values of Transp. \% FS Items (private). To control for confounding effects when plotting this relationship, we estimate the residuals from a regression of Log. FPI Equity on investor-investee-industry fixed effects, year fixed effects, and a set of control variables. Both the scattered mean values within bins (blue dots) and the fitted linear regression line (red line) indicate a significantly negative relationship (slope coefficient of $-0.39, \mathrm{p}$ value $<0.01$ ) between private firm transparency and future foreign demand for public equity, corroborating the univariate evidence documented above.

Consistent with the visual evidence in Figure 2, Table 3 Panel A demonstrates a significant negative link between Transp. \% FS Items (private) and Log. FPI Equity in a regression framework. Column (1) contains results with investor-investee-industry fixed effects but no controls, Column (2) with investor-investee-industry fixed effects and controls, and Column (3) with investorinvestee-industry fixed effects, year fixed effects, and controls. The coefficient stability across all three specifications offers reassurance that our results are not sensitive to model specifications and certain omitted factors $($ coef. $=-0.374, \mathrm{t}$-stat $=-6.65$ in Column $(1)$; coef. $=-0.433$, t-stat $=-4.62$ in Column (2); coef. $=-0.387$, t-stat $=-4.22$ in Column (3)). In economic terms, a one standard deviation increase in Transp. \% FS Items (private) (i.e., a 27 percentage-point increase) is associated with a $11 \%$ (Column (2)) to $12 \%$ (Column (3)) or $\$ 174$ million to $\$ 190$ million decrease in average total future equity demand by foreign investors per investee-industry-year, suggesting that the effect is material. ${ }^{24}$

\footnotetext{
${ }^{24}$ Specifically, the percentage effects are based on multiplying the coefficient estimates to the one standard deviation effect of Transp. \% FS Items (private), which is 27 percentage points. Moreover, the dollar value estimates are based on the average total foreign portfolio per investee-industry-year in our sample, which is $\$ 1.58$ billion.
} 
In Table 3 Panel B, to better understand what information foreign investors are consuming, we dissect our private firm disclosure measure into three subcomponents - balance sheet items (Transp. \% BS Items (private); Columns (1) and (2)), income statement items (Transp. \% PL Items (private); Columns (3) and (4)), and footnote items (Transp. Notes Items (private); Columns (5) and (6)). Using the model specifications in Table 3 Panel A, we find that all three subcomponents have strong negative links to future public equity demand. Specifically, Columns (1), (3), and (5) reveal that a one standard deviation increase in balance sheet items, income statement items, and footnote items is associated with a $11 \%, 9 \%$, and $23 \%$ decrease in public equity demand, respectively $($ coef. $=-0.607, \mathrm{t}-$ stat $=-4.42$ in Column $(1)$; coef. $=-1.138, \mathrm{t}$-stat $=-3.21$ in Column (3); coef. $=-4.583, \mathrm{t}-\mathrm{stat}=-4.86$ in Column (5)). ${ }^{25}$ The statistically significant effects across all specifications suggest that global investors find various elements of the financial statements useful when reallocating capital. ${ }^{26}$ These results broadly speak to the call by Ferracuti and Stubben (2019) for more analyses that identify the specific types of information financial statement users consume when making economic decisions such as capital allocation.

\subsection{Corroborating the Reallocation Interpretation of the Decline in Public Equity Demand}

A reallocation of capital from public equity to investment in private firms is implicitly assumed in the argument that private firm disclosures reduce demand for public firm equity. We address this implied relationship in three steps by exploiting investor-investee country pair characteristics.

\footnotetext{
25 The one standard deviation increase for balance sheet items, income statement items, and footnote items are 0.18 , 0.08 , and 0.05 , respectively as shown in Table 2 Panel A.

${ }^{26}$ In untabulated analyses, we further decompose our private firm transparency measure Transp. \% PL Items (private) into its 39 standardized line items and find that a significant majority - 27 out of 39 - have a negative relation with future equity demand. While these findings confirm the notion that investors find various parts of the financial statements relevant the results also show exceptions such as Revenue and COGS that have a positive effect on public equity demand. Although it is beyond the scope of this paper, we believe more closely examining the heterogeneous effects across individual financial statement line items to be an interesting extension to our work.
} 


\subsubsection{Capital Constraints Inducing Reallocation of Capital}

We expect and find the negative link between Transp. \% FS Items (private) and Log. FPI Equity is more pronounced when investors are constrained in their ability to invest new capital in an investee country, consistent with reallocation of capital driving our results. We leverage the idea that constrained global investors are more likely to reallocate their existing capital (i.e., public equity) - rather than invest new capital - to make new investments to transparent private firms (Stiglitz (1981); Siriwardane (2019)).

Empirically, we exploit the bilateral nature of our data and compute two proxies for the constraints faced by investors in investing new capital in an investee country. Our first proxy measures the strictness in controlling foreign capital flows between investor-investee pairs. Specifically, we define Capital Control to equal 1 if "investor's outflow control*investee's inflow control" is in the top decile, and 0 otherwise. Both inflow control and outflow control are scorebased measures based on 10 categories that represent a country's strictness in controlling foreign capital where higher values indicate greater strictness in the flow of foreign capital based on Fernández et al. (2016) and Makarov and Schoar (2020). ${ }^{27}$ Our second proxy measures the relative currency appreciation of the investee country. We expect investors to be more constrained in investing new capital when the investee country's currency is relatively more expensive to the investor's (Blonigen (1997); Desai et al. (2008); Berg et al. (2021)). Specifically, using the BvD EIU Country data, we define Currency Appreciation to equal 1 if the percentage increase of the investee country's annual real effective exchange rate is in the top decile, and 0 otherwise.

\footnotetext{
${ }^{27}$ More specifically, the 10 categories include the strictness in controlling foreign equity, financial credits, direct investments, among others. To compute a country's strictness, we follow Fernández et al. (2016) and average across the scores (that ranges from 0 to 1 ) assigned to each category. We thank Fernández et al. (2016) for generously providing the data: http://www.columbia.edu/ mu2166/fkrsu/.
} 
Table 4 Column (1) documents a significant negative link between Log. FPI Equity and the interaction term Transp. \% FS Items (private)*Capital Control $($ coef. $=-0.258, \mathrm{t}$-stat $=-3.42)$. Column (2) shows a significant negative link between Log. FPI Equity and the interaction term Transp. \% FS Items (private) $*$ Currency Appreciation $($ coef. $=-0.324$, t-stat $=-3.33$ ). To allow for a differential mapping of controls as well as year trends into the demand for public equity for constrained versus unconstrained investor-investee-years, we also interact our control variables and year fixed effects with Capital Control. Note that the Capital Control main effect is subsumed because of the inclusion of Year FE*Capital Control. In economic terms, being in the top decile investor-investee pair in our two proxies for investor constraints result in a $25.8 \%$ (Column (1)) to 32.4\% (Column (2)) additional reduction in public equity demand relative to baseline averages.

\subsubsection{Language and Physical Distances between Investor and Investee Countries}

We expect and find the negative link between Transp. \% FS Items (private) and Log. FPI Equity is more pronounced when the investor and investee countries are more "distant" to each other either in terms of language or geographically. This is consistent with private firm disclosures playing a greater role when information frictions are more severe because of greater distances between countries (Lang, Maffett, Omartian, and Silvers (2020)). Specifically, we summarize the various measures of language distance provided by the CEPII database by computing the principal component of these measures. ${ }^{28} \mathrm{We}$ then define Language Distance to equal 1 if the first principal component of an investee country is in the top decile and 0, otherwise. Similarly, we aggregate the various measures of physical distance available through CEPII by computing the principal

\footnotetext{
${ }^{28}$ The measures provided by CEPII include non-common official language, non-common spoken language, and general language differences using the Tree and the ASJP methods. See Mayer and Zignago (2011) and Melitz and Toubal (2012) for more details. Moreover, see Baker and Wurgler (2006) and Johnson, Kim, and So (2020) for recent examples of using principal component analysis to compute a composite proxy such as Language Distance.
} 
component and define Physical Distance to equal 1 if the first principal component is in the top decile and 0, otherwise. Further details are provided in Appendix B.

Table 4 Column (3) demonstrates a significant negative link between Log. FPI Equity and the interaction term Transp. \% FS Items (private $) *$ Language Distance $($ coef. $=-0.363$, t-stat $=-2.59)$. Column (4) shows a significant negative link between Log. FPI Equity and the interaction term Transp. \% FS Items (private $) *$ Physical Distance $($ coef. $=-0.223, \mathrm{t}-\mathrm{stat}=-2.10)$. In economic terms, being in the top decile in terms of investor-investee pair language distance results in a $36.3 \%$ (Column (3)), being in the top decile in terms of physical distance results $22.3 \%$ (Column (4)) additional reduction in public equity demand relative to baseline averages.

\subsubsection{Capital Being Reallocated to Private Firms}

We expect and find that investee countries that experience the most significant reduction in public equity are indeed the ones that experience the greatest inflow of foreign capital into private firms, consistent with reallocation of capital driving our results. We show this in two ways.

First, we relate the predicted demand for public equity based on the fitted values using Equation (2) ("Predicted Log. FPI") with our proxy for global investors' demand for private firm equity Log. Number of $M \& A$ Deals (private). Using a binned scatter plot, Figure 3 Panel A reveals a statistically significant negative relationship between Predicted Log. FPI and Log. Number of $M \& A$ Deals (private). The slope coefficient is estimated to be -0.20 with a p-value less than 0.01 . Recalling that higher private firm financial transparency predicts lower FPI, this finding supports the conclusion that a decrease in foreign investors' demand in public firm equity (as induced by 
increases in private firm transparency) is associated with an increase in demand for private firm equity (via increased M\&A demand) in the same investee, industry, and year. ${ }^{29}$

Second, Figure 3 Panel B shows the direct relationship between global investors' demand for private firm equity and private firm financial transparency (Transp. \% FS Items (private)). Consistent with capital being reallocated to private firms, we find a significant positive link between private firm financial transparency and domestic M\&A activity of foreign investors ( $L o g$. Number of $M \& A$ Deals (private)). The slope coefficient of the linear regression line is 0.04 and statistically significant $(\mathrm{p}$-value $<0.01)$.

Table 5 Columns (1), (2), and (3) confirm the visual evidence in Figure 3 Panel B and suggest that higher private firm financial transparency (Transp. \% FS Items (private)) is associated with a greater allocation of capital into private firm equity via various proxies for private firm $M \& A$ activity as defined in Appendix B. In economic terms, Column (1) suggests that a one standard deviation increase in private firm transparency increases the likelihood of a private firm being targeted by a foreign investor by $12 \% .{ }^{30}$ Similarly, in Columns (2) and (3) we document that a one standard deviation increase in Transp. \% FS Items (private) is linked to 9.1\% and 7.5\% more foreign capital being used to acquire private firms relative to the total deal value and the latest revenue figures of the private target firms, respectively. ${ }^{31}$

\footnotetext{
${ }^{29}$ Details on the construction of the sample on capital investments in private firms are in Table A2 of Appendix C. While we obtain M\&A deal information from BvD through their Zephyr database and measure private firm disclosures using BvD's Orbis database, it is very unlikely that our tests pick up a mechanical positive relationship between private firm disclosures (measuring using BvD's Orbis database) and investments in private firms (observed in the Zephyr database). Zephyr collects its deal information from timely sources such as acquirers firms webpages or press releases and newspaper articles. Consistently, in untabulated tests we observe that trends M\&A activity with private firms expectedly follow economic developments and are not strongly correlated with private firm coverage in Orbis.

${ }^{30}$ Specifically, the baseline probability of a private firm being targeted by a foreign investor is $9.6 \%$. The coefficient estimate in Column (1) suggests a $1.12 \%(=27 \%$ multiplied by 0.044$)$ increase per one standard deviation increase in Transp. \% FS Items (private). A $1.12 \%$ increase represents a $12 \%$ increase relative to the $9.6 \%$ baseline probability.

${ }^{31}$ These estimates are attained by multiplying 0.27 (a one standard deviation increase in Transp. \% FS Items (private)) to the regression coefficients.
} 
Moreover, we document a negative relation between private firm transparency and M\&A activity that targets public firms in Columns (4) through (6). The negative relation mitigates concerns related to investors reallocating capital between public firms (in which case we would have expected a positive relation), further corroborating the inference that the reduction in demand for public equity is likely due to investors reallocating capital to private firms.

To further corroborate the reallocation mechanism, Table 5 Panel B displays the result from running analogous regressions using venture capital transactions - another important dimension of investments in younger private firms - as opposed to M\&As of typically more mature private firms. Consistent with Baik et al. (2020) who relate VC transactions to higher financial statement availability due to regulation, the regression result in Column (1) suggests that a one standard deviation increase in private firm transparency increases the likelihood of a private firm receiving foreign VC by $27 \% .{ }^{32}$ Similarly, Columns (2) and (3) suggest that a one standard deviation increase in private firm transparency increases the inflow of foreign VC capital by $4.9 \%$ and $2.8 \%$ relative to the total deal value and the latest revenue of the target private firms, respectively. ${ }^{33}$

\subsection{Which Private Firms Benefit from Greater Transparency?}

The findings in Section 4.2 demonstrate that private firm disclosures induce a reallocation of capital from public equity to investment in private firms. To further shed light on which private firms - the disclosing private firm versus its private firm peers - specifically benefit from the reallocation of capital, we conduct a firm-level analysis. To do so, we create a firm-level measure of our private firm transparency, Firm Transp. \% FS Items (private), analogously defined as the

\footnotetext{
${ }^{32}$ Specifically, the baseline probability of a VC deal occurring is $1.5 \%$. The coefficient estimate in Column (1) suggests a $0.41 \%$ increase per one standard deviation increase in Transp. \% FS Items (private). A $0.41 \%$ increase represents a $27 \%$ increase relative to the $1.5 \%$ baseline probability.

${ }^{33}$ The reader should interpret the economic magnitudes here with caution. Since firms receiving VC are very young, we only observe their financial statement information on assets and revenues in about $21 \%$ and $16 \%$ of the cases. And book values are often noisy predictors of the market value of capital for young growth firms.
} 
number of non-missing financial statement line items disclosed by the individual private target firm in a given year, divided by the 39 line items that the firm can hypothetically disclose. We then construct our dependent variable of interest, Private Firm M\&A Acquisition (0/1), to be an indicator taking on the value of 1 in the year a private firm is acquired by a foreign investor. Similar to our investee-industry analysis, we measure Firm Transp. \% FS Items (private) at year $t$-2, where $t$ is the year our dependent variable is measured. Our firm-year sample is comprised of private firms that eventually get acquired by foreign investors during our sample period $(23,794$ unique deal-years as described in Table A2), where target firm-year observations are removed after the M\&A deal. This results in a sample of 89,947 target firm-year observations.

Table 6 Columns (1) and (2) show a statistically significant positive relation between Firm Transp. \% FS Items (private) and Private Firm M\&A Acquisition (0/1) $($ coef. $=0.079$, t-stat $=7.99$ in Column (1); coef. $=0.080$, t-stat $=4.93$ in Column (2)). Specifically, Column (1) suggests a one standard deviation increase in Firm Transp. \% FS Items (private) (a 17 percentage-point increase) is associated with a $7 \%$ incrementally higher likelihood of being targeted by a foreign investor. ${ }^{34}$ This is consistent with the reallocation of public equity benefiting the disclosing private firm. In Columns (3) and (4), we include our investee-industry wide measure of transparency, Transp. \% FS Items (private), to assess the externality effects of private firm disclosures on other private firm peers. We find a statistically significant positive relation between our industry wide measure, Transp. \% FS Items (private), and Private Firm M\&A Acquisition (0/1) $($ coef. $=0.044$, t-stat $=$ 1.76 in Column (1); coef. $=0.063, \mathrm{t}$-stat $=2.10$ in Column (2)). In stark contrast to the negative pecuniary externalities of private firm disclosures on public firms, this finding suggests that private

\footnotetext{
${ }^{34}$ The baseline average probability of being a target in our sample is 0.18 . Thus, we derive $5 \%$ from multiplying $17 \%$ by 0.079 and dividing this number by 0.18 .
} 
firm disclosures generate positive information externalities to other private firms. ${ }^{35}$ Taken together, we find evidence consistent with capital reallocation of public equity benefiting both the disclosing private firm and its private firm peers.

\subsection{Causal Inference: Distribution Lag Model and Difference-in Differences Tests}

If the increase in private firm transparency (Transp. \% FS Items (private)) is related to unobserved factors that determine the demand for public equity by foreign investors ( $\log$. FPI Equity), the estimated relation between Transp. \% FS Items (private) and Log. FPI Equity may be biased. We address this issue in two ways. First, we use a distributed lag model, a technique adopted from the economics literature on the dynamics of corporate investment (e.g., Suarez Serrato and Zidar (2016)), to assess the cumulative effects of private firm transparency on public equity demand over different time horizons. Second, we use two settings that provide for countrylevel shocks to private firm transparency - staggered openings of BvD global offices and the staggered introduction of electronic business registers in Europe - to conduct difference-indifferences analyses.

\subsubsection{Distributed Lag Model}

Figure 4 plots the results of estimating a distributed lag model. To do so, we first compute the annual point estimates by regressing Log. FPI Equity on the contemporaneous as well as several lead and lag values of Transp. \% FS Items (private) with controls, investor-investee-industry and

\footnotetext{
${ }^{35}$ These results are consistent with the idiosyncratic effect of private firm disclosures playing a more significant role against public firms that operate in higher quality information environments. That is, the incremental informational benefits of private firm disclosures are likely smaller than the idiosyncratic negative pecuniary externalities. On the other hand, private firm peers that tend to be in more opaque environments are more likely to benefit from private firm disclosures. Table 2 Panel A provides empirical support for this argument. While the mean value of private firm transparency (Transp. \% FS Items (private)) is 0.57 with a standard deviation of 0.27 , public firm transparency (Transp. \% FS Items (public)) has a much higher mean of 0.84 with significantly lower standard deviation of 0.07 , suggesting that public firms are significantly more transparent, and also consistently so, around the world.
} 
year fixed effects. ${ }^{36} \mathrm{We}$ then plot the cumulative sum of the annual point estimates. The years on the x-axis represent the year in which Log. FPI Equity is observed relative to the year in which Transp. \% FS Items (private) is observed. For example, the year $\mathrm{t}=-3$ means that the coefficient estimate is based on relating the three-year lead of Transp. \% FS Items (private) to contemporaneous Log. FPI Equity (i.e., Log. FPI Equity is three years behind relative to Transp. \% FS Items (private)). Each subsequent year (i.e., $\mathrm{t}=-2$ through +5 ) cumulates the annual coefficient estimates. For example, the coefficient plotted in year $t=-1$ (i.e., 0.03) is the sum of the coefficient estimates from $t=-3, t=-2$, and $t=-1$ (i.e., annual regression coefficients based on leads three, two, and one year of Transp. \% FS Items (private) relative to contemporaneous Log. FPI Equity).

We find a statistically insignificant cumulative effect leading up to the year in which Transp. \% FS Items (private) is contemporaneously measured at $\mathrm{t}=0$ (i.e., $p$-value $=0.80$ ). This suggests that there is no evidence of changing trends in the demand for public equity leading up to the measurement of private firm disclosures, which alleviates concerns related to reverse causality of log. FPI being a leading factor of private firm transparency. On the other hand, we find a statistically significant effect after the year Transp. \% FS Items (private) is measured ( $p$-value < 0.01). The effect becomes only significant 2 years after the measurement of Transp. \% FS Items (private) and gradually grows in significance over time. These dynamic patterns suggest private firm disclosures disseminate to investors with some lag, consistent with the views of our paper.

\subsubsection{Difference-in-Differences: Settings and Research Design}

We employ two complementary difference-in-differences (DiD) settings to further help establish a causal link between private firm transparency and foreign investor demand for public

\footnotetext{
${ }^{36}$ Specifically, we include up to five lagged and three lead values of private firm transparency. Relative to our original sample period of 2005 to 2017 for which the FPI data is available, we are still able to use FPI data from 2005 to 2016 as we observe private firm financial data from 2000 to 2019.
} 
equity. The first setting we use is the staggered openings of $\mathrm{BvD}$ offices across investee countries, which to our knowledge is a novel approach to tackling endogeneity issues related to private firm disclosures. We hand-collected information on $\mathrm{BvD}$ global office openings from the online professional networking site LinkedIn. Table A3 of Appendix C provides details on the data collection procedure and displays the location and year of the office openings.

The motivation for using BvD office openings is twofold. First, these openings represent a significant increase in the resources spent in collecting, standardizing, and transmitting financial reports of private firms to global investors. Second, while opening decisions may be driven by investee country factors like GDP or the legal environment, we contend that the exact timing of each office opening in the investee country is more likely to be incidental and driven by factors not directly linked to the variations in the foreign demand for public equity conditional on our fixed effects and controls. We find empirical support for this identifying assumption in Table A4 of Appendix C. In particular, when investee and year fixed effects are included, we document, foreign equity demand (Log. FPI Equity) and foreign direct investment (FDI (\% of GDP) to be statistically unreliable predictors of $\mathrm{BvD}$ office openings in the following year, assuaging concerns related to the office openings being correlated with foreign demand for public equity. On the other hand, we find domestic factors - in particular, GDP - to be strongly associated with office openings. This finding is consistent with $\mathrm{BvD}$ expanding to foreign markets that likely have a growing customer base. While this suggests the office openings are not strictly random, it is less clear how an increase in GDP would explain a negative relation between private firm disclosure and future public equity demand as we document in this paper. We acknowledge, however, that it is impossible to completely rule out that certain omitted factors might violate the exogeneity assumption of our staggered difference-in-differences design. 
The second setting we use is the implementation of electronic business registers in Europe. The implementation of these business registers represents European countries' effort to reduce the costs of private firms to comply with accounting regulation, facilitate the dissemination of private firm information (similar to that of the EDGAR implementation that took place the US), and impose stricter enforcement of private firm disclosure mandates. ${ }^{37}$ Breuer and Breuer (2020) argue that the timing differences in register implementations across European countries are exogenous, lending support to the validity of identifying assumptions in a DiD design. Table A5 of Appendix $\mathrm{C}$ provides details on the staggered implementation across the affected European countries.

To implement the DiD design, we estimate the following related regressions for the settings:

$$
\text { Log. FPI Equity }{ }_{i, j, n, t}=\mu_{1} \text { PostBvDOffice }_{j, t}+\beta_{k} \overline{X_{J, n, t}}+\delta_{i, j, n}+\gamma_{t}+\epsilon_{i, j, n, t}
$$

Log. FPI Equity $y_{i, j, n, t}=\mu_{1}$ PostBusinessRegister $r_{j, t}+\beta_{k} \overline{X_{j, n, t}}+\delta_{i, j, n}+\gamma_{t}+\epsilon_{i, j, n, t}$

where the indicator variable PostBvDOffice ${ }_{j, t}$ (PostBusinessRegister $_{j, t}$ ) equals to one in the years following a $\mathrm{BvD}$ office opening (the start of the operation of an electronic business register) in given investee country $j$ and year $t$. The unit of observation is at the investor country $i$, investee country $j$, investee industry $n$, and year $t$ level. Our coefficient of interest, $\mu_{1}$, captures the difference-in-differences estimate of the foreign investor demand for public equity as a result of a BvD office opening in an investee country (Equation (3)) and the electronic business register being implemented in a European country (Equation (4)). $\overline{X_{J, n, t-2}}$ is a vector of controls as described in Equation (1) of Section 3.3. Investor-investee-industry fixed effects $\left(\delta_{i, j, n}\right)$ and year fixed effects $\left(\gamma_{t}\right)$ are included to absorb unobserved cross-country heterogeneity and time trends. We cluster standard errors at the investee-industry level.

\footnotetext{
${ }^{37}$ See Breuer and Breuer (2020) for additional institutional details on the implementation of the electronic business registers in Europe.
} 


\subsubsection{Difference-in-Differences Results}

Table 7 Panel A demonstrates a significant negative relation between PostBvDOffice $e_{j, t}$ and Transp. $\%$ FS Items $(\text { private })_{j, t}$ (i.e., $\mu_{1}<0$ ), with an estimated coefficient of $-0.323(\mathrm{t}-\mathrm{stat}=$ -5.96) in Column (1) with investor-investee-industry and year fixed effects, whereas a coefficient of -0.320 (t-stat $=-6.12)$ in Column (2) with investor-investee-industry and industry-year fixed effects. Economically, these difference-in-differences estimates imply an 32\% or 512 million reduction in public equity demand after a BvD office opens in an investee country compared to investee countries that did not open a BvD office yet. Both of these estimates are based on the sample of investee countries that eventually open a BvD office. In Column (3) and (4) we use the full sample of investee countries including those that never open a $\mathrm{BvD}$ office and find qualitatively similar results that imply a $22.4 \%$ or 355 million decrease in public equity demand.

Table 7 Panel B shows a significant negative relation between PostBusinessRegister $r_{j, t}$ and Transp. \% FS Items $(\text { private })_{j, t}$ with an estimated coefficient of $-0.152(\mathrm{t}$-stat $=-3.32)$ in Column (1) with investor-investee-industry and year fixed effects, whereas a coefficient of -0.156 $(\mathrm{t}-\mathrm{stat}=-3.58)$ in Column (2) with investor-investee-industry and industry-year fixed effects. Economically, these difference-in-differences estimates imply a $15.2 \%$ or 241 million reduction in public equity demand after an investee country implements the electronic business register compared to investee countries that did not implement the register yet. Both of these estimates are based on the sample of investee countries that eventually open a BvD office. In Column (3) and (4) we use the full sample of investee countries including those that never open a BvD office and find qualitatively similar results that imply a $13.7 \%$ or 217 million decrease in equity demand.

In Figure 5 Panel $\mathrm{A}$ we plot the estimations in event-time to validate the parallel trends assumption and to test for effect dynamics (Barrios (2021)). Specifically, the graph plots 
difference-in-differences point estimates for the period from two years prior to the BvD opening $(t=-2)$ up to three years after the opening $(t=+3)$ with $90 \%$ confidence intervals. Similarly, in Figure 5 Panel B we plot the estimations in event-time two years prior to the implementation of electronic business registers $(t=-2)$ up to three years after the implementation $(t=+3)$ with $90 \%$ confidence intervals. Consistent with both the staggered office openings and business registers being unrelated to trends in private firm transparency, we document insignificant effects around zero before $\mathrm{t}=0$. We observe an immediate negative and statistically significant effect of about 0.3 one year after the BvD openings (0.2 one year after the business register implementations), consistent with our regression estimates in Table 7 . Taken together, we conclude that the negative relation between Transp. \% FS Items (private) and Log. FPI Equity is unlikely to be spurious.

\subsection{Robustness}

We conduct a number of tests to validate the robustness of our results. Table 8 Panel A Column (1) shows that we continue to document a strong negative relation between private firm transparency and foreign public equity demand in a more restrictive fixed effect structures (i.e., with the inclusion of investor-industry-year fixed effects). Intuitively, this fixed effect exploits cross-sectional variation across different investee countries that share the same investor and industry in a given year. Moreover, Columns (2) through (5) show that our results are not sensitive to alternative definitions of private firm transparency. Specifically, Column (2) defines private firm transparency as the total number - not percentage - of line item disclosures in a given investee-industry-year (i.e., the numerator of Equation (1) in Section 3.2.2.1). Column (3) scales

Column (2)'s measure by Industry GDP. Column (4) weights Transp. \% FS Items (Private) by 
firms' revenues. Column (5) uses quintile values of our private firm transparency measure as opposed to raw percentage values..$^{38}$

Table 8 Panel B tests the robustness of our findings using different definitions and sampling requirements of our dependent variable of interest - Log. FPI Equity. Specifically, Column (1) shows our results are robust to excluding observations with Log. FPI Equity $=\$ 0$ in the global capital allocation data, which helps us estimate an intensive margin effect between private firm disclosure and foreign demand for public equity. ${ }^{39}$ Columns (2) and (3) demonstrate our results are robust to using an alternative definitions outlined by Maggiori et al. (2020). Specifically, Log. FPI Equity (tax haven) is the same as Log. FPI Equity but only foreign portfolio investments made to entities in tax havens are reassigned to the incorporation country of the entities' parent (whereas Log. FPI Equity used throughout the paper reassigns to the incorporation country of the parent for investments made to both tax havens and non-tax havens). Log. FPI Equity (residency) is the same as Log. FPI Equity but defines investee countries based on "residency" (i.e., the incorporation country) of the immediate issuer of equity, not the incorporation country of the parent.

Finally, to assess whether our findings are driven by an undue influence of a single country (e.g., due to lower data quality or a disproportionate influence of certain countries) we conduct a jackknife analysis excluding each investor and investee country one at a time and re-running our main tests. Figure 6 shows that our findings in Table 3 our robust to excluding investors (Panel A) and investees (Panel B) one at a time. Re-running our main specification based on a restricted,

\footnotetext{
${ }^{38}$ In untabulated tests, we find our results are robust to and value-weighted observations using means, sums, and percentiles (based on means and sums) of FPI by investor-investee pair similar in spirit to Lang et al. (2020).

${ }^{39}$ As a technical point, observations with " $\$ 0$ " allocation of public equity imply that an investee-industry-year received an insignificant amount of investment (i.e., less than $1 \%$ of total equity investment in an investee-year) by a certain investor as outlined by Coppola et al. (2021).
} 
fully balanced sample yields qualitatively and quantitatively very similar results (untabulated). We conclude that our results are not driven by data coverage or influential observations.

\section{CONCLUSION}

We study the effects of private firm disclosure on the demand for public firm equity. Using data on the global movement of public equity, we find that a one standard deviation increase in private firm disclosure transparency - proxied by the number of disclosed private firms' financial statement line items - reduces global investors' demand for public equity by $11 \%$ to $12 \%$ or by $\$ 174$ million to $\$ 190$ million in dollar terms at the investee-industry level. Our results are consistent with private firm disclosures generating negative pecuniary externalities - global investors reallocate their capital away from public firms to more transparent private firms - and less consistent with these disclosures creating positive information externalities that would benefit public firms. Consistent with this interpretation, we find that the reduction in demand for public equity is offset by a comparable increase in capital allocation to more transparent private firms.

Our paper contributes to the emerging literature on private firm transparency by highlighting an important but underexplored externality effect of private firm disclosures on public firm equity demand. By doing so, we extend the disclosure externality literature that has primarily focused on the externality effects of public firm disclosures, but less so on the externality effects of private firm disclosures, to date. Further, we contribute to the literature that examines the allocation of global capital by showing private firm disclosure is an important determinant for global capital movements. Last, our private firm transparency proxy is broadly applicable and can be used in various international settings by future researchers.

Our findings, however, should be interpreted with a few caveats in mind. First, while our findings are suggestive, they are not conclusive evidence of investors reallocating public equity 
capital to private firms. While reallocation is an important part of our proposed narrative, the capital allocation decisions at the investor or transaction level are unobservable to us. Second, while our fixed effect structures and difference-in-differences tests help us to conclude that the documented relation between private firm disclosures and public equity is not spurious, we cannot fully rule out the possibility that our proxies for private firm transparency is related to unobservable omitted correlated factors. Third, while it is reasonable to assume that a reduction in the demand for equity capital has a negative impact on public firms (and a positive impact on private firms who attract more capital) our findings cannot fully speak to the welfare implications of private firm disclosures without studying the impact on other stakeholders.

As a final thought, we think the idea that certain disclosures (e.g., private firm disclosures) can generate negative pecuniary externalities is an underexplored, but potentially important, concept in the disclosure literature. The existence of pecuniary externalities, in other settings of disclosure, can be an interesting extension to our study, and may have significant implications for optimal disclosure policy. An explicit structural estimation of the idiosyncratic vs. systematic effects of disclosure also might be a fruitful way to extend our paper. Relatedly, understanding the strategic disclosure responses by the public firms most severely affected by the negative pecuniary externalities can also extend the findings of our study potentially relevant for the strategic disclosure literature. We leave these considerations for future research. 


\section{References}

Amel-Zadeh, A., Lustermans, R., and Pieterse-Bloem, M. (2020). Sustainability and private wealth investment flows. Working Paper. 1-73.

Badertscher, B., Shroff, N., and White, H. D. (2013). Externalities of public firm presence: Evidence from private firms' investment decisions. Journal of Financial Economics, 109(3), 682-706.

Baik, B. K., Berfeld, N., and Verdi, R. (2020). Public financial statements and private firm equity financing. MIT Sloan Working Paper 1-60.

Baker, M., and Wurgler, J. (2006). Investor sentiment and the cross-section of stock returns. The Journal of Finance, 61(4), 1645-1680.

Ball, R. and Shivakumar, L. (2005) Earnings quality in UK private firms: comparative loss recognition timeliness. Journal of Accounting and Economics, 39(1), 83-128.

Barrios, J. (2021). Staggeringly problematic: A primer on staggered DiD for accounting researchers. Working Paper: $1-41$.

Barrios, J. M., Choi, J. H., Hochberg, Y. V., Kim, J., and Liu, M. (2021). Informing entrepreneurs: Public corporate disclosure and new business formation. University of Chicago, Becker Friedman Institute for Economics Working Paper, 1-58.

BASF (2016). Corporate Venture Capital at BASF - 15 Years of Connecting Start-ups and BASF. 42-48.

Berg, T., Saunders, A., Schäfer, L., and Steffen, S. (2021). Brexit and the contraction of syndicated lending. Journal of Financial Economics (forthcoming), 1-17.

Bernard, D. (2016). Is the risk of product market predation a cost of disclosure? Journal of Accounting and Economics, 62(2-3), 305-325.

Bernard, D., Blackburne, T., and Thornock, J. (2020). Information flows among rivals and corporate investment. Journal of Financial Economics, 136(3), 760-779.

Bernard, D., Burgstahler, D., and Kaya, D. (2016). Disclosure incentives and data availability for private firms: Implications for comparisons of public and private firm financial reporting quality. Working Paper: 1-49.

Bernard, D., Burgstahler, D., and Kaya, D. (2018). Size management by European private firms to minimize proprietary costs of disclosure. Journal of Accounting and Economics, 66(1), 94-122.

Bernard, D., Kaya, D., and Wertz, J. (2020). Entry and capital structure mimicking in concentrated markets: the role of incumbents' financial disclosures. Journal of Accounting and Economics (forthcoming).

Blonigen, B. A. (1997). Firm-specific assets and the link between exchange rates and foreign direct investment. The American Economic Review, 87(3), 447-465.

Bourveau, T., Chen, J. V., Elfers, F., and Pierk, J. (2020). Public peers, accounting comparability, and value relevance of private firms' financial reporting. Working Paper: 1-47.

Breuer, M. (2021). How does financial-reporting regulation affect industry-wide resource allocation? Journal of Accounting Research, 59(1), 59-110.

Breuer, M. and Breuer, P. (2020). Uneven regulation and economic reallocation: evidence from transparency regulation. Working Paper: 1-71.

Breuer, M., Hombach, K., and Müller, M. A. (2020). The economics of firms' public disclosure: Theory and evidence. Working Paper: 1-62.

Breuer, M., Leuz, C., and Vanhaverbeke, S. (2020). Reporting Regulation and Corporate Innovation. Working Paper: 1-70.

Bureau van Dijk. (2020). Orbis is a growing database of companies and other entities. Available at https://www.bvdinfo.com/en-gb/our-products/data/international/orbis (accessed December 16, 2020).

Bureau van Dijk. (2021). Detailed company information - Solutions for your organization. Available at https://www.bvdinfo.com/en-us/solutions-for-your-organization (accessed April 25, 2021).

Bushman, R. M., Piotroski, J. D., and Smith, A. J. (2004). What determines corporate transparency? Journal of Accounting Research, 42(2), 207-252.

Business Wire. (2020). Bureau van Dijk wins again for Best Entity Data Solution. Available at https://www.businesswire.com/news/home/20201210005488/en/ (accessed December 16, 2020).

Campbell, J. Y. (2006). Household finance. The Journal of Finance, 61(4):1553-1604.

Chen, S., Miao, B., and Shevlin, T. (2015). A new measure of disclosure quality: The level of disaggregation of accounting data in annual reports. Journal of Accounting Research, 53(5), 1017-1054. 
Coppola, A., Maggiori, M., Neiman, B., and Schreger, J. (2021). Redrawing the map of global capital flows: The role of cross-border financing and tax havens. Quarterly Journal of Economics (forthcoming).

Davila, E., and Korinek, A. (2016). Fire-sale externalities (No. w22444). National Bureau of Economic Research. Dechow, P., Ge, W., and Schrand, C. (2010). Understanding earnings quality: A review of the proxies, their determinants and their consequences. Journal of Accounting and Economics, 50(2-3), 344-401.

Dedman, E., and Lennox, C. (2009). Perceived competition, profitability and the withholding of information about sales and the cost of sales. Journal of Accounting and Economics, 48(2-3), 210-230.

DeFond, M., Hu, X., Hung, M., and Li, S. (2011). The impact of mandatory IFRS adoption on foreign mutual fund ownership: The role of comparability. Journal of Accounting and Economics, 51(3), 240-258.

Desai, M. A., Foley, C. F., and Forbes, K. J. (2008). Financial constraints and growth: Multinational and local firm responses to currency depreciations. The Review of Financial Studies, 21(6), 2857-2888.

Fang, V. W., Maffett, M., and Zhang, B. (2015). Foreign institutional ownership and the global convergence of financial reporting practices. Journal of Accounting Research, 53(3), 593-631.

Fernández, A., Klein, M. W., Rebucci, A., Schindler, M., and Uribe, M. (2016). Capital control measures: A new dataset. IMF Economic Review, 64(3), 548-574.

Ferracuti, E., and Stubben, S. R. (2019). The role of financial reporting in resolving uncertainty about corporate investment opportunities. Journal of Accounting and Economics, 68(2-3), 1-9.

French, K. R., and Poterba, J. M. (1991). Investor diversification and international equity markets. The American Economic Review, 81(2), 222-226.

Gabaix, X., and Koijen, R. S. (2020). In search of the origins of financial fluctuations: The inelastic markets hypothesis. Working Paper: 1-96.

Gassen, J., and Muhn, M. (2018). Financial transparency of private firms: Evidence from a randomized field experiment. Working Paper: 1-65.

Gelos G. and Wei S. (2005). Transparency and international portfolio holdings. The Journal of Finance, 60(6), 2987-3020.

Glaeser, S., and Omartian, J. D. (2021). Public firm presence, financial reporting, and the decline of US manufacturing. Kenan Institute of Private Enterprise Research Paper, 1-67.

Hart, O. D. (1975). On the optimality of equilibrium when the market structure is incomplete. Journal of Economic Theory, 11(3), 418-443.

Investment Company Institute (2020). Investment Company Fact Book $60^{\text {th }}$ Edition. 1-305.

Johnson, T. L., Kim, J., and So, E. C. (2020). Expectations management and stock returns. The Review of Financial Studies, 33(10), 4580-4626.

Kalemli-Özcan, S., Sorensen, B. E., Villegas-Sanchez, C., Volosovych, V., Yesiltas, S. (2019). How to construct nationally representative firm level data from the ORBIS global database. Tinbergen Institute Discussion Paper 15-110/IV, 1-112.

Kim, J., and Valentine, K. (2021). The innovation consequences of mandatory patent disclosures. Journal of Accounting and Economics, 71(2-3): 1-22.

Kim, J., Verdi, R. S., and Yost, B. P. (2020). Do firms strategically internalize disclosure spillovers? Evidence from cash-financed M\&As. Journal of Accounting Research, 58(5), 1249-1297.

Kwon, S., Lowry, M., and Qian, Y. (2020). Mutual fund investments in private firms. Journal of Financial Economics, 136(2), 407-443.

Lang, M., Lins, K. V., and Maffett, M. (2012). Transparency, liquidity, and valuation: International evidence on when transparency matters most. Journal of Accounting Research, 50(3), 729-774.

Lang, M., and Maffett, M. (2011). Economic effects of transparency in international equity markets: A review and suggestions for future research. Foundations and Trends in Accounting, 5(3), 175-241.

Lang, M., Maffett, M., Omartian, J. D., and Silvers, R. (2020). Regulatory cooperation and foreign portfolio investment. Journal of Financial Economics, 138(1), 138-158.

Leuz, C., Lins, K. V., and Warnock, F. E. (2009). Do foreigners invest less in poorly governed firms? The Review of Financial Studies, 22(8), 3245-3285.

Leuz, C., and Wysocki, P. D. (2016). The economics of disclosure and financial reporting regulation: Evidence and suggestions for future research. Journal of Accounting Research, 54(2), 525-622. 
Lilley, A., Maggiori, M., Neiman, B., and Schreger, J. (2020). Exchange rate reconnect. Review of Economics and Statistics (forthcoming).

Lisowsky, P., and Minnis, M. (2020). The Silent majority: Private US firms and financial reporting choices. Journal of Accounting Research, 58(3), 547-588.

Maffett, M. (2012). Financial reporting opacity and informed trading by international institutional investors. Journal of Accounting and Economics, 54(2-3), 201-220.

Maggiori, M., Neiman, B., and Schreger, J. (2020). International currencies and capital allocation. Journal of Political Economy, 128(6), 2019-2066.

Makarov, I., and Schoar, A. (2020). Trading and arbitrage in cryptocurrency markets. Journal of Financial Economics, 135(2), 293-319.

Mayer, T. and Zignago, S. (2011). Notes on CEPII's distances measures: the GeoDist Database. CEPII Working Paper, 2011-25.

Melitz, J., and Toubal, F. (2014). Native language, spoken language, translation and trade. Journal of International Economics, 93(2), 351-363.

Merton, R. C. (1987). A simple model of capital market equilibrium with incomplete information. The Journal of Finance, 42(3), 483-510.

Minnis, M. (2011). The Value of Financial Statement Verification in Debt Financing: Evidence from Private U.S. Firms. Journal of Accounting Research, 49(2): 457-506.

Minnis, M., and Shroff, N. (2017). Why regulate private firm disclosure and auditing? Accounting and Business Research, 47(5), 473-502.

Moody's (2018). 2017 Annual Report. URL.

Moody's (2021). 2020 Annual Report. URL.

Napier, C. (2010). The history of financial reporting in the United Kingdom. Published as Chapter 13, "United Kingdom", in Gary Previts, Peter Walton \& Peter Wolnizer (eds) A Global History of Accounting, Financial Reporting and Public Policy (Bingley: Emerald, 2010), pp. 243-273.

Oberhuber, A. (2018). FLASH: Nestlé enters agreement to sell Starbucks coffee - fighting back. MainFirst Bank. May 07, 2018, available from Investext (accessed August 14, 2021).

Pinto Ribeiro, S., Menghinello, S., Backer, K. D. (2010). The OECD ORBIS Database: Responding to the Need for Firm-Level Micro-Data in the OECD." OECD Statistics Working Papers 2010/01, 1-33.

Piotroski, J. and Srinivasan S. (2008). Regulation and bonding: The Sarbanes-Oxley Act and the flow of international listings. Journal of Accounting Research 46(2): 383-425.

Preqin (2020). Preqin global 2020 private equity \& venture capital report. 1-129.

Shroff, N. (2016). Discussion of "Is the risk of product market predation a cost of disclosure?" Journal of Accounting and Economics, 62(2-3), 326-332.

Siriwardane, E. N. (2019). Limited investment capital and credit spreads. The Journal of Finance, 74(5), 23032347.

Stiglitz, J. E. (1981). The allocation role of the stock market: Pareto optimality and competition. The Journal of Finance, 36(2), 235-251.

Stiglitz, J. E. (1982). The inefficiency of the stock market equilibrium. Review of Economic Studies, 49(2), 241261.

Suárez Serrato, J. C., Zidar, O. (2016). Who benefits from state corporate tax cuts? A local labor markets approach with heterogeneous firms. American Economic Review, 106(9), 2582-2624.

World Bank. (2020). Listed domestic companies, total. World Development Indicators, available at https://data.worldbank.org/indicator/CM.MKT.LDOM.NO (accessed December 16, 2020). 


\section{Figure 1. Private Firm Transparency and Foreign Portfolio Investment in Public Equity by Country}

Panel A. Average Foreign Portfolio Investment in Public Equity by Investee Country

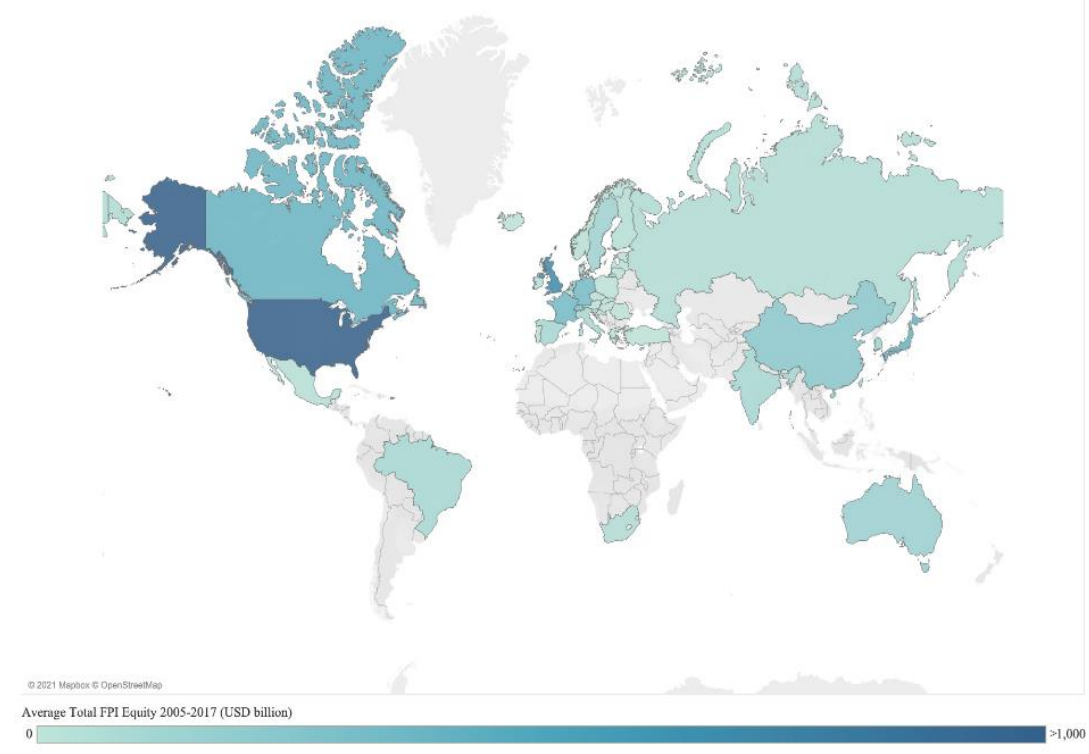

Panel B. Average Private Firm Transparency by Investee Country

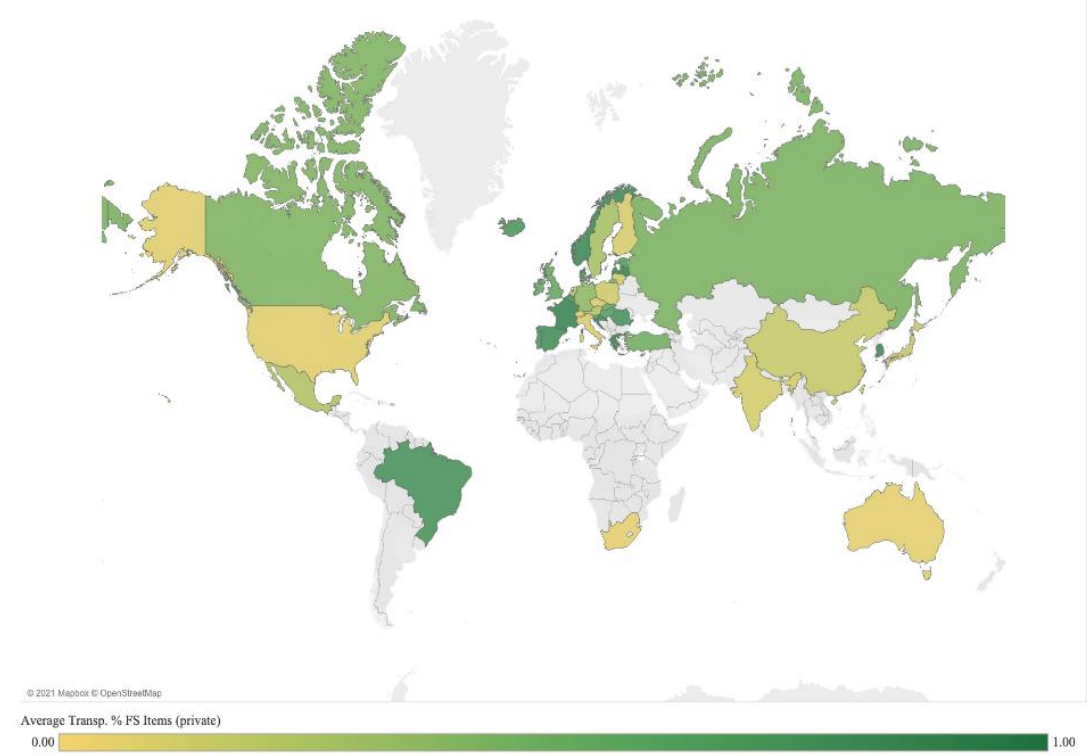

Notes: The figure illustrates variation in our main constructs of interest across sample countries. In Panel A, we depict the total foreign portfolio investment stock in an investee country's public firms held by global investors (in USD million). In Panel B, we aggregate private firm financial transparency at the investee country level and average the resulting measure over the sample period. The resulting measure is averaged over the sample period. 
Figure 2. Private Firm Transparency and Foreign Portfolio Investment in Public Equity: Graphical Evidence

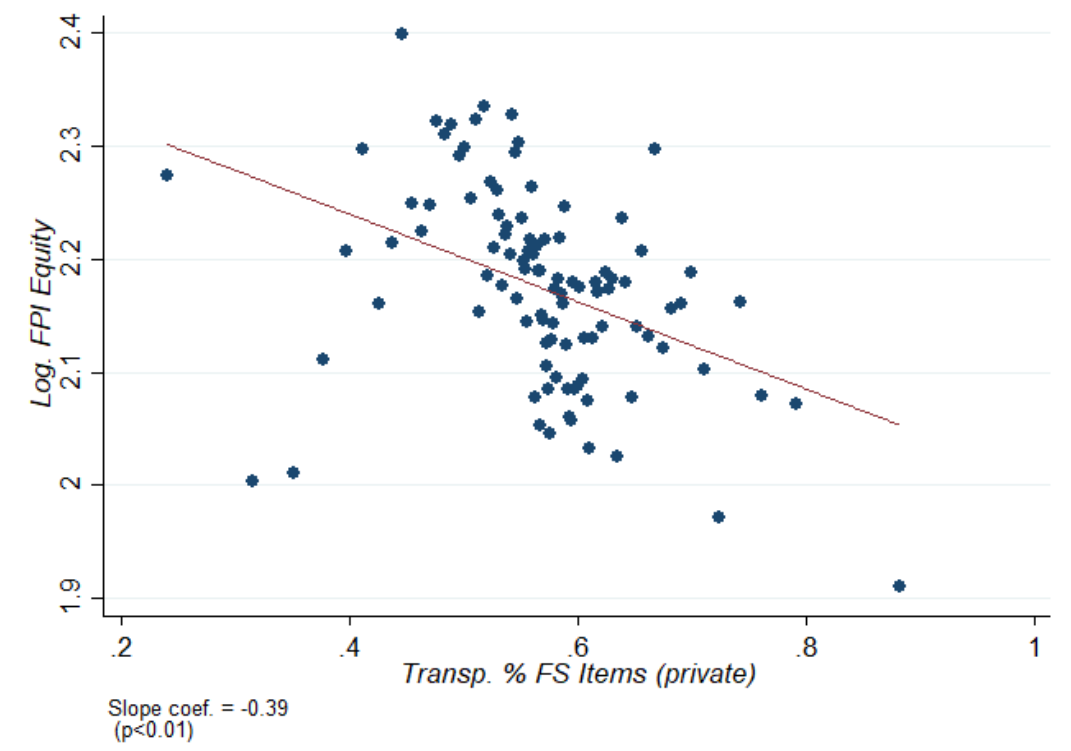

Notes: This figure shows binned scatterplots that illustrate the relationship between foreign portfolio investment in public equity, Log. FPI Equity, and private firm financial transparency, Transp. \% FS Items (private). Observations are sorted into percentile bins based on their value of Transp. \% FS Items (private), measured using financial statement information in fiscal year $\mathrm{t}-2$. To filter out confounding effects when plotting the relationship between Log. FPI Equity and Transp. \% FS Items (private), we residualize these variables against investor-investee-industry fixed effects, year fixed effects, and a set of control variables as discussed in Section 3.3. Detailed definitions of all variables are provided in Appendix B. 
Figure 3. Private Firm Transparency and Foreign Investment in Private Firms: Graphical Evidence

Panel A. Predicted Foreign Portfolio Investments (FPI) in Public Equity and Private Firm M\&A Investments

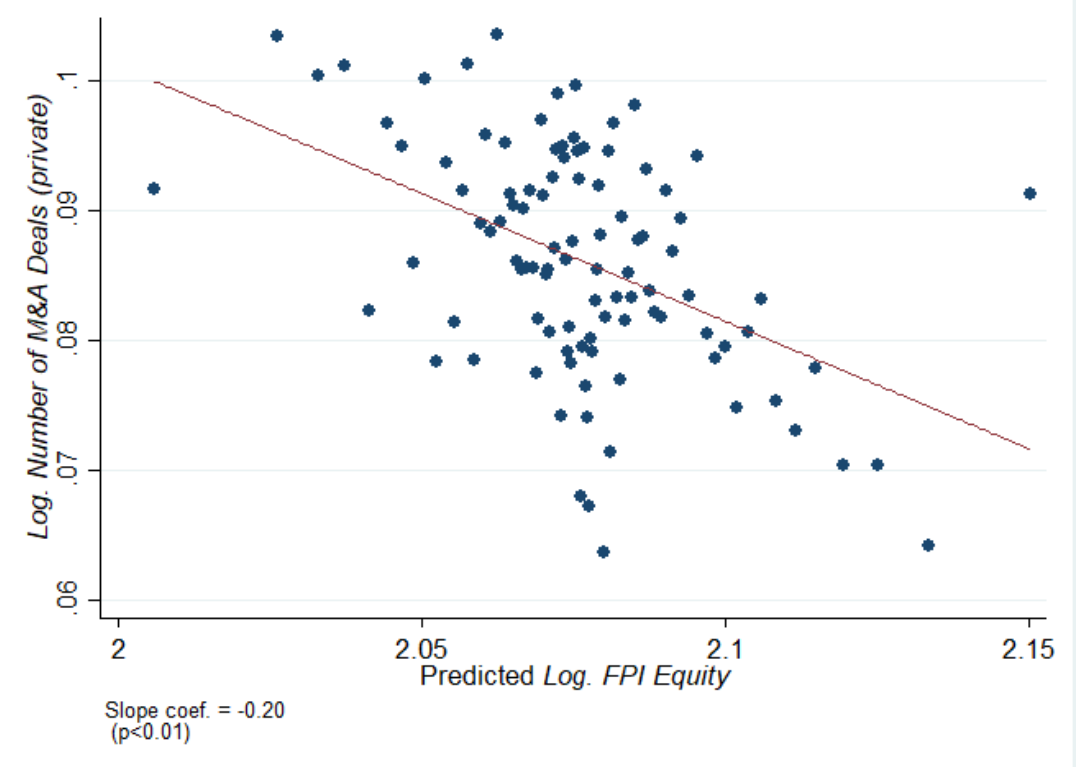

Panel B. Private Firm Transparency and Private Firm M\&A Investments

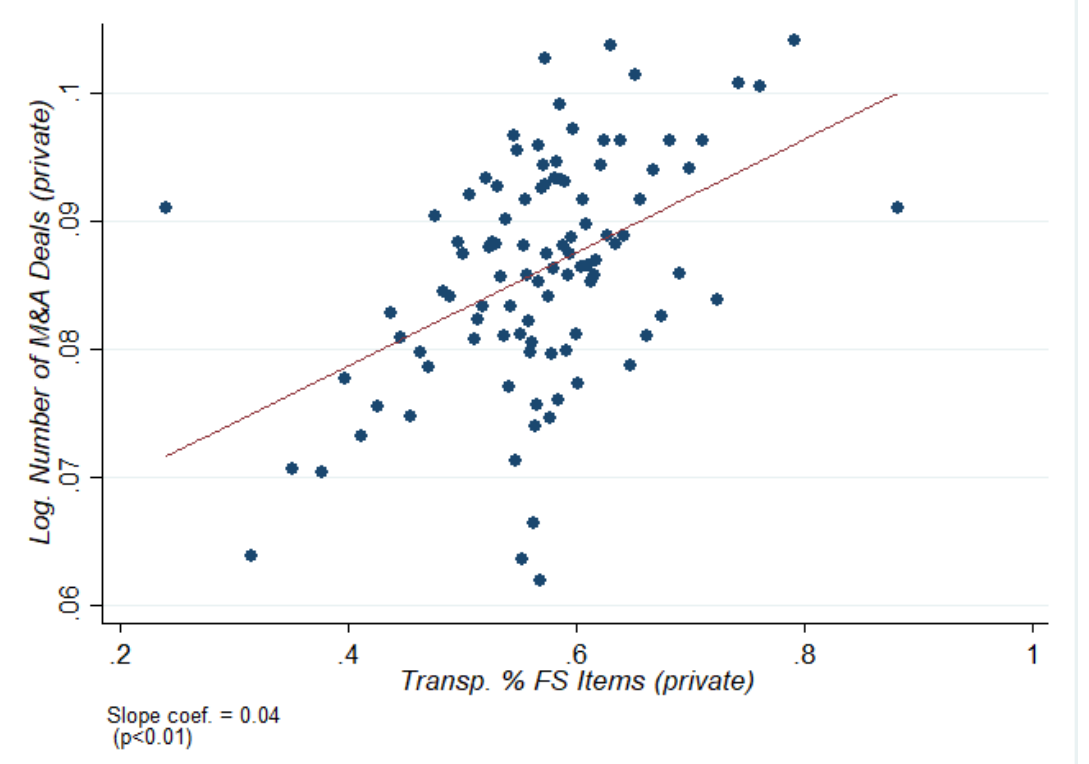

Notes: This figure shows binned scatterplots that illustrate the relationship between private firm transparency and foreign investment in private firms. Panel A plots the relationship between predicted foreign portfolio investment in public equity (Predicted Log. FPI) and M\&A transactions with private target firms (Log. Number of M\&A Deals (private)). Observations are sorted into percentile bins based on their value of Predicted Log. FPI, measured using the fitted values from the regression results using equation (1). Panel B plots the relationship between private firm financial transparency (Transp. \% FS Items (private)) and M\&A transactions with private target firms (Log. Number of M\&A Deals (private)). Observations are sorted into percentile bins based on their value of Transp. \% FS Items (private), measured using financial statement information in fiscal year $\mathrm{t}-2$. To filter out confounding effects when plotting the relationship between the independent and dependent variables, we residualize these variables against investor-investee-industry fixed effects, year fixed effects, and a set of control variables as discussed in Section 3.3. Detailed definitions of all variables are provided in Appendix B. 
Figure 4. Cumulative Dynamic Effects of Private Firm Transparency on Log. FPI Equity

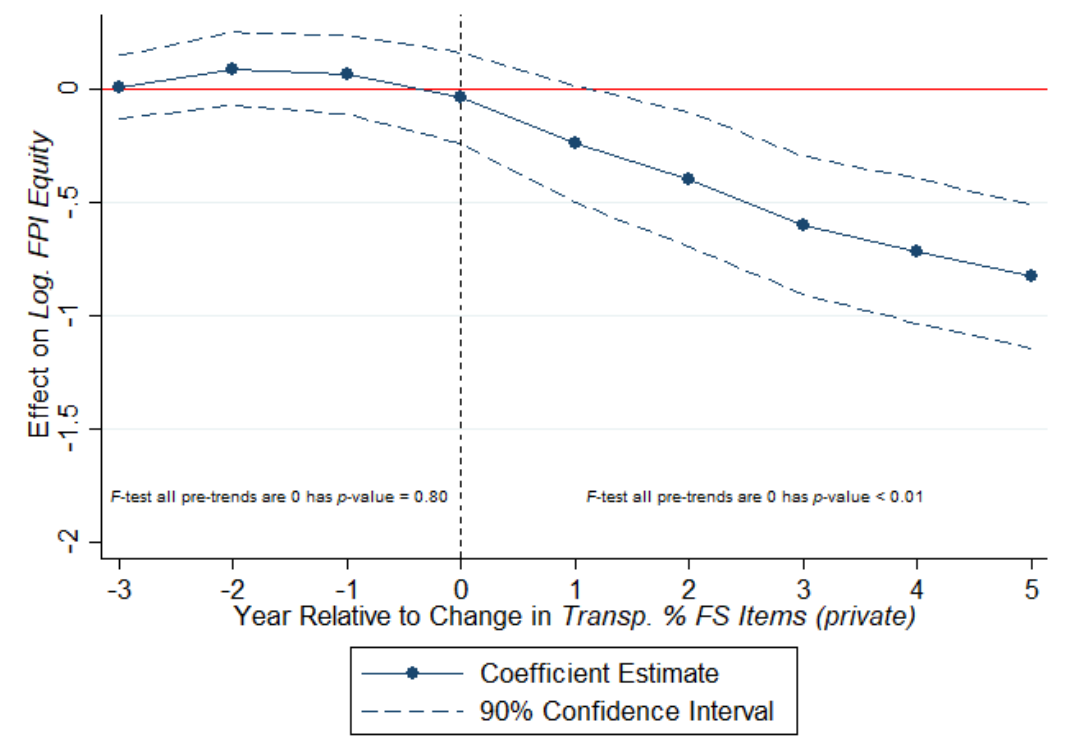

Notes: This figure shows the cumulative dynamic effects of private firm financial transparency, Transp. \% FS Items (private), on foreign portfolio investment in public equity, Log. FPI Equity. The figure plots results from estimating a distributed lag models. In the x-axis, the figure shows the sum of the point estimates of Transp. \% FS Items (private) measured at different points in time on Log. FPI Equity. 90 percent confidence intervals for the estimates are reported by the dashed lines. For example, the cumulative point estimate of 0.03 together with the confidence band overlapping the red dashed line of 0 in the relative event year t- 1 imply that the sum of the effects of private firm transparency as of fiscal year 2014, 2015, and 2016 did not have a statistically significant effect on foreign portfolio investment in public equity in 2013. The graphs also report the p-values for F-tests that the three lead values of the private firm transparency measure and that the current and five lag values are jointly equal to zero. Point estimates are derived from a regression including control variables, investor-investee-industry fixed effects, and year fixed effects. Detailed definitions of all variables are provided in Appendix B. 
Figure 5. Country-level Shocks to Private Firm Transparency and Log. FPI Equity Panel A. Staggered BvD Office Opening

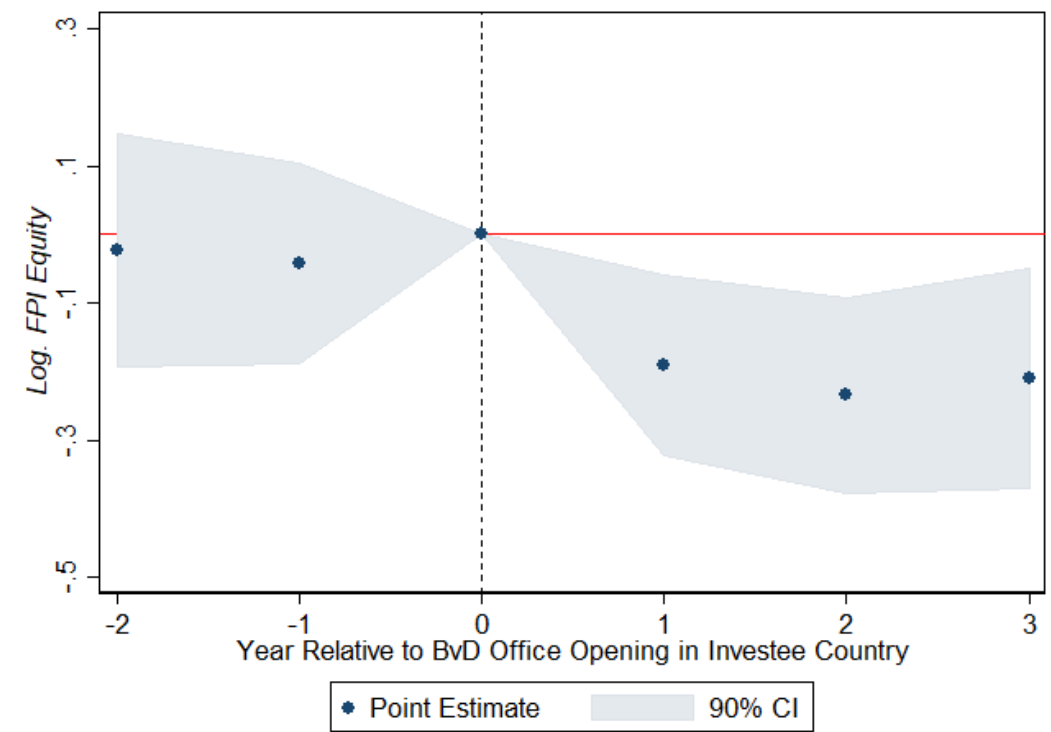

Panel B. Staggered Electronic Business Register Implementation

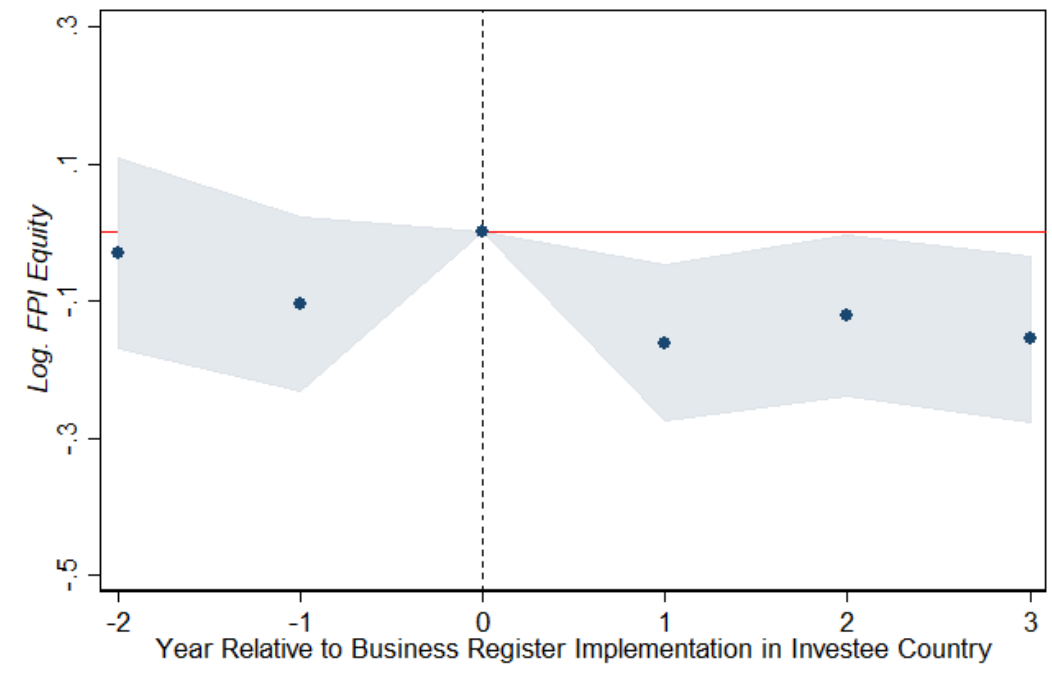

- Point Estimate $\quad 90 \% \mathrm{Cl}$

Notes: This figure shows changes foreign portfolio investment in public equity, Log. FPI Equity, measured by difference-indifferences coefficients from the staggered openings of BvD offices in investee countries (Panel A) or the implementation of electronic business registers in investee countries (Panel B). The unit of observation is at the investor country, investee country, investee industry, and year level. In Panel A, an observation is treated once BvD opens an office in the investee country in a given year. In Panel B, an observation is treated in years after the implementation of electronic business registers in the investee country in a given year. The coefficient estimates (blue circles) and their $90 \%$ confidence intervals depict values in Log. FPI in a given year relative to the year in the office opening (Panel A) of before the business register implementation (Panel B). Point estimates are derived from a regression including control variables and fixed effects as in Column (2) of Panels A and B in Table 7, such that control observations are not yet treated or already treated observations in the same investee-year. Detailed definitions of all variables are provided in Appendix B. The BvD office opening and business register implementation dates are provided in Tables A3 and A5 of Appendix C. 
Panel A. Investor Countries

Figure 6. Jackknife Robustness Tests

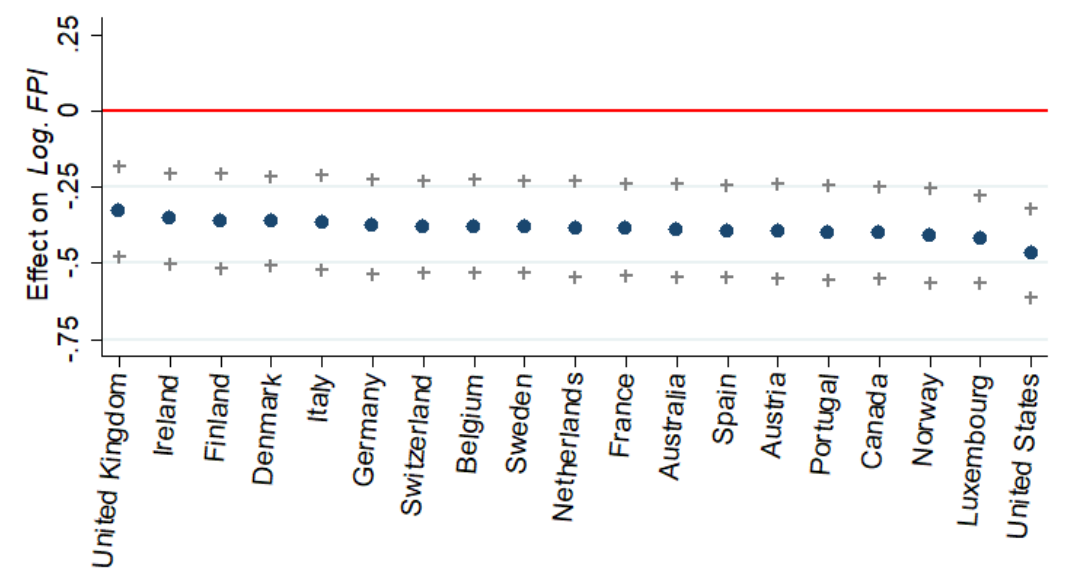

Excluded Investor Country

- Coefficient on Transp. \% FS Items (private)

$+90 \%$ Confidence Interval

\section{Panel B. Investee Countries}

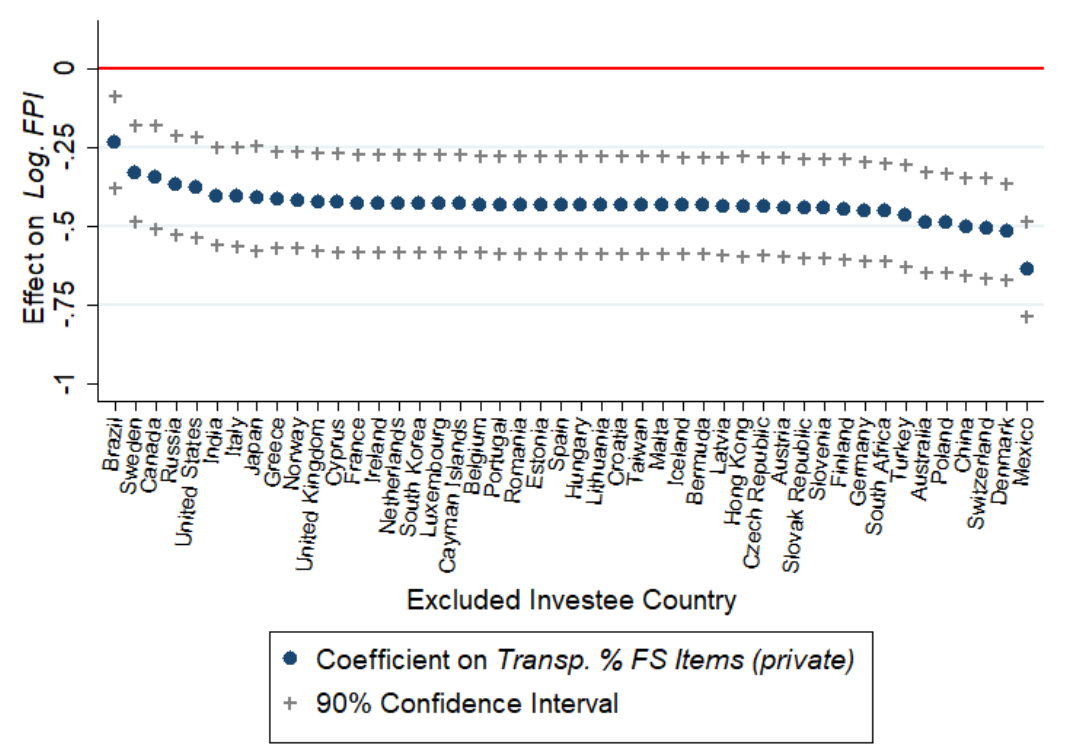

Notes: This figure shows the coefficients estimates and $90 \%$ confidence intervals from regressing foreign portfolio investment in public equity, Log. FPI Equity, on private firm transparency, Transp. \% FS Items (private), when excluding one investor or investee country from the analysis each time. Panel A plots the regression estimates when the investor country corresponding to the $\mathrm{x}$-axis label is excluded from the sample. Point estimates are derived from a regression including control variables, investor-investeeindustry and year fixed effects, and the two-tailed $90 \%$ confidence intervals are based on standard errors clustered at the investeeindustry-year level. Panel B plots the regression estimates when the investee country corresponding to the x-axis label is excluded from the sample. Point estimates are derived from a regression including control variables and investor-investee-industry fixed effects, and the two-tailed $90 \%$ confidence intervals are based on standard errors clustered at the investee-industry-year level. Detailed definitions of all variables are provided in Appendix B. 
Table 1. Descriptive Statistics by Countries and Industries

\begin{tabular}{lcc}
\hline Panel A. Investor Countries & & \\
\hline & $\begin{array}{c}\text { Total FPI Equity } \\
\text { in 2017 (USD billion) }\end{array}$ & $\begin{array}{c}\text { Average Total FPI Equity } \\
\text { 2005-2017 (USD billion) }\end{array}$ \\
\cline { 2 - 3 } & $(1)$ & $(2)$ \\
\hline United States & 12416.96 & 6607.38 \\
Luxembourg & 1201.07 & 802.79 \\
United Kingdom & 775.71 & 509.56 \\
Canada & 593.77 & 389.15 \\
Ireland & 581.55 & 260.82 \\
Germany & 216.71 & 148.77 \\
Sweden & 209.78 & 150.48 \\
France & 195.38 & 161.24 \\
Switzerland & 164.12 & 89.31 \\
Australia & 156.46 & 160.07 \\
Norway & 56.70 & 36.03 \\
Netherlands & 54.43 & 36.29 \\
Finland & 44.71 & 26.47 \\
Denmark & 42.61 & 36.58 \\
Spain & 42.34 & 34.81 \\
Italy & 37.33 & 38.25 \\
Belgium & 21.94 & 32.01 \\
Austria & 13.88 & 11.44 \\
Portugal & 1.60 & 2.84 \\
\hline
\end{tabular}


Table 1. [Continued]

\begin{tabular}{|c|c|c|c|}
\hline \multicolumn{4}{|l|}{ Panel B. Investee Countries } \\
\hline & $\begin{array}{c}\text { Total FPI Equity } \\
\text { in } 2017 \text { (USD billion) }\end{array}$ & $\begin{array}{l}\text { Average Total FPI Equity } \\
\text { 2005-2017 (USD billion) }\end{array}$ & $\begin{array}{l}\text { Average Transp. } \% \\
\text { FS Items (private) }\end{array}$ \\
\hline & $(1)$ & $(2)$ & $(3)$ \\
\hline Greece & 1.84 & 2.62 & 0.90 \\
\hline Cayman Islands & 0.00 & 0.06 & 0.88 \\
\hline Korea, Republic of & 208.49 & 111.29 & 0.85 \\
\hline Croatia & 0.00 & 0.00 & 0.84 \\
\hline Bermuda & 0.00 & 0.00 & 0.82 \\
\hline Malta & 0.01 & 0.01 & 0.81 \\
\hline France & 514.24 & 327.05 & 0.80 \\
\hline Norway & 22.34 & 18.21 & 0.79 \\
\hline Spain & 142.40 & 91.67 & 0.77 \\
\hline Belgium & 20.61 & 37.03 & 0.76 \\
\hline Latvia & 0.00 & 0.00 & 0.76 \\
\hline Brazil & 94.69 & 91.92 & 0.74 \\
\hline Romania & 0.00 & 0.00 & 0.74 \\
\hline Portugal & 5.31 & 3.86 & 0.74 \\
\hline Iceland & 0.00 & 0.00 & 0.72 \\
\hline Italy & 130.42 & 78.43 & 0.72 \\
\hline Estonia & 0.03 & 0.05 & 0.67 \\
\hline Denmark & 78.68 & 34.08 & 0.65 \\
\hline Luxembourg & 3.19 & 2.59 & 0.62 \\
\hline Japan & 651.81 & 376.13 & 0.61 \\
\hline Slovenia & 0.10 & 0.08 & 0.60 \\
\hline Hungary & 0.00 & 0.04 & 0.60 \\
\hline Sweden & 196.60 & 121.42 & 0.60 \\
\hline Ireland & 60.86 & 23.40 & 0.50 \\
\hline China & 455.54 & 220.25 & 0.50 \\
\hline Finland & 36.01 & 28.19 & 0.49 \\
\hline United Kingdom & 1008.78 & 666.56 & 0.49 \\
\hline Slovakia & 0.00 & 0.00 & 0.48 \\
\hline Germany & 505.13 & 318.53 & 0.42 \\
\hline Austria & 10.76 & 6.16 & 0.40 \\
\hline Turkey & 0.15 & 2.49 & 0.36 \\
\hline Canada & 526.15 & 384.04 & 0.32 \\
\hline Russian Federation & 50.46 & 45.11 & 0.26 \\
\hline Netherlands & 309.50 & 183.11 & 0.25 \\
\hline Czech Republic & 0.00 & 0.00 & 0.21 \\
\hline Cyprus & 0.76 & 0.80 & 0.14 \\
\hline Poland & 0.13 & 0.17 & 0.12 \\
\hline Lithuania & 0.01 & 0.01 & 0.11 \\
\hline Taiwan, Province of China & 169.66 & 91.92 & 0.09 \\
\hline India & 175.87 & 96.31 & 0.09 \\
\hline Hong Kong & 90.55 & 56.21 & 0.08 \\
\hline Mexico & 0.17 & 27.35 & 0.07 \\
\hline South Africa & 74.76 & 48.21 & 0.07 \\
\hline Switzerland & 401.71 & 269.67 & 0.07 \\
\hline United States & 10686.39 & 5592.10 & 0.06 \\
\hline Australia & 192.93 & 148.71 & 0.04 \\
\hline
\end{tabular}


Table 1. [Continued]

Panel C. Investee-Industries

\begin{tabular}{|c|c|c|c|}
\hline & $\begin{array}{c}\text { Total FPI Equity } \\
\text { in } 2017 \text { (USD billion) }\end{array}$ & $\begin{array}{l}\text { Average Total FPI Equity } \\
2005-2017 \text { (USD billion) }\end{array}$ & $\begin{array}{l}\text { Average Transp. \% } \\
\text { FS Items (private) }\end{array}$ \\
\hline & $(1)$ & $(2)$ & (3) \\
\hline Manufacturing & 6492.19 & 3735.51 & 0.53 \\
\hline Finance, Insurance, Real Estate & 3929.95 & 2133.72 & 0.51 \\
\hline Information & 2067.84 & 1036.48 & 0.47 \\
\hline Arts, Entertainment, Hotels, and Dining & 270.09 & 136.87 & 0.47 \\
\hline Transportation and Warehousing & 507.29 & 272.03 & 0.45 \\
\hline Business Services & 810.62 & 438.82 & 0.45 \\
\hline Other & 0.15 & 0.97 & 0.44 \\
\hline Wholesale and Retail Trade & 1128.80 & 616.70 & 0.40 \\
\hline Education, Health, Public Administration, and Other Services & 46.67 & 36.25 & 0.39 \\
\hline Agriculture, Mining, Utilities, and Construction & 1573.42 & 1193.03 & 0.39 \\
\hline
\end{tabular}


Table 1. [Continued]

\begin{tabular}{|c|c|c|c|}
\hline \multicolumn{4}{|c|}{ Panel D. Determinants of Transp. \% FS Items (private) } \\
\hline & \multicolumn{3}{|c|}{ Transp. $\%$ FS Items (private, $t+1$ ) } \\
\hline & (1) & (2) & (3) \\
\hline \multicolumn{4}{|l|}{ Foreign Demand Factors } \\
\hline Log. FPI Equity & $\begin{array}{l}-0.001 \\
(-0.34)\end{array}$ & $\begin{array}{l}-0.002 \\
(-0.69)\end{array}$ & $\begin{array}{l}-0.003 \\
(-1.07)\end{array}$ \\
\hline$F D I(\%$ of $G D P)$ & $\begin{array}{l}0.000^{*} \\
(1.66)\end{array}$ & $\begin{array}{l}0.000^{*} \\
(1.95)\end{array}$ & $\begin{array}{l}0.000 \\
(1.05)\end{array}$ \\
\hline \multicolumn{4}{|l|}{ Domestic Country Factors } \\
\hline Log. Country GDP & $\begin{array}{c}0.057 * * * \\
(3.59)\end{array}$ & $\begin{array}{c}0.051 * * * \\
(3.26)\end{array}$ & $\begin{array}{c}0.053 * * \\
(2.15)\end{array}$ \\
\hline Log. Population & $\begin{array}{c}-0.059 * * * \\
(-5.20)\end{array}$ & $\begin{array}{c}-0.057 * * * \\
(-5.19)\end{array}$ & $\begin{array}{l}0.003 \\
(0.02)\end{array}$ \\
\hline \multicolumn{4}{|l|}{ Domestic Industry Factors } \\
\hline Private Firm Reports / Industry GDP & $\begin{array}{l}0.025 \\
(0.70)\end{array}$ & $\begin{array}{l}0.035 \\
(1.04)\end{array}$ & $\begin{array}{l}-0.013 \\
(-0.57)\end{array}$ \\
\hline Transp. \% FS Items (public) & $\begin{array}{c}0.588 * * * \\
(5.46)\end{array}$ & $\begin{array}{c}0.597 * * * \\
(5.75)\end{array}$ & $\begin{array}{l}0.001 \\
(0.02)\end{array}$ \\
\hline Log. No. Public Firms & $\begin{array}{c}0.058 * * * \\
(7.85)\end{array}$ & $\begin{array}{c}0.063^{* * * *} \\
(8.79)\end{array}$ & $\begin{array}{l}-0.022 \\
(-1.45)\end{array}$ \\
\hline Log. No. Private Firms & $\begin{array}{c}-0.071 * * * \\
(-13.32)\end{array}$ & $\begin{array}{c}-0.063 * * * \\
(-11.81)\end{array}$ & $\begin{array}{c}-0.080 * * * \\
(-17.96)\end{array}$ \\
\hline$R O A$ & $\begin{array}{c}-0.559 * * * \\
(-3.31)\end{array}$ & $\begin{array}{c}-0.716^{* * * *} \\
(-4.17)\end{array}$ & $\begin{array}{l}-0.013 \\
(-0.13)\end{array}$ \\
\hline Revenue Growth & $\begin{array}{c}0.040 * * * \\
(3.21)\end{array}$ & $\begin{array}{l}-0.017 \\
(-1.35)\end{array}$ & $\begin{array}{l}-0.012^{*} \\
(-1.66)\end{array}$ \\
\hline Log. Median Size (Total Assets) & $\begin{array}{c}-0.075 * * * \\
(-15.85)\end{array}$ & $\begin{array}{c}-0.070 * * * \\
(-15.23)\end{array}$ & $\begin{array}{c}-0.032 * * * \\
(-6.46)\end{array}$ \\
\hline Obs. & 4,666 & 4,666 & 4,666 \\
\hline Adj. R2 & 0.334 & 0.382 & 0.796 \\
\hline Investee-Industry FE & No & No & Yes \\
\hline Year FE & No & Yes & Yes \\
\hline
\end{tabular}

Notes: This table presents information on our main empirical constructs of interest. In Panel A, we present the FPI holdings by investors domiciled in a given country. Column (1) presents total FPI held across all investee countries and industries as of 2017. Column (2) presents the average total holdings per year in the sample period. In Panel B, we present FPI holdings by all foreign investors in a given country. Column (1) presents total FPI held across all investee countries and industries as of 2017. In Column (3), we present aggregate private firm financial transparency at the investee country level (averaged over the sample period consistent with Panel A of Figure 1). In Panel C, we present FPI holdings by all foreign investors across all investee countries in a given industry. Column (1) presents total FPI held across all investee countries and industries as of 2017. In Column (3), we present aggregate private firm financial transparency at the industry level (averaged over the sample period and over all sample countries). Panel D presents results from aggregated investee-industry-year level regressions of private firm transparency on lagged foreign demand factors, lagged investee country-level macroeconomic factors and lagged investee country-industry-level factors. The dependent variable of interest Transp. \% FS Items (private) is defined as the number of non-missing financial statement line items disclosed by private firms, divided by the total number of line items that these private firms can hypothetically disclose conditional on each private firm preparing and publishing financial statements (as proxied by the observability of at least one financial statement item). Column (2) includes year fixed effects. Column (3) includes investee-industry and year fixed effects. The t-statistics reported below the coefficient estimates in parentheses are computed based on standard errors clustered by investee-industry. ***, ***,* indicates statistical significance at 1\%,5\%, and 10\%, respectively (two-tailed). Variables definitions are in Appendix B. 
Table 2. Descriptive Statistics and Correlations

\begin{tabular}{|c|c|c|c|c|c|c|c|c|}
\hline \multicolumn{9}{|l|}{ Panel A. Summary Statistics } \\
\hline & Obs. & Mean & SD & $\mathrm{P} 1$ & $\mathrm{P} 25$ & Median & P75 & P99 \\
\hline \multicolumn{9}{|l|}{ Dependent Variables } \\
\hline Log. FPI Equity & 73,423 & 2.18 & 2.94 & 0.00 & 0.00 & 0.00 & 4.55 & 9.89 \\
\hline Log. Number of M\&A Deals (public) & 73,423 & 0.00 & 0.04 & 0.00 & 0.00 & 0.00 & 0.00 & 0.00 \\
\hline Log. Number of M\&A Deals (private) & 73,423 & 0.09 & 0.37 & 0.00 & 0.00 & 0.00 & 0.00 & 2.08 \\
\hline Log. Avg. M\&A Deal Value (public) & 73,423 & 0.04 & 0.81 & 0.00 & 0.00 & 0.00 & 0.00 & 0.00 \\
\hline Log. Avg. M\&A Deal Value (private) & 73,423 & 0.64 & 3.36 & 0.00 & 0.00 & 0.00 & 0.00 & 19.31 \\
\hline Log. Avg. M\&A Revenue (public) & 73,423 & 0.04 & 0.88 & 0.00 & 0.00 & 0.00 & 0.00 & 0.00 \\
\hline Log. Avg. M\&A Revenue (private) & 73,423 & 0.95 & 3.98 & 0.00 & 0.00 & 0.00 & 0.00 & 19.40 \\
\hline Log. Number of VC Deals & 73,423 & 0.01 & 0.12 & 0.00 & 0.00 & 0.00 & 0.00 & 0.00 \\
\hline Log. Avg. VC Deal Value & 73,423 & 0.11 & 1.37 & 0.00 & 0.00 & 0.00 & 0.00 & 0.00 \\
\hline Log. Avg. VC Revenue & 73,423 & 0.07 & 1.06 & 0.00 & 0.00 & 0.00 & 0.00 & 0.00 \\
\hline \multicolumn{9}{|l|}{ Independent Variables } \\
\hline Transp. \% FS Items (private) & 73,423 & 0.57 & 0.27 & 0.04 & 0.38 & 0.66 & 0.79 & 0.91 \\
\hline Transp. \% BS Items (private) & 73,423 & 0.39 & 0.18 & 0.00 & 0.26 & 0.47 & 0.53 & 0.56 \\
\hline Transp. \% BS Items (public) & 73,423 & 0.94 & 0.08 & 0.63 & 0.94 & 0.97 & 0.99 & 1.00 \\
\hline Transp. \% PL Items (private) & 73,423 & 0.13 & 0.08 & 0.00 & 0.04 & 0.15 & 0.20 & 0.26 \\
\hline Transp. \% PL Items (public) & 73,423 & 0.86 & 0.12 & 0.54 & 0.77 & 0.87 & 0.96 & 1.00 \\
\hline Transp. \% Footnote Items (private) & 73,423 & 0.05 & 0.03 & 0.00 & 0.02 & 0.04 & 0.08 & 0.12 \\
\hline Transp. \% Footnote Items (public) & 73,423 & 0.52 & 0.15 & 0.15 & 0.41 & 0.53 & 0.63 & 0.79 \\
\hline Transp. \% FS Items (public) & 73,423 & 0.84 & 0.07 & 0.57 & 0.82 & 0.86 & 0.89 & 0.94 \\
\hline Log. No. Public Firms & 73,423 & 3.65 & 1.60 & 0.69 & 2.48 & 3.47 & 4.70 & 7.87 \\
\hline Log. No. Private Firms & 73,423 & 8.58 & 2.83 & 1.61 & 6.55 & 9.22 & 10.75 & 13.11 \\
\hline Log. Median Size (Total Assets) & 73,423 & 14.39 & 2.65 & 9.90 & 12.56 & 13.65 & 16.18 & 20.84 \\
\hline$R O A$ & 73,423 & 0.05 & 0.04 & -0.03 & 0.03 & 0.05 & 0.07 & 0.19 \\
\hline Revenue Growth & 73,423 & 0.12 & 0.29 & -0.59 & -0.05 & 0.08 & 0.24 & 1.14 \\
\hline Log. Country GDP & 73,423 & 27.08 & 1.78 & 22.18 & 26.29 & 27.27 & 28.26 & 30.49 \\
\hline Log. Population & 73,423 & 16.80 & 2.16 & 10.95 & 15.56 & 16.96 & 18.06 & 21.03 \\
\hline$F D I(\%$ of $G D P)$ & 73,423 & 26.06 & 139.73 & -5.68 & 1.29 & 2.58 & 5.30 & 590.91 \\
\hline \multicolumn{9}{|l|}{ Cross-sectional Variables } \\
\hline High Capital Control & 73,423 & 0.08 & 0.27 & 0.00 & 0.00 & 0.00 & 0.00 & 1.00 \\
\hline Currency Appreciation & 73,423 & 0.10 & 0.29 & 0.00 & 0.00 & 0.00 & 0.00 & 1.00 \\
\hline High Language Distance & 73,423 & 0.05 & 0.22 & 0.00 & 0.00 & 0.00 & 0.00 & 1.00 \\
\hline High Physical Distance & 73,423 & 0.10 & 0.30 & 0.00 & 0.00 & 0.00 & 0.00 & 1.00 \\
\hline Post * BvD Office (Investee) & 73,423 & 0.51 & 0.50 & 0.00 & 0.00 & 1.00 & 1.00 & 1.00 \\
\hline
\end{tabular}


Table 2. [Continued]

\section{Panel B. Pearson Correlations}

Log. FPI Equity

Transp. \% FS Items (private)

Transp. \% FS Items (public)

Log. No. Public Firms

Log. No. Private Firms

Log. Median Size (Total Assets)

$R O A$

Revenue Growth

Log. M\&A Deal Value (private)

Log. VC Deal Value
(1)

(1)

(2) $-0.082 * * *$

(3) $-0.047 * * *$

(4) $0.464 * * *$

(5) $0.192 * * *$

(6) $0.098 * * *$

(7) $0.052 * * *$

(8) $-0.044 * * *$

(9) $0.176 * * *$

(10) $0.100 * * *$
(2)

(3)

(4)

(5)

(6)

(7)

(8)

(9)

(10)

ese the full regression sample. The unit of observation is at the investor country, investee country, investee industry, and year level.

The sample period is 2005-2017. Panel A presents summary statistics on the variables used in the regression analyses. Panel B presents Pearson correlations between the outcome variables, private firm transparency, and a set of control variables. Detailed definitions of all variables are provided in Appendix B. 
Table 3. Private Firm Transparency and Foreign Portfolio Investment in Public Equity: Regression Results Panel A. Entire Private Firm F/S

\begin{tabular}{|c|c|c|c|}
\hline & \multicolumn{3}{|c|}{ Log. FPI Equity } \\
\hline & (1) & (2) & (3) \\
\hline Transp. \% FS Items (private) & $\begin{array}{c}-0.374 * * * \\
(-6.65)\end{array}$ & $\begin{array}{c}-0.433 * * * \\
(-4.62)\end{array}$ & $\begin{array}{c}-0.387 * * * \\
(-4.22)\end{array}$ \\
\hline Transp. \% FS Items (public) & & $\begin{array}{c}0.723 * * * \\
(3.79)\end{array}$ & $\begin{array}{c}0.573 * * * \\
(3.05)\end{array}$ \\
\hline Log. No. Public Firms & & $\begin{array}{c}0.149 * * * \\
(3.92)\end{array}$ & $\begin{array}{c}0.078^{*} \\
(1.79)\end{array}$ \\
\hline Log. No. Private Firms & & $\begin{array}{c}-0.044 * * * \\
(-2.99)\end{array}$ & $\begin{array}{c}-0.053 * * * \\
(-3.65)\end{array}$ \\
\hline Log. Median Size (Total Assets) & & $\begin{array}{l}-0.006 \\
(-0.38)\end{array}$ & $\begin{array}{l}0.004 \\
(0.29)\end{array}$ \\
\hline$R O A$ & & $\begin{array}{c}2.041 * * * \\
(5.24)\end{array}$ & $\begin{array}{c}1.992 * * * \\
(5.20)\end{array}$ \\
\hline Revenue Growth & & $\begin{array}{l}-0.020 \\
(-0.61)\end{array}$ & $\begin{array}{c}0.056^{*} \\
(1.70)\end{array}$ \\
\hline Log. Country GDP & & $\begin{array}{c}0.524 * * * \\
(7.00)\end{array}$ & $\begin{array}{c}0.659 * * * \\
(7.88)\end{array}$ \\
\hline Log. Population & & $\begin{array}{c}-0.633^{*} \\
(-1.77)\end{array}$ & $\begin{array}{c}-1.512 * * * \\
(-3.97)\end{array}$ \\
\hline$F D I(\%$ of $G D P)$ & & $\begin{array}{l}0.000 \\
(0.80) \\
\end{array}$ & $\begin{array}{l}0.000^{*} \\
(1.95) \\
\end{array}$ \\
\hline Obs. & 73,423 & 73,423 & 73,423 \\
\hline Adj. R2 & 0.870 & 0.871 & 0.873 \\
\hline Investor-Investee-Industry FE & Yes & Yes & Yes \\
\hline Year FE & No & No & Yes \\
\hline
\end{tabular}


Table 3. [Continued]

\begin{tabular}{|c|c|c|c|c|c|c|}
\hline \multicolumn{7}{|l|}{ Panel B. By Private Firm F/S Type } \\
\hline & & & Log. $I$ & Equity & & \\
\hline & (1) & (2) & (3) & (4) & (5) & (6) \\
\hline Transp. \% BS Items (private) & $\begin{array}{c}-0.607 * * * \\
(-4.42)\end{array}$ & $\begin{array}{c}-0.548 * * * \\
(-4.08)\end{array}$ & & & & \\
\hline Transp. \% PL Items (private) & & & $\begin{array}{c}-1.138 * * * \\
(-3.21)\end{array}$ & $\begin{array}{c}-1.001 * * * \\
(-2.90)\end{array}$ & & \\
\hline Transp. \% Footnote Items (private) & & & & & $\begin{array}{c}-4.583 * * * \\
(-4.86)\end{array}$ & $\begin{array}{c}-4.028 * * * \\
(-4.32)\end{array}$ \\
\hline Transp. \% FS Items (public) & $\begin{array}{c}0.759 * * * \\
(3.98)\end{array}$ & $\begin{array}{c}0.603 * * * \\
(3.21)\end{array}$ & $\begin{array}{c}0.658 * * * \\
(3.48)\end{array}$ & $\begin{array}{c}0.513 * * * \\
(2.74)\end{array}$ & $\begin{array}{c}0.598 * * * \\
(3.13)\end{array}$ & $\begin{array}{c}0.481 * * \\
(2.55)\end{array}$ \\
\hline Log. No. Public Firms & $\begin{array}{c}0.154 * * * \\
(4.08)\end{array}$ & $\begin{array}{c}0.081^{*} \\
(1.87)\end{array}$ & $\begin{array}{c}0.150 * * * \\
(3.92)\end{array}$ & $\begin{array}{c}0.075^{*} \\
(1.72)\end{array}$ & $\begin{array}{c}0.129 * * * \\
(3.25)\end{array}$ & $\begin{array}{l}0.068 \\
(1.54)\end{array}$ \\
\hline Log. No. Private Firms & $\begin{array}{c}-0.041 * * * \\
(-2.80)\end{array}$ & $\begin{array}{c}-0.051 * * * \\
(-3.52)\end{array}$ & $\begin{array}{c}-0.028 * * \\
(-1.99)\end{array}$ & $\begin{array}{c}-0.039 * * * \\
(-2.75)\end{array}$ & $\begin{array}{c}-0.028 * * \\
(-2.22)\end{array}$ & $\begin{array}{c}-0.038 * * * \\
(-3.00)\end{array}$ \\
\hline Log. Median Size (Total Assets) & $\begin{array}{l}-0.006 \\
(-0.42)\end{array}$ & $\begin{array}{l}0.004 \\
(0.24)\end{array}$ & $\begin{array}{l}0.001 \\
(0.03)\end{array}$ & $\begin{array}{l}0.011 \\
(0.69)\end{array}$ & $\begin{array}{l}0.006 \\
(0.40)\end{array}$ & $\begin{array}{l}0.016 \\
(1.04)\end{array}$ \\
\hline$R O A$ & $\begin{array}{c}2.046^{* * * *} \\
(5.24)\end{array}$ & $\begin{array}{c}1.996 * * * \\
(5.21)\end{array}$ & $\begin{array}{c}2.019 * * * \\
(5.19)\end{array}$ & $\begin{array}{c}1.989 * * * \\
(5.19)\end{array}$ & $\begin{array}{c}1.989 * * * \\
(5.14)\end{array}$ & $\begin{array}{c}1.941 * * * \\
(5.11)\end{array}$ \\
\hline Revenue Growth & $\begin{array}{l}-0.021 \\
(-0.66)\end{array}$ & $\begin{array}{c}0.055^{*} \\
(1.67)\end{array}$ & $\begin{array}{l}-0.019 \\
(-0.57)\end{array}$ & $\begin{array}{c}0.058 * \\
(1.78)\end{array}$ & $\begin{array}{l}-0.015 \\
(-0.48)\end{array}$ & $\begin{array}{c}0.058 * \\
(1.77)\end{array}$ \\
\hline Log. Country GDP & $\begin{array}{c}0.527 * * * \\
(7.02)\end{array}$ & $\begin{array}{c}0.660 * * * \\
(7.88)\end{array}$ & $\begin{array}{c}0.501 * * * \\
(6.75)\end{array}$ & $\begin{array}{c}0.643 * * * \\
(7.72)\end{array}$ & $\begin{array}{c}0.500 * * * \\
(6.75)\end{array}$ & $\begin{array}{c}0.651 * * * \\
(7.82)\end{array}$ \\
\hline Log. Population & $\begin{array}{c}-0.665^{*} \\
(-1.87)\end{array}$ & $\begin{array}{c}-1.552 * * * \\
(-4.10)\end{array}$ & $\begin{array}{c}-0.673^{*} \\
(-1.89)\end{array}$ & $\begin{array}{c}-1.590 * * * \\
(-4.20)\end{array}$ & $\begin{array}{l}-0.463 \\
(-1.28)\end{array}$ & $\begin{array}{c}-1.265 * * * \\
(-3.25)\end{array}$ \\
\hline FDI (\% of GDP) & $\begin{array}{l}0.000 \\
(0.70)\end{array}$ & $\begin{array}{c}0.000^{*} \\
(1.87)\end{array}$ & $\begin{array}{l}0.000 \\
(0.69)\end{array}$ & $\begin{array}{l}0.000 * \\
(1.89)\end{array}$ & $\begin{array}{l}0.000 \\
(1.05)\end{array}$ & $\begin{array}{c}0.000 * * \\
(2.14)\end{array}$ \\
\hline Obs. & 73,423 & 73,423 & 73,423 & 73,423 & 73,423 & 73,423 \\
\hline Adj. R2 & 0.871 & 0.873 & 0.871 & 0.873 & 0.871 & 0.874 \\
\hline Investor-Investee-Industry FE & Yes & Yes & Yes & Yes & Yes & Yes \\
\hline Year FE & No & Yes & No & Yes & No & Yes \\
\hline
\end{tabular}

Notes: This table presents the results from regressing foreign portfolio investment in public equity on private firm transparency. The dependent variable Log. FPI Equity is log of one plus the portfolio investment in public equity of an investee-industry-year held by foreign investors. In Panel A, Transp. \% FS Items (private) is the number of non-missing financial statement line items disclosed by private firms, divided by the total number of line items that these private firms can hypothetically disclose conditional on each private firm preparing and publishing financial statements (as proxied by the observability of at least one financial statement item). All columns include investor-investee-industry fixed effects, Columns (2) and (4) also include year fixed effects. In Panel B, Transp. \% FS Items (private) is dissected into the categories balance sheet (Columns (1) and (2)), profit and loss statement (Columns (3) and (4)), and Footnotes (Columns (5) and (6)). All columns include investor-investee-industry fixed effects, and the even-numbered columns also include year fixed effects. The unit of observation is at the investor-investee-industry-year level. The t-statistics reported in parentheses are based on standard errors clustered by investeeindustry-year. $* * *, * *, *$ indicates statistical significance at 1\%,5\%, and 10\%, respectively (two-tailed). Detailed definitions of all variables are in Appendix B. 
Table 4. Validating the Reallocation Mechanism:

Evidence from Bilateral Capital Constraints and Investor-Investee Distances

\begin{tabular}{|c|c|c|c|c|}
\hline \multirow[b]{3}{*}{ Friction Proxy: } & \multicolumn{4}{|c|}{ Log. FPI Equity } \\
\hline & \multicolumn{2}{|c|}{ Capital Constraints } & \multicolumn{2}{|c|}{ Distance } \\
\hline & $\begin{array}{c}\text { Capital } \\
\text { Control } \\
(1)\end{array}$ & $\begin{array}{c}\text { Currency } \\
\text { Appreciation } \\
\text { (2) }\end{array}$ & $\begin{array}{c}\text { Language } \\
\text { Distance } \\
\text { (3) }\end{array}$ & $\begin{array}{c}\text { Physical } \\
\text { Distance } \\
\text { (4) }\end{array}$ \\
\hline Transp. \% FS Items (private) * Friction & $\begin{array}{c}-0.258 * * * \\
(-3.09)\end{array}$ & $\begin{array}{c}-0.324 * * * \\
(-3.33)\end{array}$ & $\begin{array}{c}-0.363 * * * \\
(-2.59)\end{array}$ & $\begin{array}{c}-0.223 * * \\
(-2.10)\end{array}$ \\
\hline Transp. \% FS Items (private) & $\begin{array}{c}-0.367 * * * \\
(-4.00)\end{array}$ & $\begin{array}{c}-0.356 * * * \\
(-3.87)\end{array}$ & $\begin{array}{c}-0.363 * * * \\
(-3.90)\end{array}$ & $\begin{array}{c}-0.379 * * * \\
(-4.08)\end{array}$ \\
\hline Transp. \% FS Items (public) & $\begin{array}{c}0.613 * * * \\
(3.24)\end{array}$ & $\begin{array}{c}0.576 * * * \\
(3.07)\end{array}$ & $\begin{array}{c}0.529 * * * \\
(2.81)\end{array}$ & $\begin{array}{c}0.597 * * * \\
(3.14)\end{array}$ \\
\hline Log. No. Public Firms & $\begin{array}{c}0.079 * \\
(1.80)\end{array}$ & $\begin{array}{l}0.070 \\
(1.60)\end{array}$ & $\begin{array}{c}0.078^{*} \\
(1.76)\end{array}$ & $\begin{array}{c}0.078 * \\
(1.78)\end{array}$ \\
\hline Log. No. Private Firms & $\begin{array}{c}-0.052 * * * \\
(-3.56)\end{array}$ & $\begin{array}{c}-0.050 * * * \\
(-3.37)\end{array}$ & $\begin{array}{c}-0.054 * * * \\
(-3.67)\end{array}$ & $\begin{array}{c}-0.050 * * * \\
(-3.47)\end{array}$ \\
\hline Log. Median Size (Total Assets) & $\begin{array}{l}0.007 \\
(0.48)\end{array}$ & $\begin{array}{l}0.006 \\
(0.40)\end{array}$ & $\begin{array}{l}0.008 \\
(0.49)\end{array}$ & $\begin{array}{l}0.006 \\
(0.39)\end{array}$ \\
\hline$R O A$ & $\begin{array}{c}1.971 * * * \\
(5.09)\end{array}$ & $\begin{array}{c}2.015^{* * * *} \\
\quad(5.26)\end{array}$ & $\begin{array}{c}1.959 * * * \\
(5.10)\end{array}$ & $\begin{array}{c}2.115^{* * * *} \\
(5.42)\end{array}$ \\
\hline Revenue Growth & $\begin{array}{l}0.046 \\
(1.38)\end{array}$ & $\begin{array}{c}0.067 * * \\
(1.98)\end{array}$ & $\begin{array}{c}0.059^{*} \\
(1.78)\end{array}$ & $\begin{array}{c}0.077 * * \\
(2.31)\end{array}$ \\
\hline Log. Country GDP & $\begin{array}{c}0.667 * * * \\
(7.98)\end{array}$ & $\begin{array}{c}0.656 * * * \\
(7.83)\end{array}$ & $\begin{array}{c}0.679 * * * \\
(8.05)\end{array}$ & $\begin{array}{c}0.660 * * * \\
(7.84)\end{array}$ \\
\hline Log. Population & $\begin{array}{c}-1.550 * * * \\
(-4.04)\end{array}$ & $\begin{array}{c}-1.486^{* * *} \\
(-3.91)\end{array}$ & $\begin{array}{c}-1.600 * * * \\
(-4.14)\end{array}$ & $\begin{array}{c}-1.480 * * * \\
(-3.83)\end{array}$ \\
\hline$F D I(\%$ of $G D P)$ & $\begin{array}{l}0.000 \\
(1.09) \\
\end{array}$ & $\begin{array}{c}0.000 * * \\
(2.21)\end{array}$ & $\begin{array}{c}0.000^{*} \\
(1.86)\end{array}$ & $\begin{array}{c}0.000 * \\
(1.85) \\
\end{array}$ \\
\hline Obs. & 73,423 & 73,423 & 73,423 & 73,423 \\
\hline Adj. R2 & 0.874 & 0.874 & 0.874 & 0.874 \\
\hline Investor-Investee-Industry FE & Yes & Yes & Yes & Yes \\
\hline Year FE & Yes & Yes & Yes & Yes \\
\hline Controls*Friction & Yes & Yes & Yes & Yes \\
\hline Year FE*Friction & Yes & Yes & Yes & Yes \\
\hline
\end{tabular}

Notes: This table presents the results from regressing foreign portfolio investment in public equity on private firm transparency, conditional on investors facing capital controls when investing in a given investee country. The dependent variable Log. FPI Equity is the natural logarithm of one plus the portfolio investment stock in public equity of an investee country-industry held by foreign investors each year. The independent variable of interest Transp. \% FS Items (private) is defined as the number of non-missing financial statement line items disclosed by private firms, divided by the total number of line items that these private firms can hypothetically disclose conditional on each private firm preparing and publishing financial statements (as proxied by the observability of at least one financial statement item). Capital Control is an indicator variable equal to lif the product of investor country's capital control index and investee country's capital control index - as developed by Fernández et al. (2016) - is in the top decile within each investee subsample, and 0, otherwise. Currency Appreciation is an indicator variable equal to 1 if the percentage increase of the investee country's annual real effective exchange rate is in the top decile within each investee subsample, and 0, otherwise. Language Distance is an indicator variable equal to 1 if the language distance index is in the top decile within each investee subsample, and 0, otherwise. Physical Distance is an indicator variable equal to 1 if the physical distance index is in the top decile within each investee subsample, and 0, otherwise. All columns include investor-investee-industry and year fixed effects. The cross-sectional friction proxies are interacted with all control variables and year fixed effects. The unit of observation is at the investor-investee-industry-year level. The t-statistics reported below the coefficient estimates in parentheses are computed based on standard errors clustered by investee-industry-year. $* * *, * * *, *$ indicates statistical significance at $1 \%, 5 \%$, and $10 \%$, respectively (two-tailed). Detailed definitions of all variables are in Appendix B. 
Table 5. Validating the Reallocation Mechanism: Evidence from Capital Allocation to Private Firms

\begin{tabular}{|c|c|c|c|c|c|c|}
\hline \multicolumn{7}{|c|}{ Panel A. Mergers and Acquisitions Investments } \\
\hline & \multicolumn{3}{|c|}{ Private Firm Acquisitions } & \multicolumn{3}{|c|}{ Public Firm Acquisitions } \\
\hline & $\begin{array}{c}\text { Log. Number of } \\
\text { M\&A Deals } \\
\text { (private) } \\
\text { (1) }\end{array}$ & $\begin{array}{c}\text { Log. M\&A } \\
\text { Deal Value } \\
\text { (private) } \\
\text { (2) }\end{array}$ & $\begin{array}{c}\text { Log. } M \& A \\
\text { Revenue } \\
\text { (private) } \\
\text { (3) } \\
\end{array}$ & $\begin{array}{c}\text { Log. Number of } \\
\text { M\&A Deals } \\
\text { (public) } \\
(4)\end{array}$ & $\begin{array}{c}\text { Log. M\&A } \\
\text { Deal Value } \\
\text { (public) } \\
(5)\end{array}$ & $\begin{array}{c}\text { Log. M\&A } \\
\text { Revenue } \\
\text { (public) } \\
(6) \\
\end{array}$ \\
\hline Transp. \% FS Items (private) & $\begin{array}{c}0.044 * * * \\
(4.72)\end{array}$ & $\begin{array}{c}0.335 * * * \\
(3.30)\end{array}$ & $\begin{array}{c}0.277 * * \\
(2.57)\end{array}$ & $\begin{array}{c}-0.003 * * \\
(-2.22)\end{array}$ & $\begin{array}{c}-0.070 * * \\
(-2.03)\end{array}$ & $\begin{array}{c}-0.063^{*} \\
(-1.94)\end{array}$ \\
\hline Transp. \% FS Items (public) & $\begin{array}{c}-0.048 * * \\
(-2.09)\end{array}$ & $\begin{array}{l}-0.270 \\
(-1.12)\end{array}$ & $\begin{array}{l}-0.050 \\
(-0.21)\end{array}$ & $\begin{array}{l}0.002 \\
(0.61)\end{array}$ & $\begin{array}{l}0.040 \\
(0.66)\end{array}$ & $\begin{array}{l}0.027 \\
(0.44)\end{array}$ \\
\hline Log. No. Public Firms & $\begin{array}{l}-0.002 \\
(-0.69)\end{array}$ & $\begin{array}{l}0.012 \\
(0.32)\end{array}$ & $\begin{array}{l}0.043 \\
(1.03)\end{array}$ & $\begin{array}{l}0.001 \\
(1.07)\end{array}$ & $\begin{array}{l}0.010 \\
(0.84)\end{array}$ & $\begin{array}{l}0.009 \\
(0.84)\end{array}$ \\
\hline Log. No. Private Firms & $\begin{array}{c}0.006 * * * \\
(3.62)\end{array}$ & $\begin{array}{c}0.056 * * * \\
(3.17)\end{array}$ & $\begin{array}{c}0.053 * * * \\
(2.90)\end{array}$ & $\begin{array}{l}-0.000 \\
(-0.12)\end{array}$ & $\begin{array}{l}0.000 \\
(0.09)\end{array}$ & $\begin{array}{l}0.000 \\
(0.07)\end{array}$ \\
\hline Log. Median Size (Total Assets) & $\begin{array}{c}0.007 * * * \\
(4.90)\end{array}$ & $\begin{array}{c}0.057 * * * \\
(4.07)\end{array}$ & $\begin{array}{c}0.061 * * * \\
(3.99)\end{array}$ & $\begin{array}{l}0.000 \\
(1.15)\end{array}$ & $\begin{array}{l}0.004 \\
(0.97)\end{array}$ & $\begin{array}{l}0.004 \\
(0.94)\end{array}$ \\
\hline$R O A$ & $\begin{array}{c}0.069 * * \\
(2.43)\end{array}$ & $\begin{array}{l}0.324 \\
(1.05)\end{array}$ & $\begin{array}{l}0.507 \\
(1.45)\end{array}$ & $\begin{array}{l}0.002 \\
(0.71)\end{array}$ & $\begin{array}{l}0.019 \\
(0.22)\end{array}$ & $\begin{array}{l}0.065 \\
(0.84)\end{array}$ \\
\hline Revenue Growth & $\begin{array}{l}0.003 \\
(1.35)\end{array}$ & $\begin{array}{l}0.032 \\
(1.14)\end{array}$ & $\begin{array}{l}0.051 \\
(1.64)\end{array}$ & $\begin{array}{l}-0.000 \\
(-0.80)\end{array}$ & $\begin{array}{l}-0.003 \\
(-0.32)\end{array}$ & $\begin{array}{l}-0.003 \\
(-0.41)\end{array}$ \\
\hline Log. Country GDP & $\begin{array}{l}0.002 \\
(0.23)\end{array}$ & $\begin{array}{c}0.167 * * \\
(2.27)\end{array}$ & $\begin{array}{l}-0.013 \\
(-0.15)\end{array}$ & $\begin{array}{l}-0.001 \\
(-1.17)\end{array}$ & $\begin{array}{c}-0.037 * \\
(-1.66)\end{array}$ & $\begin{array}{l}-0.019 \\
(-0.98)\end{array}$ \\
\hline Log. Population & $\begin{array}{l}0.033 \\
(0.88)\end{array}$ & $\begin{array}{c}0.891 * * \\
(2.24)\end{array}$ & $\begin{array}{l}0.495 \\
(1.06)\end{array}$ & $\begin{array}{l}-0.001 \\
(-0.20)\end{array}$ & $\begin{array}{l}-0.039 \\
(-0.23)\end{array}$ & $\begin{array}{l}-0.107 \\
(-0.72)\end{array}$ \\
\hline$F D I(\%$ of $G D P)$ & $\begin{array}{c}-0.000 * * * \\
(-5.61)\end{array}$ & $\begin{array}{c}-0.000 * * * \\
(-5.43)\end{array}$ & $\begin{array}{c}-0.000 * * * \\
(-4.71)\end{array}$ & $\begin{array}{l}-0.000 \\
(-1.23)\end{array}$ & $\begin{array}{l}-0.000 \\
(-1.03)\end{array}$ & $\begin{array}{l}-0.000 \\
(-1.01)\end{array}$ \\
\hline Obs. & 73,423 & 73,423 & 73,423 & 73,423 & 73,423 & 73,423 \\
\hline Adj. R2 & 0.694 & 0.454 & 0.518 & 0.141 & 0.097 & 0.098 \\
\hline Investor-Investee-Industry FE & Yes & Yes & Yes & Yes & Yes & Yes \\
\hline Year FE & Yes & Yes & Yes & Yes & Yes & Yes \\
\hline
\end{tabular}


Table 5. [Continued]

\begin{tabular}{|c|c|c|c|}
\hline & $\begin{array}{c}\text { Log. Number of VC Deals } \\
\text { (1) }\end{array}$ & $\begin{array}{l}\text { Log. VC Deal Value } \\
\text { (2) }\end{array}$ & $\begin{array}{l}\text { Log. VC Revenue } \\
\text { (3) }\end{array}$ \\
\hline Transp. \% FS Items (private) & $\begin{array}{l}0.015 * * * \\
(3.83)\end{array}$ & $\begin{array}{c}0.180 * * * \\
(3.79)\end{array}$ & $\begin{array}{l}0.104 * * * \\
(2.61)\end{array}$ \\
\hline Transp. \% FS Items (public) & $\begin{array}{l}-0.013 \\
(-1.11)\end{array}$ & $\begin{array}{l}-0.141 \\
(-1.14)\end{array}$ & $\begin{array}{r}-0.183^{*} \\
(-1.87)\end{array}$ \\
\hline Log. No. Public Firms & $\begin{array}{c}0.007 * * * \\
(4.34)\end{array}$ & $\begin{array}{c}0.046 * * * \\
(2.75)\end{array}$ & $\begin{array}{c}0.066 * * * \\
(4.59)\end{array}$ \\
\hline Log. No. Private Firms & $\begin{array}{c}0.002 * * \\
(2.41)\end{array}$ & $\begin{array}{c}0.027 * * * \\
(3.09)\end{array}$ & $\begin{array}{c}0.017 * * \\
(2.31)\end{array}$ \\
\hline Log. Median Size (Total Assets) & $\begin{array}{c}0.002 * * * \\
(3.13)\end{array}$ & $\begin{array}{c}0.025 * * * \\
(3.21)\end{array}$ & $\begin{array}{l}0.008 \\
(1.26)\end{array}$ \\
\hline$R O A$ & $\begin{array}{c}0.040 * * * \\
(2.84)\end{array}$ & $\begin{array}{c}0.401 * * * \\
(2.77)\end{array}$ & $\begin{array}{c}0.221^{* *} \\
(1.99)\end{array}$ \\
\hline Revenue Growth & $\begin{array}{l}0.001 \\
(1.36)\end{array}$ & $\begin{array}{l}0.012 \\
(1.02)\end{array}$ & $\begin{array}{l}-0.004 \\
(-0.41)\end{array}$ \\
\hline Log. Country GDP & $\begin{array}{c}0.020 * * * \\
(5.01)\end{array}$ & $\begin{array}{c}0.218 * * * \\
(5.63)\end{array}$ & $\begin{array}{c}0.162 * * * \\
(5.00)\end{array}$ \\
\hline Log. Population & $\begin{array}{c}-0.055^{* * *} \\
(-3.75)\end{array}$ & $\begin{array}{c}-0.732 * * * \\
(-4.38)\end{array}$ & $\begin{array}{c}-0.571 * * * \\
(-4.27)\end{array}$ \\
\hline$F D I(\%$ of $G D P)$ & $\begin{array}{r}-0.000^{*} \\
(-1.86)\end{array}$ & $\begin{array}{l}-0.000 \\
(-0.36)\end{array}$ & $\begin{array}{l}-0.000 \\
(-0.46)\end{array}$ \\
\hline Obs. & 73,423 & 73,423 & 73,423 \\
\hline Adj. R2 & 0.464 & 0.324 & 0.276 \\
\hline Investor-Investee-Industry FE & Yes & Yes & Yes \\
\hline Year FE & Yes & Yes & Yes \\
\hline
\end{tabular}

Notes: This table presents the results from regressing foreign investment in private firm equity on private firm transparency. In Panel A, the dependent variables proxy for direct investments by foreign investors through M\&A deals that involve target firms in the investee-industry. In columns (1) to (3), the variables are measured using private target firms only. In columns (4) to (6), the variables are measured using public target firms only. Log. Number of M\&A Deals is the natural logarithm of the number of acquired target firms of the deals with official deal completion dates within the two following years. Log. M\&A Deal Value is the natural logarithm of the total transaction value (set to 0 if undisclosed) of deals with official deal completion dates within the two following years. $\log . M \& A$ Revenue is the natural logarithm of the sum of revenues of target firms. In Panel B, dependent variables are constructed analogously for venture capital transactions that involve deals with foreign investors and private target firms of the deals with official deal completion dates within the two following years. The independent variable of interest Transp. \% FS Items (private) is defined as the number of non-missing financial statement line items disclosed by private firms, divided by the total number of line items that these private firms can hypothetically disclose conditional on each private firm preparing and publishing financial statements (as proxied by the observability of at least one financial statement item). All columns include investorinvestee-industry and year fixed effects. The unit of observation is at the investor-investee-industry-year level. The t-statistics reported below the coefficient estimates in parentheses are computed based on standard errors clustered by investee-industry-year. $* * *, * * *, *$ indicates statistical significance at $1 \%, 5 \%$, and $10 \%$, respectively (two-tailed). Detailed definitions of all variables are provided in Appendix B. 
Table 6. Who Benefits from Private Firm Disclosures? A Firm Level Analysis

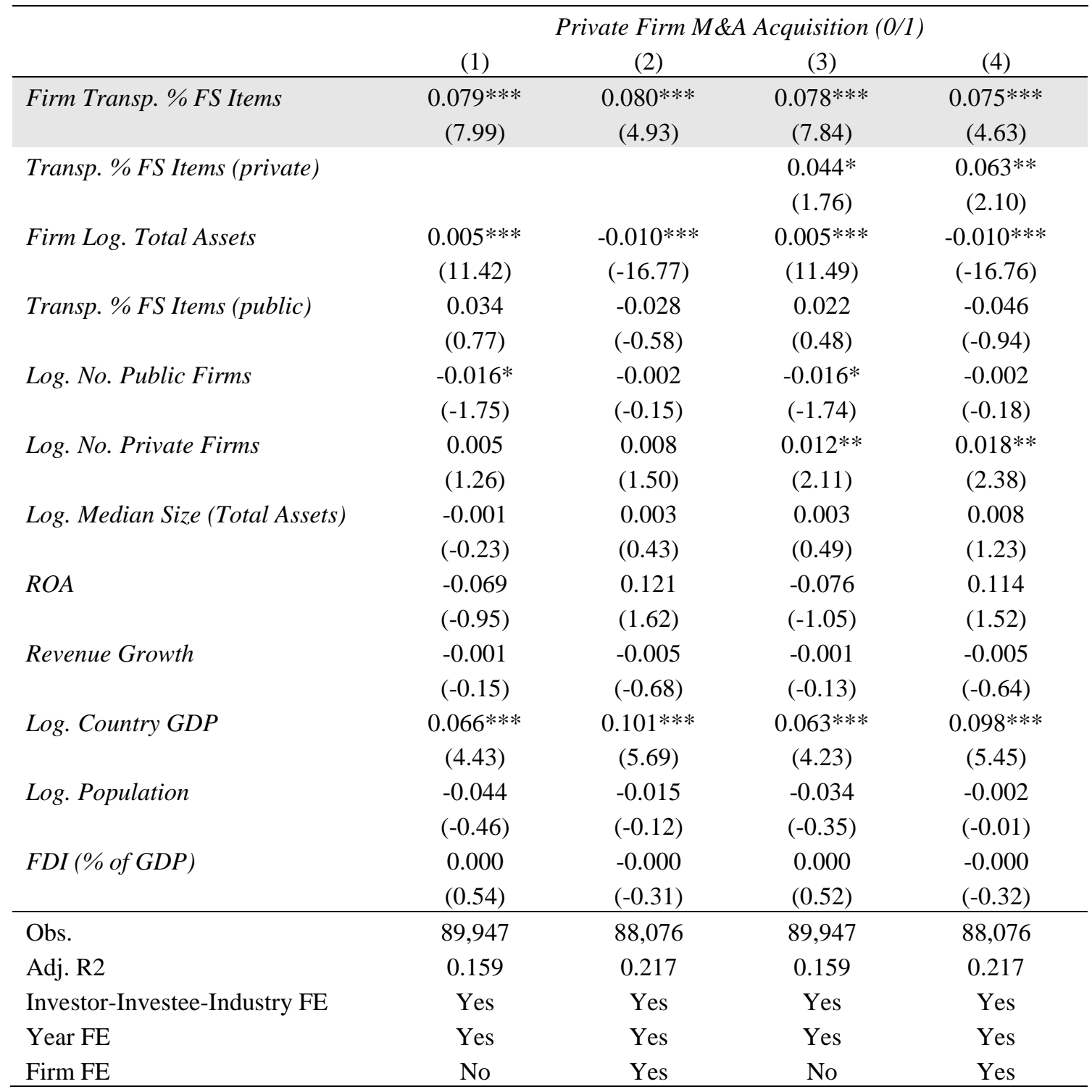

Notes: This table presents the results from regressing foreign M\&A investment in private firm equity on private firm transparency. The unit of observation is the individual target firm-year. The sample consists of all private firms that get acquired through an M\&A deal in our investee countries in the period 2005-2017 and that are observable in the Orbis database. The dependent variable Private Firm M\&A Acquisition (0/1) is an indicator taking on the value of 1 in the year a private firm is acquired by a foreign investor. Target firm-year observations are removed after the M\&A deal. Thus, the regression estimates the incremental likelihood of a private firm being acquired by a foreign investor through an $M \& A$ deal in a given year. The independent variable of interest Firm Transp. \% FS Items (private) is defined as the number of non-missing financial statement line items disclosed by an individual private target firm in a given year, divided by the 39 line items that the firm can hypothetically disclose. Transp. \% FS Items (private) is defined as in the previous tests (the number of non-missing financial statement line items disclosed by private firms, divided by the total number of line items that these private firms can hypothetically disclose conditional on each private firm preparing and publishing financial statements (as proxied by the observability of at least one financial statement item)). All columns include investor-investee-industry and year fixed effects. Columns (2) and (4) also include individual firm fixed effects. The tstatistics reported below the coefficient estimates in parentheses are computed based on standard errors clustered by investeeindustry-year. $* * *, * * * *$ indicates statistical significance at $1 \%, 5 \%$, and $10 \%$, respectively (two-tailed). Definitions of all variables are in Appendix B. 
Table 7. Difference-in-Differences Tests

Staggered BvD Global Office Openings and Business Register Implementations in Investee Countries

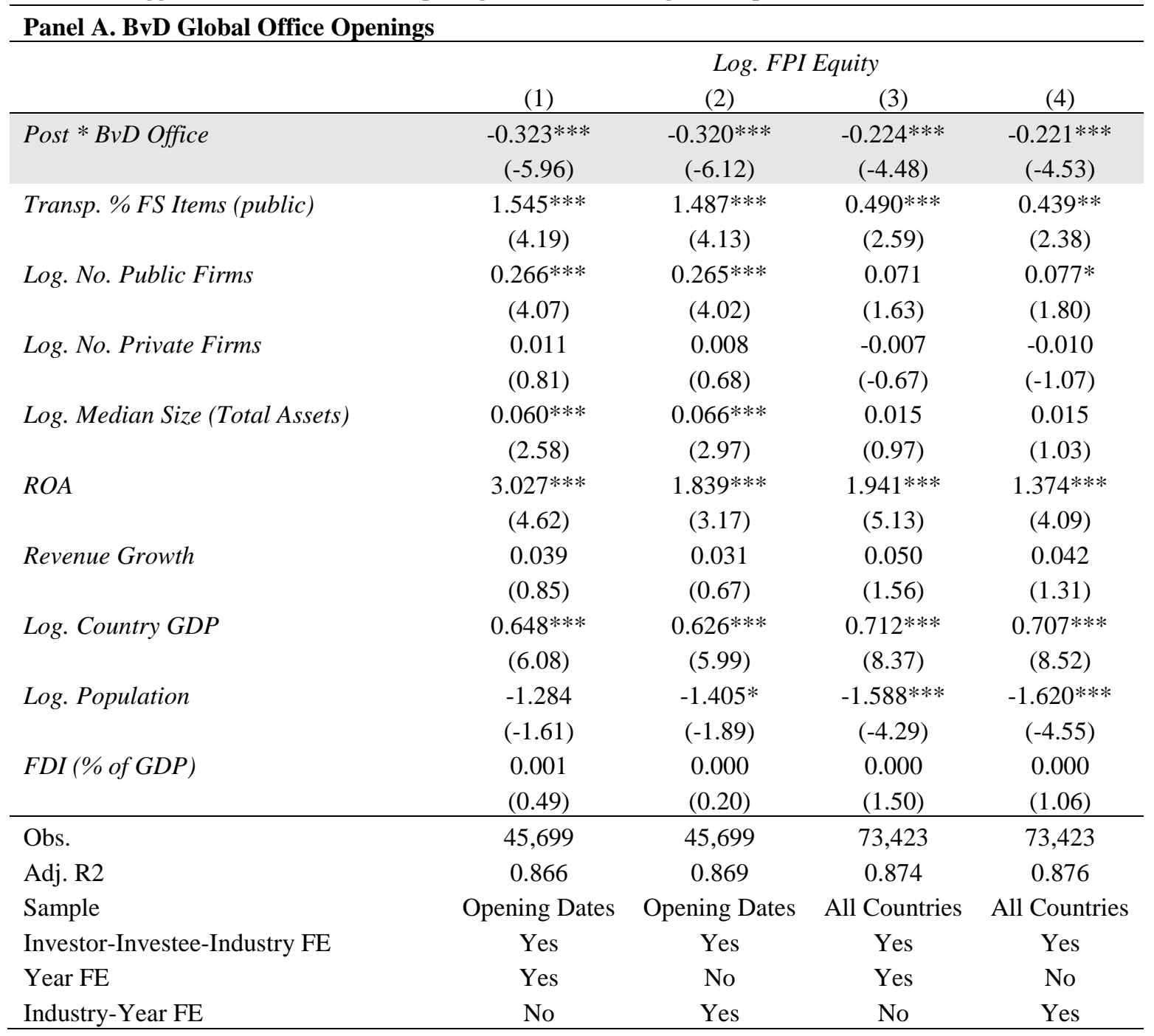


Table 7. [Continued]

\begin{tabular}{|c|c|c|c|c|}
\hline \multicolumn{5}{|c|}{ Panel B. Business Register Implementations in Europe } \\
\hline & \multicolumn{4}{|c|}{ Log. FPI Equity } \\
\hline & (1) & (2) & (3) & (4) \\
\hline Post * Business Register & $\begin{array}{c}-0.152 * * * \\
(-3.32)\end{array}$ & $\begin{array}{c}-0.156 * * * \\
(-3.58)\end{array}$ & $\begin{array}{c}-0.137 * * * \\
(-3.06)\end{array}$ & $\begin{array}{c}-0.141 * * * \\
(-3.34)\end{array}$ \\
\hline Transp. \% FS Items (public) & $\begin{array}{c}0.675 * * * \\
(2.77)\end{array}$ & $\begin{array}{c}0.671 * * * \\
(2.74)\end{array}$ & $\begin{array}{c}0.732^{* * * *} \\
(3.19)\end{array}$ & $\begin{array}{c}0.675^{* * * *} \\
(2.91)\end{array}$ \\
\hline Log. No. Public Firms & $\begin{array}{l}-0.096 * \\
(-1.74)\end{array}$ & $\begin{array}{c}-0.127 * * \\
(-2.48)\end{array}$ & $\begin{array}{l}-0.046 \\
(-0.90)\end{array}$ & $\begin{array}{l}-0.060 \\
(-1.27)\end{array}$ \\
\hline Log. No. Private Firms & $\begin{array}{c}-0.105 * * * \\
(-3.90)\end{array}$ & $\begin{array}{c}-0.099 * * * \\
(-3.97)\end{array}$ & $\begin{array}{c}-0.078 * * * \\
(-3.32)\end{array}$ & $\begin{array}{c}-0.071 * * * \\
(-3.21)\end{array}$ \\
\hline Log. Median Size (Total Assets) & $\begin{array}{c}-0.066 * * \\
(-1.96)\end{array}$ & $\begin{array}{c}-0.068 * * \\
(-2.29)\end{array}$ & $\begin{array}{l}-0.016 \\
(-0.60)\end{array}$ & $\begin{array}{l}-0.018 \\
(-0.75)\end{array}$ \\
\hline$R O A$ & $\begin{array}{c}1.299 * * \\
(2.31)\end{array}$ & $\begin{array}{c}0.954 * \\
(1.93)\end{array}$ & $\begin{array}{c}1.405 * * * \\
(2.88)\end{array}$ & $\begin{array}{c}1.173 * * * \\
(2.71)\end{array}$ \\
\hline Revenue Growth & $\begin{array}{l}-0.042 \\
(-0.85)\end{array}$ & $\begin{array}{l}-0.027 \\
(-0.59)\end{array}$ & $\begin{array}{l}-0.015 \\
(-0.36)\end{array}$ & $\begin{array}{l}-0.003 \\
(-0.08)\end{array}$ \\
\hline Log. Country GDP & $\begin{array}{c}1.189 * * * \\
(7.71)\end{array}$ & $\begin{array}{c}1.200 * * * \\
(8.55)\end{array}$ & $\begin{array}{c}1.091 * * * \\
(7.74)\end{array}$ & $\begin{array}{c}1.088^{* * * *} \\
(8.48)\end{array}$ \\
\hline Log. Population & $\begin{array}{c}-1.018 * \\
(-1.75)\end{array}$ & $\begin{array}{l}-1.041^{*} \\
(-1.88)\end{array}$ & $\begin{array}{c}-1.160 * * \\
(-2.17)\end{array}$ & $\begin{array}{c}-1.249 * * \\
(-2.46)\end{array}$ \\
\hline$F D I(\%$ of $G D P)$ & $\begin{array}{l}0.001 \\
(1.02) \\
\end{array}$ & $\begin{array}{l}0.001 \\
(0.90) \\
\end{array}$ & $\begin{array}{c}0.001 * * \\
(2.57)\end{array}$ & $\begin{array}{c}0.001 * * \\
(2.51)\end{array}$ \\
\hline Obs. & 36,576 & 36,576 & 41,470 & 41,470 \\
\hline Adj. R2 & 0.882 & 0.885 & 0.879 & 0.882 \\
\hline Sample & Registered & Registered & All Europe & All Europe \\
\hline Investor-Investee-Industry FE & Yes & Yes & Yes & Yes \\
\hline Year FE & Yes & No & Yes & No \\
\hline Industry-Year FE & No & Yes & No & Yes \\
\hline
\end{tabular}

Notes: This table presents the results from regressing foreign investment in private firm equity on dummy variables indicating the opening of a BvD office in the investee country or the implementation of electronic business registers. In Panel A, Post $*$ BvD Office is a dummy variable equal to one if a BvD office exists (i.e., has been opened) in a given investee country in a given year. In Panel B, Post * Business Register is a dummy variable equal to one for years after the electronic business register starts to operate in a given investee country in a given year. The dependent variable Log. FPI Equity is log of one plus the portfolio investment stock in public equity of an investee country-industry held by foreign investors each year. In Columns (1) and (2) in Panel A, the sample is restricted to observations in investee-countries for which $\mathrm{BvD}$ office opening dates are available. In Columns (1) and (2) in Panel B, the sample is restricted to observations in investee-countries in which business registers start to operate at some point in time. Columns (3) and (4) use the full sample. All columns include investor-investee-industry fixed effects. Columns (1) and (3) include year fixed effects. Columns (2) and (4) include industry-year fixed effects. The unit of observation is at the investorinvestee-industry-year level. The t-statistics reported below the coefficient estimates in parentheses are computed based on standard errors clustered by investee-industry-year. ***, ***, * indicates statistical significance at 1\%, 5\%, and 10\%, respectively (twotailed). Detailed definitions of all variables are in Appendix B. 


\section{Table 8. Robustness Tests}

\begin{tabular}{|c|c|c|c|c|c|}
\hline \multicolumn{6}{|l|}{ Panel A. Alternative Fixed Effects and Transparency Proxies } \\
\hline & (1) & (2) & (3) & (4) & (5) \\
\hline Transp. \% FS Items (private) & $\begin{array}{c}-0.444 * * * \\
(-4.86)\end{array}$ & & & & \\
\hline Transp. Log. Total FS Items (private) & & $\begin{array}{c}-0.190 * * * \\
(-5.53)\end{array}$ & & & \\
\hline Transp. Log. Total FS Items (private) / Industry GDP & & & $\begin{array}{c}-0.196 * * * \\
(-5.98)\end{array}$ & & \\
\hline Transp. \% FS Items (private, weighted) & & & & $\begin{array}{c}-0.382 * * * \\
(-4.37)\end{array}$ & \\
\hline Transp. Total FS Items Quintile & & & & & $\begin{array}{c}-0.311 * * \\
(-2.28)\end{array}$ \\
\hline Transp. \% FS Items (public) & $\begin{array}{c}0.549 * * * \\
(2.96)\end{array}$ & $\begin{array}{c}0.594 * * * \\
(3.15)\end{array}$ & $\begin{array}{c}0.605^{* * *} * \\
(3.19)\end{array}$ & $\begin{array}{c}0.764 * * * \\
(3.99)\end{array}$ & $\begin{array}{c}0.530 * * * \\
(2.84)\end{array}$ \\
\hline Log. No. Public Firms & $\begin{array}{c}0.088 * * \\
(2.01)\end{array}$ & $\begin{array}{c}0.101 * * \\
(2.34)\end{array}$ & $\begin{array}{l}-0.012 \\
(-0.25)\end{array}$ & $\begin{array}{c}0.076^{*} \\
(1.76)\end{array}$ & $\begin{array}{c}0.086 * * \\
(2.00)\end{array}$ \\
\hline Log. No. Private Firms & $\begin{array}{c}-0.064 * * * \\
(-4.52)\end{array}$ & $\begin{array}{c}0.095 * * * \\
(4.62)\end{array}$ & $\begin{array}{c}0.102 * * * \\
(4.97)\end{array}$ & $\begin{array}{c}-0.018 * \\
(-1.78)\end{array}$ & $\begin{array}{l}0.005 \\
(0.40)\end{array}$ \\
\hline Log. Median Size (Total Assets) & $\begin{array}{l}-0.003 \\
(-0.18)\end{array}$ & $\begin{array}{l}-0.010 \\
(-0.63)\end{array}$ & $\begin{array}{l}-0.015 \\
(-0.97)\end{array}$ & $\begin{array}{l}0.023 \\
(1.49)\end{array}$ & $\begin{array}{l}0.015 \\
(0.99)\end{array}$ \\
\hline$R O A$ & $\begin{array}{c}1.405^{* * *} \\
(4.13)\end{array}$ & $\begin{array}{c}1.996 * * * \\
(5.25)\end{array}$ & $\begin{array}{c}1.926 * * * \\
(5.10)\end{array}$ & $\begin{array}{c}1.977 * * * \\
(5.17)\end{array}$ & $\begin{array}{c}1.974 * * * \\
(5.16)\end{array}$ \\
\hline Revenue Growth & $\begin{array}{l}0.045 \\
(1.36)\end{array}$ & $\begin{array}{l}0.054 \\
(1.64)\end{array}$ & $\begin{array}{l}0.051 \\
(1.56)\end{array}$ & $\begin{array}{l}0.037 \\
(1.13)\end{array}$ & $\begin{array}{c}0.059 * \\
(1.82)\end{array}$ \\
\hline Log. Country GDP & $\begin{array}{c}0.639 * * * \\
(7.79)\end{array}$ & $\begin{array}{c}0.665^{* * *} * \\
(7.95)\end{array}$ & $\begin{array}{c}0.549 * * * \\
(6.64)\end{array}$ & $\begin{array}{c}0.632 * * * \\
(7.59)\end{array}$ & $\begin{array}{c}0.634 * * * \\
(7.63)\end{array}$ \\
\hline Log. Population & $\begin{array}{c}-1.611 * * * \\
(-4.35)\end{array}$ & $\begin{array}{c}-1.637 * * * \\
(-4.40)\end{array}$ & $\begin{array}{c}-1.536 * * * \\
(-4.10)\end{array}$ & $\begin{array}{c}-1.531 * * * \\
(-4.09)\end{array}$ & $\begin{array}{c}-1.748 * * * \\
(-4.76)\end{array}$ \\
\hline$F D I(\%$ of $G D P)$ & $\begin{array}{l}0.000 \\
(1.32)\end{array}$ & $\begin{array}{c}0.000 * * \\
(2.20)\end{array}$ & $\begin{array}{c}0.000 * * * \\
(2.65)\end{array}$ & $\begin{array}{l}0.000 \\
(1.59)\end{array}$ & $\begin{array}{c}0.000 * \\
(1.73)\end{array}$ \\
\hline Obs. & 73,423 & 73,423 & 73,423 & 73,423 & 73,423 \\
\hline Adj. R2 & 0.879 & 0.874 & 0.874 & 0.873 & 0.873 \\
\hline Investor-Investee-Industry FE & Yes & Yes & Yes & Yes & Yes \\
\hline Year FE & No & Yes & Yes & Yes & Yes \\
\hline Investor-Industry-Year FE & Yes & No & No & No & No \\
\hline
\end{tabular}


Table 8. [Continued]

\begin{tabular}{|c|c|c|c|}
\hline & $\begin{array}{c}\text { Log. FPI Equity } \\
\text { (Intensive Margin) } \\
\text { (1) }\end{array}$ & $\begin{array}{l}\text { Log. FPI Equity } \\
\text { (Tax Haven) } \\
(2)\end{array}$ & $\begin{array}{c}\text { Log. FPI Equity } \\
\text { (Residency) } \\
\text { (3) }\end{array}$ \\
\hline Transp. \% FS Items (private) & $\begin{array}{c}-0.647 * * * \\
(-5.42)\end{array}$ & $\begin{array}{c}-0.263 * * * \\
(-3.01)\end{array}$ & $\begin{array}{c}-0.354 * * * \\
(-3.74)\end{array}$ \\
\hline Transp. \% FS Items (public) & $\begin{array}{l}0.412 \\
(1.21)\end{array}$ & $\begin{array}{c}0.641 * * * \\
(3.38)\end{array}$ & $\begin{array}{c}0.969 * * * \\
(4.71)\end{array}$ \\
\hline Log. No. Public Firms & $\begin{array}{l}0.118^{*} \\
(1.91)\end{array}$ & $\begin{array}{l}0.066 \\
(1.54)\end{array}$ & $\begin{array}{l}-0.032 \\
(-0.78)\end{array}$ \\
\hline Log. No. Private Firms & $\begin{array}{c}-0.075 * * * \\
(-3.70)\end{array}$ & $\begin{array}{c}-0.039 * * * \\
(-2.75)\end{array}$ & $\begin{array}{c}-0.068 * * * \\
(-4.18)\end{array}$ \\
\hline Log. Median Size (Total Assets) & $\begin{array}{l}0.012 \\
(0.50)\end{array}$ & $\begin{array}{l}0.013 \\
(0.87)\end{array}$ & $\begin{array}{c}0.032 * * \\
(1.97)\end{array}$ \\
\hline$R O A$ & $\begin{array}{c}3.328 * * * \\
(6.34)\end{array}$ & $\begin{array}{c}1.948 * * * \\
(5.21)\end{array}$ & $\begin{array}{c}2.501 * * * \\
(6.61)\end{array}$ \\
\hline Revenue Growth & $\begin{array}{l}0.050 \\
(0.96)\end{array}$ & $\begin{array}{c}0.102 * * * \\
(3.08)\end{array}$ & $\begin{array}{c}0.108 * * * \\
(2.95)\end{array}$ \\
\hline Log. Country GDP & $\begin{array}{c}0.763 * * * \\
(6.96)\end{array}$ & $\begin{array}{c}0.689 * * * \\
(8.31)\end{array}$ & $\begin{array}{c}0.437 * * * \\
(4.85)\end{array}$ \\
\hline Log. Population & $\begin{array}{l}-0.297 \\
(-0.38)\end{array}$ & $\begin{array}{c}-1.463 * * * \\
(-3.80)\end{array}$ & $\begin{array}{c}1.683 * * * \\
(3.06)\end{array}$ \\
\hline$F D I(\%$ of $G D P)$ & $\begin{array}{l}0.000 \\
(0.58) \\
\end{array}$ & $\begin{array}{c}0.000 * * \\
(2.20) \\
\end{array}$ & $\begin{array}{l}-0.000 \\
(-0.16) \\
\end{array}$ \\
\hline Obs. & 34,314 & 73,423 & 73,423 \\
\hline Adj. R2 & 0.843 & 0.872 & 0.857 \\
\hline Investor-Investee-Industry FE & Yes & Yes & Yes \\
\hline Year FE & Yes & Yes & Yes \\
\hline Investee-Industry FE & No & No & No \\
\hline
\end{tabular}

Notes: This table presents the results from several robustness tests. In Panel A, foreign portfolio investment in public equity is regressed on private firm transparency using different model specifications and modified versions of the independent variable of interest (Transp. \% FS Items (private)) to assess the sensitivity of results to the measurement of private firm transparency. In Panel $\mathrm{B}$, we replicate the baseline analysis (column (2) of Table 3) using modified versions of the dependent variable of interest ( Log. FPI Equity). The unit of observation is at the investor-investee-industry-year level.. The t-statistics reported below the coefficient estimates in parentheses are computed based on standard errors clustered by investee-industry. ***, ***, * indicates statistical significance at 1\%,5\%, and 10\%, respectively (two-tailed). Detailed definitions of all variables are provided in Appendix B. 


\section{Appendices \\ How does Private Firm Disclosure Affect Demand for Public Firm Equity? \\ Evidence from the Global Equity Market}

\section{Appendix A. Measurement of Private Firm Transparency}

\section{Appendix B. Variables Definitions}

Appendix C. Appendix Figures and Tables

- Figure A1. Residual Variation of our Private Firm Transparency Measure for the US, the UK, and Germany

- Table A1. Sample Construction for Main Sample

- Table A2. Sample Construction for M\&A and VC Transactions

- Table A3. Staggered BvD Office Opening Years

- Table A4. Determinants of BvD Office Openings

- Table A5. Staggered Electronic Business Register Implementation Years 


\section{Appendix A. Measurement of Private Firm Transparency}

We define private firm financial reporting transparency based on the granularity of disclosed financial statement information following the intuition in Chen et al. (2015). BvD collects financial statement information on public and private firms from their publicly available disclosures which are predominantly available through domestic business registers (Kalemli-Özcan et al. (2019); Breuer (2021)). BvD then organizes the data in a standard financial statement format with consistent financial statement items labelled in English, following the most common financial reporting formats used in the European Union (Kalemli-Özcan et al. (2019); Pinto Ribeiro et al. (2010)) We rely on this standardized global financial statement format to measure the relative granularity of private firms' financial statements at the aggregate investee-industry-year level. Standardization is extremely useful in our context since it facilitates comparison of financial statement transparencies across investee countries that may have different formatting requirements of financial statement disclosures. There are 39 unique standardized financial statement items, 22 of which belong to the balance sheet, 10 of which belong to the income statement, and 7 of which are considered footnote disclosures. ${ }^{40}$ The 39 line items are presented at the end of this section.

Our measure is mathematically defined in equation (1) as outlined in section 3.2.2. We provide a simple numerical example here. Assume a given industry in a given investee country has ten firms. Two of those firms are very large and share many characteristics with public peer firms, such as placing public corporate debt and having institutional investors (for instance, private equity firms). These two firms exhibit high disclosure granularity, enabling BvD to collect all 39 financial statements based on the firms' comprehensive annual reports with all necessary footnote information that often exceed 100 pages. On the other hand, three other firms are mid-sized and disclose basic balance sheet information and some P\&L items (e.g., only 18 items in total). Finally, the remaining five firms in the same industry are small and benefit from partial exemptions according domestic reporting regulations such that BvD does not observe a full set of financial statements. For these firms, only one balance sheet item (total assets) is available for this specific investee-industry-year, our private firm transparency measure would have the value of 0.35 calculated as follows:

$$
\text { Trans. \% FS Items (Private) }=\frac{39 * 2+18 * 3+1 * 5}{39 * 10}=\frac{137}{390}=0.35
$$

We also note $\mathrm{BvD}$ is considered to be the industry leader in collecting, standardizing and disseminating company information, in particular of private firms around to world. BvD's dominance in the business of providing data to investors mean that it likely closely mimics the information availability for investors. Specifically, BvD regularly wins awards for providing the "best entity data solution" through its Orbis database in particular The Orbis database is recognized with this award because it enables its commercial clients to make "faster decisions (..) amid the continuing economic uncertainty" (https://www.businesswire.com/news/home/20201210005488/en/). Because BvD is the industry leader with its Orbis database, Moody's Analytics decided to acquire BvD in 2017 for more than USD \$3.5 billion (https://www.ft.com/content/e0a39012-395c-11e7-ac89-b01cc67cfeec, Moody's). When justifying the purchase price and describing their newly acquired business, Moody's state in their 2018 annual report that "Bureau van Dijk aggregates, standardizes and distributes one of the world's most extensive private company datasets. We are very pleased to be able to add this successful and highly complementary business, which builds on Moody's role as a global provider of credit risk measures and analytical insight."

\footnotetext{
${ }^{40}$ There are more than 39 variables available in the Orbis database. However, these variables are constructed by BvD based on the information of the collected data that were classified according to the 39 financial statement items (for instance, the EBITDA variable is EBIT plus depreciation, or the Cash Flow variable is EBT plus depreciation).
} 


\section{Appendix A. Measurement of Private Firm Transparency [Continued]}

The 39 Standardized Financial Statement Items Observable in Orbis

\section{Balance Sheet Items}

Fixed Assets

Fixed Assets: Intangibles

Fixed Assets: Tangibles

Fixed Assets: Other

Current Assets

Current Assets: Stock

Current Assets: Receivables

Current Assets: Other

Cash

Total Assets

Income Statement $(P \& L)$ Items

Revenue

Costs of Goods Sold (COGS)

Gross Profit

Operating Expenses

Earnings Before Interest and Taxes (EBIT)

Financial Revenue

Financial Expenses

Earnings Before Taxes (EBT)

Tax Expense

Net Income

\author{
Equity Funds \\ Equity Capital \\ Equity Funds Other \\ Noncurrent Liabilities \\ Noncurrent Liabilities: Long-term Debt \\ Noncurrent Liabilities: Other \\ Current Liabilities \\ Current Liabilities: Loans \\ Current Liabilities: Creditors \\ Current Liabilities: Other \\ Provisions \\ Total Equity and Liabilities
}

Footnote Disclosure Items

Number Employees

Export Revenue

Labor Expenses

Material Expenses

Depreciation \& Amortization

Interest Expense

R\&D Expense 
Appendix B. Variables Definitions

\begin{tabular}{|c|c|c|}
\hline Name & Definition & Source \\
\hline \multicolumn{3}{|l|}{ Dependent Variables } \\
\hline Log. FPI Equity & $\begin{array}{l}\text { Natural log of one plus foreign portfolio investments } \\
\text { in equity (i.e., FPI Equity). FPI Equity is defined as } \\
\text { investment positions in public equity of firms in a } \\
\text { given investee-industry-year held by investors from } \\
\text { around the world as developed by Coppola, Maggiori, } \\
\text { Neiman, and Schreger (2021). Positions are in USD } \\
\text { millions at the end of December. }\end{array}$ & GCAP \\
\hline Log. Number of M\&A Deals (private) & $\begin{array}{l}\text { Natural log of the number of M\&A transactions with } \\
\text { private target firms and official deal completion dates } \\
\text { within the two following years in a given investee- } \\
\text { industry acquired by foreign investors domiciled in a } \\
\text { given investor country industry. }\end{array}$ & BvD Zephyr \\
\hline Log. Number of M\&A Deals (public) & $\begin{array}{l}\text { Natural log of the number of M\&A transactions with } \\
\text { public target firms and official deal completion dates } \\
\text { within the two following years in a given investee- } \\
\text { industry acquired by foreign investors in a given } \\
\text { investor country industry. }\end{array}$ & BvD Zephyr \\
\hline Log. M\&A Deal Value (private) & $\begin{array}{l}\text { Natural log of the sum of total transaction values (set } \\
\text { to } 0 \text { if undisclosed) of private target firms with official } \\
\text { deal completion dates within the two following years } \\
\text { in a given investee-industry acquired by foreign } \\
\text { investors in a given investor country industry. }\end{array}$ & BvD Zephyr \\
\hline Log. M\&A Deal Value (public) & $\begin{array}{l}\text { Natural log of the sum of total transaction values (set } \\
\text { to } 0 \text { if undisclosed) of public target firms with official } \\
\text { deal completion dates within the two following years } \\
\text { in a given investee-industry acquired by foreign } \\
\text { investors in a given investor country industry. }\end{array}$ & BvD Zephyr \\
\hline Log. M\&A Revenue (private) & $\begin{array}{l}\text { Natural log of the sum of revenues of private target } \\
\text { firms with official deal completion dates within the } \\
\text { two following years acquired by foreign investors in a } \\
\text { given investor country industry. }\end{array}$ & BvD Zephyr \\
\hline Log. M\&A Revenue (public) & $\begin{array}{l}\text { Natural log of the sum of revenues of private target } \\
\text { firms with official deal completion dates within the } \\
\text { two following years public target firms acquired by } \\
\text { foreign investors in a given investor country industry. }\end{array}$ & BvD Zephyr \\
\hline Log. Number of VC Deals & $\begin{array}{l}\text { Natural log of the number of VC transactions with } \\
\text { private target firms and official deal completion dates } \\
\text { within the two following years in a given investee- } \\
\text { industry funded by foreign investors in a given } \\
\text { investor country industry. }\end{array}$ & BvD Zephyr \\
\hline Log. VC Deal Value & $\begin{array}{l}\text { Natural log of the sum of total transaction values (set } \\
\text { to } 0 \text { if undisclosed) of VC transactions with official } \\
\text { deal completion dates within the two following years } \\
\text { in a given investee-industry funded by foreign } \\
\text { investors in a given investor country industry. }\end{array}$ & BvD Zephyr \\
\hline Log. VC Revenue & $\begin{array}{l}\text { Natural log of the sum of revenues of private target } \\
\text { firms in VC transactions with official deal completion } \\
\text { dates within the two following years funded by } \\
\text { foreign investors domiciled in a given investor } \\
\text { country industry. }\end{array}$ & BvD Zephyr \\
\hline Log. FPI Equity (intensive margin) & Non-zero Log. FPI Equity. & GCAP \\
\hline
\end{tabular}




\begin{tabular}{|c|c|c|}
\hline Log. FPI Equity (tax haven) & $\begin{array}{l}\text { Natural log of one plus FPI Equity, same as Log. FPI } \\
\text { Equity but only foreign portfolio investments made to } \\
\text { entities in tax havens are reassigned to the } \\
\text { incorporation country of the entities' parent (whereas } \\
\text { Log. FPI Equity reassigns to the incorporation country } \\
\text { of the parent for investments made to both tax havens } \\
\text { and non-tax havens). }\end{array}$ & GCAP \\
\hline Log. FPI Equity (residency) & $\begin{array}{l}\text { Natural log of one plus FPI Equity, same as Log. FPI } \\
\text { Equity but defines investee countries based on } \\
\text { "residency" (i.e., the incorporation country of the } \\
\text { issuing entity) of the immediate issuer of equity not } \\
\text { the incorporation country of the parent. }\end{array}$ & GCAP \\
\hline Private Firm M\&A Acquisition (0/1) & $\begin{array}{l}\text { An indicator taking on the value of } 1 \text { in the year a } \\
\text { private firm is acquired by a foreign investor. }\end{array}$ & BvD Zephyr \\
\hline \multicolumn{3}{|l|}{ Independent Variables } \\
\hline Transp. \% FS Items (private) & $\begin{array}{l}\text { Private firm financial transparency defined as the } \\
\text { number of non-missing financial statement line items } \\
\text { disclosed by private firms in each investee-industry- } \\
\text { year, divided by the total number of line items that } \\
\text { these private firms can hypothetically disclose } \\
\text { conditional on each private firm preparing and } \\
\text { publishing financial statements (as proxied by the } \\
\text { observability of at least one financial statement item). } \\
\text { The hypothetical full disclosure is based on } 39 \\
\text { standardized financial statement items. }\end{array}$ & BvD Orbis \\
\hline Transp. \% FS Items (public) & $\begin{array}{l}\text { Public firm financial transparency defined as the } \\
\text { number of non-missing financial statement line items } \\
\text { disclosed by public firms in each investee-industry- } \\
\text { year, divided by the total number of line items that } \\
\text { these public firms can hypothetically disclose. The } \\
\text { hypothetical full disclosure is based on } 39 \\
\text { standardized financial statement items. }\end{array}$ & BvD Orbis \\
\hline Transp. \% BS Items (private) & $\begin{array}{l}\text { The number of non-missing balance sheet line items } \\
\text { disclosed by private firms in each investee-industry- } \\
\text { year, divided by the total number of balance sheet line } \\
\text { items that private firms can hypothetically disclose. }\end{array}$ & BvD Orbis \\
\hline Transp. \% BS Items (public) & $\begin{array}{l}\text { The number of non-missing balance sheet line items } \\
\text { disclosed by public firms in each investee-industry- } \\
\text { year, divided by the total number of balance sheet line } \\
\text { items that public firms can hypothetically disclose. }\end{array}$ & BvD Orbis \\
\hline Transp. \% PL Items (private) & $\begin{array}{l}\text { The number of non-missing profit and loss statement } \\
\text { (i.e., income statement) line items disclosed by private } \\
\text { firms in each investee-industry-year, divided by the } \\
\text { total number of profit and loss statement line items } \\
\text { that private firms can hypothetically disclose. }\end{array}$ & BvD Orbis \\
\hline Transp. \% PL Items (public) & $\begin{array}{l}\text { The number of non-missing profit and loss statement } \\
\text { (i.e., income statement) line items disclosed by public } \\
\text { firms in each investee-industry-year, divided by the } \\
\text { total number of profit and loss statement line items } \\
\text { that public firms can hypothetically disclose }\end{array}$ & BvD Orbis \\
\hline Transp. \% Footnote Items (private) & $\begin{array}{l}\text { The number of non-missing numerical footnote items } \\
\text { disclosed by private firms in each investee-industry- } \\
\text { year, divided by the total number of footnote items } \\
\text { that private firms can hypothetically disclose. }\end{array}$ & BvD Orbis \\
\hline
\end{tabular}




\begin{tabular}{|c|c|c|}
\hline Transp. \% Footnote Items (public) & $\begin{array}{l}\text { The number of non-missing numerical footnote items } \\
\text { disclosed by public firms in each investee-industry- } \\
\text { year, divided by the total number of footnote items } \\
\text { that public firms can hypothetically disclose. }\end{array}$ & BvD Orbis \\
\hline Firm Transp. \% FS Items (private) & $\begin{array}{l}\text { A firm-specific version of our private firm } \\
\text { transparency measure. It is defined as the number of } \\
\text { non-missing financial statement line items disclosed } \\
\text { by an individual private target firm in a given year, } \\
\text { divided by the } 39 \text { line items that the firm can } \\
\text { hypothetically disclose. }\end{array}$ & BvD Orbis \\
\hline Log. No. Public Firms & $\begin{array}{l}\text { Natural log of the total number of private firms in a } \\
\text { given investee-industry-year. }\end{array}$ & BvD Orbis \\
\hline Log. No. Private Firms & $\begin{array}{l}\text { Natural log of the total number of public firms in a } \\
\text { given investee-industry-year. }\end{array}$ & BvD Orbis \\
\hline Log. Median Size (Total Assets) & $\begin{array}{l}\text { Natural log of the median firm's total assets, with the } \\
\text { median calculated within each investee-industry-year } \\
\text { cell to capture firm size distributions over time. }\end{array}$ & BvD Orbis \\
\hline$R O A$ & $\begin{array}{l}\text { Average of private firms' and public firms' return on } \\
\text { assets (earnings before interest and taxes divided by } \\
\text { total assets) in a given investee-industry-year. }\end{array}$ & BvD Orbis \\
\hline Revenue Growth & $\begin{array}{l}\text { Average of private firms' and public firms' annual } \\
\text { growth rates in a given investee-industry-year. }\end{array}$ & BvD Orbis \\
\hline Transp. Log. Total FS Items (private) & $\begin{array}{l}\text { Total number of line item disclosures of private firms } \\
\text { in a given investee-industry-year. }\end{array}$ & BvD Orbis \\
\hline $\begin{array}{l}\text { Transp. \% FS Items Divided by } \\
\text { No. Firms (private) }\end{array}$ & $\begin{array}{l}\text { Total number of line item disclosures divided by the } \\
\text { number of private firms. }\end{array}$ & BvD Orbis \\
\hline Transp. Total FS Items Quintile & Quintile values of Transp. \% FS Items (private). & BvD Orbis \\
\hline \multicolumn{3}{|l|}{ Cross-sectional Variables } \\
\hline Capital Control & $\begin{array}{l}\text { An indicator variable equal to } 1 \text { if the product of } \\
\text { investor country's capital control index and investee } \\
\text { country's capital control index - as developed by } \\
\text { Fernández et al. (2016) - is in the top decile within } \\
\text { each investee subsample, and 0, otherwise. }\end{array}$ & $\begin{array}{l}\text { Fernández et al. } \\
\text { (2016). }\end{array}$ \\
\hline Currency Appreciation & $\begin{array}{l}\text { An indicator variable equal to } 1 \text { if the percentage } \\
\text { increase of the investee country's annual real effective } \\
\text { exchange rate is in the top decile within each investee } \\
\text { subsample, and } 0 \text {, otherwise. }\end{array}$ & $\begin{array}{l}\text { BvD EIU } \\
\text { Country Data }\end{array}$ \\
\hline Language Distance & $\begin{array}{l}\text { An indicator variable equal to } 1 \text { if the first principal } \\
\text { component of non-common official language, non- } \\
\text { common spoken language, and general language } \\
\text { differences using the Tree and the ASJP methods - as } \\
\text { developed by Mayer and Zignago ( } 2011 \text { ) and Melitz } \\
\text { and Toubal (2012) - is in the top decile for each } \\
\text { investee, and 0, otherwise. }\end{array}$ & CEPII \\
\hline Physical Distance & $\begin{array}{l}\text { An indicator variable equal to } 1 \text { if the first principal } \\
\text { component of the distance between the most } \\
\text { populated cities, the weighted distance - as developed } \\
\text { by Mayer and Zignago (2011) - and non-contiguity is } \\
\text { in the top decile for each investee, and 0, otherwise. }\end{array}$ & CEPII \\
\hline Post * BvD Office & $\begin{array}{l}\text { Indicator variable set equal to one in all years since } \\
\text { Bureau van Dijk has opened an office in a given } \\
\text { investee country; zero otherwise. }\end{array}$ & LinkedIn \\
\hline
\end{tabular}




\begin{tabular}{|c|c|c|}
\hline Post * Business Register & $\begin{array}{l}\text { Indicator variable set equal to one for years after the } \\
\text { electronic business register starts to operate in a given } \\
\text { investee country in a given year; zero otherwise. }\end{array}$ & $\begin{array}{l}\text { Breuer \& } \\
\text { Breuer }(2020)\end{array}$ \\
\hline \multicolumn{3}{|l|}{ Macro Variables } \\
\hline$F D I(\%$ of $G D P)$ & $\begin{array}{l}\text { Net foreign direct investment inflow divided by the } \\
\text { gross domestic product in a given investee country } \\
\text { and year. }\end{array}$ & World Bank \\
\hline Inflation & $\begin{array}{l}\text { Annual rate of inflation in a given investee country } \\
\text { and year. }\end{array}$ & World Bank \\
\hline Log. GDP & $\begin{array}{l}\text { Natural logarithm of the gross domestic product in a } \\
\text { given investee country and year. }\end{array}$ & World Bank \\
\hline Log. Population & $\begin{array}{l}\text { Natural logarithm of the total population count in a } \\
\text { given investee country and year. }\end{array}$ & World Bank \\
\hline \multicolumn{3}{|l|}{ Alternative Transparency Variables } \\
\hline Transp Log. Total FS Items (private) & $\begin{array}{l}\text { Unscaled private firm financial transparency defined } \\
\text { as the natural log of the number of non-missing } \\
\text { financial statement line items disclosed by private } \\
\text { firms in each investee-industry-year. }\end{array}$ & BvD Orbis \\
\hline $\begin{array}{l}\text { Transp Log. } \\
\text { Industry GDP }\end{array}$ & $\begin{array}{l}\text { Natural log of the ratio of the unscaled private firm } \\
\text { financial transparency (defined as the natural log of } \\
\text { the number of non-missing financial statement line } \\
\text { items disclosed by private firms in each investee- } \\
\text { industry-year) to industry-wide GDP. Industry-wide } \\
\text { GDP is measured in USD } 100 \mathrm{k} \text { in each investee- } \\
\text { industry-year by allocating country-wide total GDP to } \\
\text { a country's industries based on the relative number of } \\
\text { publicly listed firms in each industry. }\end{array}$ & $\begin{array}{l}\text { BvD Orbis, } \\
\text { World Bank }\end{array}$ \\
\hline Transp. (weighted) & $\begin{array}{l}\text { Market-share weighted version of our private firm } \\
\text { transparency measure. It is defined as the sum- } \\
\text { product of individual firm's number of non-missing } \\
\text { financial statement line items disclosed and revenues } \\
\text { divided by the product of } 39 \text { and the sum of all } \\
\text { industry firms' revenues ( } 39 \text { is the hypothetical full } \\
\text { disclosure given a firm discloses revenues and, thus, } \\
\text { produces financial statements). }\end{array}$ & BvD Orbis \\
\hline $\begin{array}{l}\text { Transp. \% FS Items Divided by No. } \\
\text { Firms (private) }\end{array}$ & $\begin{array}{l}\text { Total economy- scaled private firm financial } \\
\text { transparency defined as the number of non-missing } \\
\text { financial statement line items disclosed by private } \\
\text { firms in each investee-industry-year divided by the } \\
\text { total number of observable entities in the Orbis } \\
\text { database. }\end{array}$ & BvD Orbis \\
\hline Transp. Total FS Items Quintile & $\begin{array}{l}\text { Within-fiscal year quintiles of the number of non- } \\
\text { missing financial statement line items disclosed by } \\
\text { private firms in each investee-industry-year. }\end{array}$ & BvD Orbis \\
\hline
\end{tabular}




\section{Appendix C. Appendix Figures and Tables}

Figure A1. Residual Variation of Private Firm Transparency for the US, the UK, and Germany
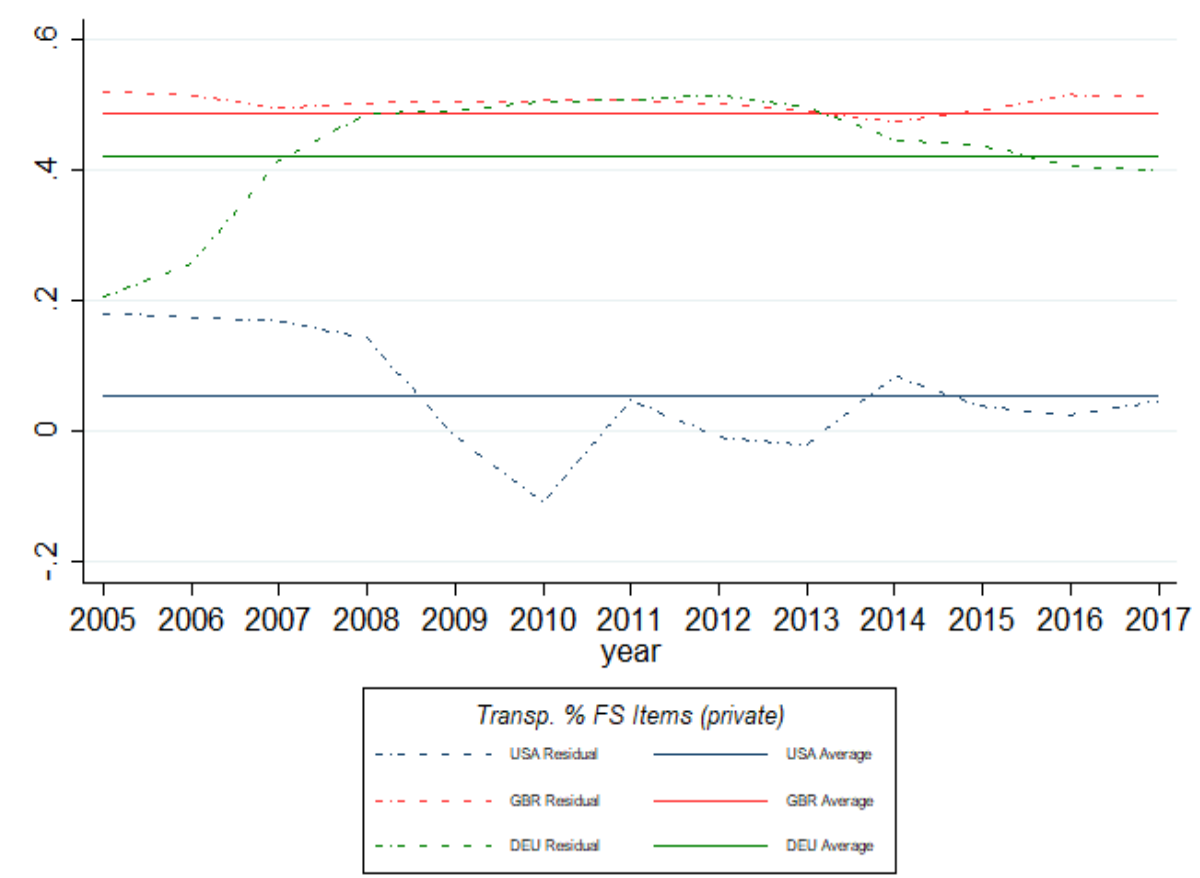

Notes: We plot the residual variation of our transparency measure (i.e., the residual obtained from regressing our transparency measure on a set of controls and the investor-investee-industry fixed effect). Germany shows negative residuals (i.e., values below the solid horizontal line that represents the average private firm transparency) prior to 2007 when the enforcement of private firms' disclosures was known to be relatively weak (e.g., Bernard (2016); Breuer, Leuz, Vanhaverbeke (2020); Bernard, Kaya, Wertz (2021) among others). After the major enforcement reform in 2007 as well as the implementation of the electronic business register in 2010, average residuals of our transparency measure becomes positive. In the US, we observe positive residuals before the financial crisis, consistent with more private firms preparing for listings on the stock market and thus providing more financial disclosures. During and after the financial crisis, residuals become negative potentially due to lower IPO activity. Finally, the steady variation for the UK is consistent with the UK's long history of mandating private firm disclosures combined with a strong and consistent level of enforcement of private firm disclosures (e.g., Napier (2010)). In sum, after controlling for various time-varying observables and investor-investee-industry fixed effects, the remaining variation (i.e., the residuals) seem to be driven by factors that are unlikely to fully explain a negative link between private firm transparency and foreign equity demand in a spurious way. 


\section{Appendix C. Appendix Figures and Tables [Continued]}

Table A1. Sample Construction for Main Sample

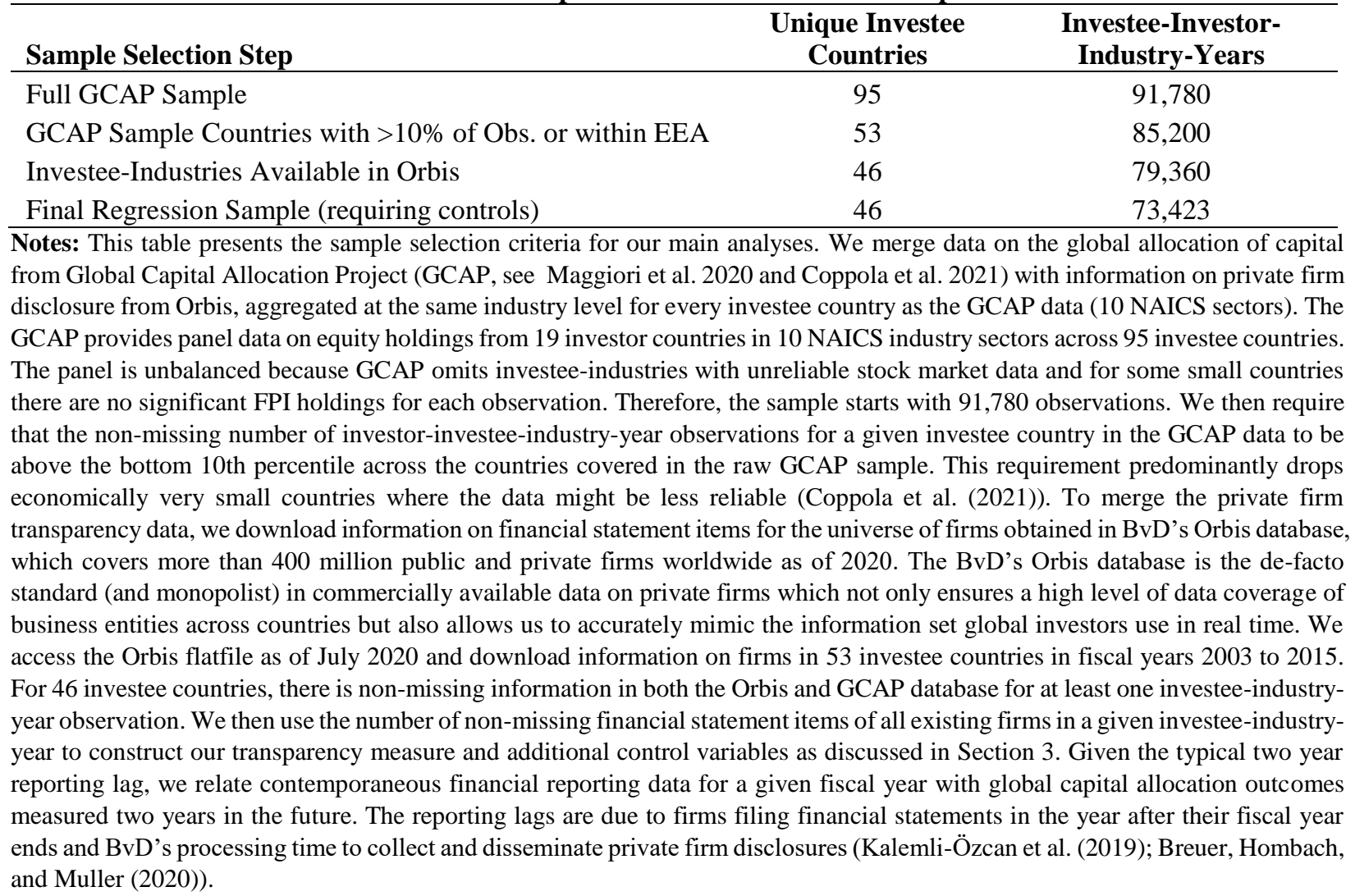




\section{Appendix C. Appendix Figures and Tables [Continued]}

Table A2. Sample Construction for M\&A and VC Transactions

\begin{tabular}{lcc}
\hline Sample Selection Step & $\begin{array}{c}\text { M\&A } \\
\text { Deals }\end{array}$ & $\begin{array}{c}\text { VC } \\
\text { Deals }\end{array}$ \\
\hline All completed deals in Zephyr database in 2005-2017 & 236,213 & 67,899 \\
$\ldots$ in investee countries with available target firm financial data in Orbis & 98,923 & 19,188 \\
\hline$\ldots$ by foreign acquirers & 23,794 & 2,773 \\
\hline & & \\
Private target firms & 20,302 & 2,657 \\
Public target firms & 3,492 & 116 \\
& & \\
Private target firms with deal value available & 8,182 & 2,050 \\
Public target firms with deal value available & 1,543 & 49 \\
\hline
\end{tabular}

Notes: This table presents the sample selection criteria that allows us to examine reallocation effects, i.e., whether private firm disclosures affect foreign capital allocation to private firms, we retrieve M\&A and venture capital (VC) transactions from BvD's Zephyr database (Table 5). Our M\&A sample starts with 236,213 completed (or completed assumed) corporate M\&A transactions around the world in the years 2005 to 2017 . Our VC data comprises 67,899 transactions in the same period. We then merge financial statement, industry classification, and legal information on the target firms from BvD's Orbis database. We limit the sample to transactions for which target firms are located in our 46 investee countries of interest and to transactions for which we observe the target firms' financial, industry, and legal information as well as the acquirers' country of incorporation. At this point, our sample includes 98,923 M\&A and 19,188 VC transactions. The latter steps allow us to a) differentiate between domestic and foreign investors, b) differentiate between private and public target firms that receive the foreign capital, c) measure the economic relevance of deals by target firm size, and d) assign the deals to specific investee-industry-years. 23,794 M\&A deals are made by foreign investors, with 20,302 acquisitions of private firms and 3,492 acquisitions of public firms. We observe deal values for 8,182 (1,543) acquisitions of private (public) firms. In the VC setting, we observe 2,773 transactions by foreign investors with capital being allocated to 2,657 (116) private (public) firms. Deal values are available in 2,050 (49) cases. We finally aggregate the deal data at the same level at which we conduct our tests on foreign equity holdings (i.e., 73,423investor-investee-industry-year level observations). 


\section{Appendix C. Appendix Figures and Tables [Continued]}

Table A3. Staggered BvD Office Opening Years

\begin{tabular}{|c|c|c|c|}
\hline \multirow[t]{2}{*}{ Investee Country } & \multirow{2}{*}{$\begin{array}{l}\text { BvD Office } \\
\text { Opening Year }\end{array}$} & \multicolumn{2}{|c|}{ Post BvD Office } \\
\hline & & Obs. & $\%$ of all Obs. \\
\hline Australia & 2013 & 890 & 2.3 \\
\hline Austria & 2013 & 690 & 1.8 \\
\hline Belgium & 1987 & 2,050 & 5.4 \\
\hline Bermuda & & 0 & 0.0 \\
\hline Brazil & 2013 & 860 & 2.3 \\
\hline Canada & & 0 & 0.0 \\
\hline Cayman Islands & & 0 & 0.0 \\
\hline China & 2008 & 1,880 & 4.9 \\
\hline Croatia & & 0 & 0.0 \\
\hline Cyprus & & 0 & 0.0 \\
\hline Czech Republic & & 0 & 0.0 \\
\hline Denmark & 2008 & 1,680 & 4.4 \\
\hline Estonia & & 0 & 0.0 \\
\hline Finland & & 0 & 0.0 \\
\hline France & 1996 & 2,350 & 6.2 \\
\hline Germany & 1991 & 2,350 & 6.2 \\
\hline Greece & & 0 & 0.0 \\
\hline Hong Kong & 2016 & 270 & 0.7 \\
\hline Hungary & & 0 & 0.0 \\
\hline Iceland & & 0 & 0.0 \\
\hline India & & 0 & 0.0 \\
\hline Ireland & & 0 & 0.0 \\
\hline Italy & 2000 & 2,350 & 6.2 \\
\hline Japan & 1994 & 2,350 & 6.2 \\
\hline Latvia & & 0 & 0.0 \\
\hline Lithuania & & 0 & 0.0 \\
\hline Luxembourg & & 0 & 0.0 \\
\hline Malta & & 0 & 0.0 \\
\hline Mexico & 2010 & 1,310 & 3.4 \\
\hline Netherlands & 2004 & 2,350 & 6.2 \\
\hline Norway & & 0 & 0.0 \\
\hline Poland & & 0 & 0.0 \\
\hline Portugal & & 0 & 0.0 \\
\hline Romania & & 0 & 0.0 \\
\hline Russia & 2008 & 1,460 & 3.8 \\
\hline Slovak Republic & 2012 & 650 & 1.7 \\
\hline Slovenia & & 0 & 0.0 \\
\hline South Africa & 2008 & 1,280 & 3.4 \\
\hline South Korea & 2007 & 2,000 & 5.2 \\
\hline Spain & 1996 & 2,350 & 6.2 \\
\hline Sweden & 2007 & 2,020 & 5.3 \\
\hline Switzerland & 1995 & 2,350 & 6.2 \\
\hline Taiwan & & 0 & 0.0 \\
\hline Turkey & & 0 & 0.0 \\
\hline United Kingdom & 1994 & 2,350 & 6.2 \\
\hline United States & 1994 & 2,350 & 6.2 \\
\hline
\end{tabular}

Notes: This table provides the BvD office opening years in each investee country. To obtain BvD office opening data, we first identify the existence of a local BvD office in each investee country using BvD's website. We then obtain the office opening years by a manually searching the LinkedIn profiles of management-level employees and find the first observable start date among these employees. If we do not find exact opening dates for the management-level employees, we use local employees' earliest start date of their job at BvD. 


\section{Appendix C. Appendix Figures and Tables [Continued]}

Table A4. Determinants of BvD Office Openings

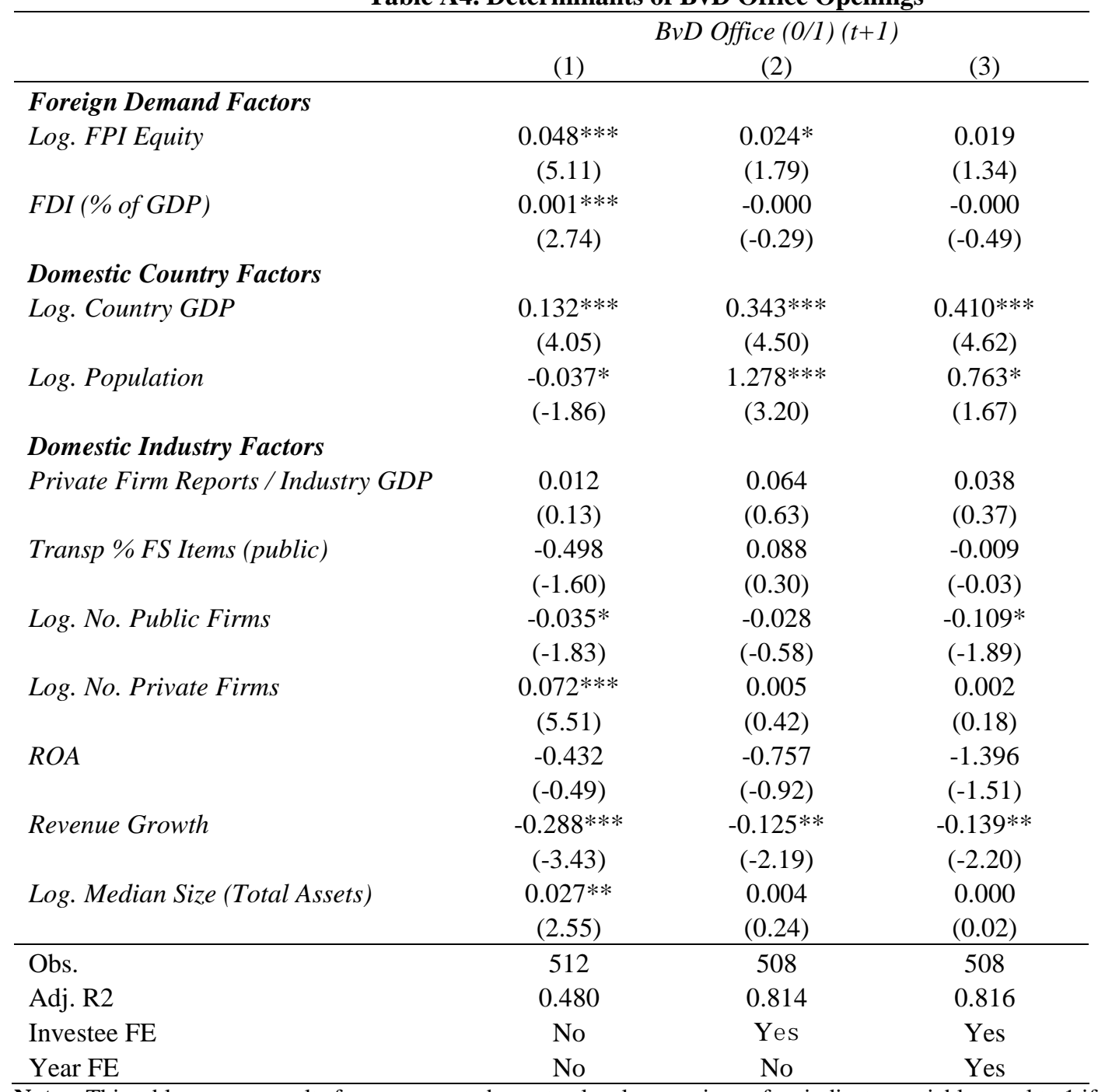

Notes: This table present results from aggregated country-level regressions of an indicator variable equal to 1 if BvD has an office location in a given investee-country-year (BvD Office (0/1)) in the following year on foreign and domestic investee country factors. Specifically, we include lagged demand for public equity and lagged foreign direct investments as foreign demand factors and lagged control variables and country-level macroeconomic factors as domestic factors. 


\section{Appendix C. Appendix Figures and Tables [Continued]}

Table A5. Staggered Electronic Business Register Implementation Year

\begin{tabular}{|c|c|c|c|}
\hline \multirow[t]{2}{*}{ Investee Country } & \multirow{2}{*}{$\begin{array}{l}\text { Business Register } \\
\text { Implementation Year }\end{array}$} & \multicolumn{2}{|c|}{ Post Business Register } \\
\hline & & Obs. & $\%$ of all Obs. \\
\hline Australia & & 0 & 0.0 \\
\hline Austria & 2001 & 1,740 & 5.6 \\
\hline Belgium & 2008 & 1,530 & 5.0 \\
\hline Bermuda & & 0 & 0.0 \\
\hline Brazil & & 0 & 0.0 \\
\hline Canada & & 0 & 0.0 \\
\hline Cayman Islands & & 0 & 0.0 \\
\hline China & & 0 & 0.0 \\
\hline Croatia & 2008 & 450 & 1.5 \\
\hline Cyprus & & 0 & 0.0 \\
\hline Czech Republic & 2007 & 360 & 1.2 \\
\hline Denmark & 1999 & 2,100 & 6.8 \\
\hline Estonia & 2000 & 750 & 2.4 \\
\hline Finland & 2010 & 1,110 & 3.6 \\
\hline France & 2001 & 2,350 & 7.6 \\
\hline Germany & 2010 & 1,330 & 4.3 \\
\hline Greece & 2011 & 690 & 2.2 \\
\hline Hong Kong & & 0 & 0.0 \\
\hline Hungary & 2009 & 680 & 2.2 \\
\hline Iceland & & 0 & 0.0 \\
\hline India & & 0 & 0.0 \\
\hline Ireland & 2004 & 2,260 & 7.3 \\
\hline Italy & & 0 & 0.0 \\
\hline Japan & & 0 & 0.0 \\
\hline Latvia & & 0 & 0.0 \\
\hline Lithuania & & 0 & 0.0 \\
\hline Luxembourg & 2007 & 1,850 & 6.0 \\
\hline Malta & & 0 & 0.0 \\
\hline Mexico & & 0 & 0.0 \\
\hline Netherlands & 2006 & 2,050 & 6.6 \\
\hline Norway & 2007 & 1,690 & 5.5 \\
\hline Poland & 2018 & 0 & 0.0 \\
\hline Portugal & 2007 & 1,290 & 4.2 \\
\hline Romania & 2010 & 480 & 1.6 \\
\hline Russia & & 0 & 0.0 \\
\hline Slovak Republic & 2014 & 330 & 1.1 \\
\hline Slovenia & 2004 & 1,300 & 4.2 \\
\hline South Africa & & 0 & 0.0 \\
\hline South Korea & & 0 & 0.0 \\
\hline Spain & 1999 & 2,350 & 7.6 \\
\hline Sweden & 2000 & 2,320 & 7.5 \\
\hline Switzerland & & 0 & 0.0 \\
\hline Taiwan & & 0 & 0.0 \\
\hline Turkey & & 0 & 0.0 \\
\hline United Kingdom & 2007 & 1,880 & 6.1 \\
\hline United States & & 0 & 0.0 \\
\hline
\end{tabular}

Notes: This table provides business register implementation years in each European investee country. Business register implementation dates are from Breuer and Breuer (2020). 